University of Wollongong

Research Online

Faculty of Engineering and Information

Faculty of Engineering and Information

Sciences - Papers: Part B

Sciences

2017

Impact of wastewater derived dissolved interfering compounds on growth, enzymatic activity and trace organic contaminant removal of white rot fungi

- A critical review

Muhammad Bilal Asif

University of Wollongong, mba409@uowmail.edu.au

Faisal I. Hai

University of Wollongong, faisal@uow.edu.au

Jingwei Hou

University of New South Wales

William E. Price

University of Wollongong, wprice@uow.edu.au

Long D. Nghiem

University of Wollongong, longn@uow.edu.au

Follow this and additional works at: https://ro.uow.edu.au/eispapers1

Part of the Engineering Commons, and the Science and Technology Studies Commons

Research Online is the open access institutional repository for the University of Wollongong. For further information contact the UOW Library: research-pubs@uow.edu.au 


\title{
Impact of wastewater derived dissolved interfering compounds on growth, enzymatic activity and trace organic contaminant removal of white rot fungi - $A$ critical review
}

\begin{abstract}
White-rot fungi (WRF) and their ligninolytic enzymes have been investigated for the removal of a broad spectrum of trace organic contaminants (TrOCs) mostly from synthetic wastewater in lab-scale experiments. Only a few studies have reported the efficiency of such systems for the removal of TrOCs from real wastewater. Wastewater derived organic and inorganic compounds can inhibit: (i) WRF growth and their enzyme production capacity; (ii) enzymatic activity of ligninolytic enzymes; and (iii) catalytic efficiency of both WRF and enzymes. It is observed that essential metals such as $\mathrm{Cu}, \mathrm{Mn}$ and Co at trace concertation (up to $1 \mathrm{mM}$ ) can improve the growth of WRF species, whereas non-essential metal such as $\mathrm{Pb}, \mathrm{Cd}$ and $\mathrm{Hg}$ at $1 \mathrm{mM}$ concentration can inhibit WRF growth and their enzyme production. In the case of purified enzymes, most of the tested metals at 1-5 mM concentration do not significantly inhibit the activity of laccases. Organic interfering compounds such as oxalic acid and ethylenediaminetetraacetic acid (EDTA) at $1 \mathrm{mM}$ concentration are potent inhibitors of WRF and their extracellular enzymes. However, inhibitory effects induced by interfering compounds are strongly influenced by the type of WRF species as well as experimental conditions (e.g., incubation time and TrOC type). In this review, mechanisms and factors governing the interactions of interfering compounds with WRF and their ligninolytic enzymes are reviewed and elucidated. In addition, the performance of WRF and their ligninolytic enzymes for the removal of TrOCs from synthetic and real wastewater is critically summarized.

Disciplines

Engineering | Science and Technology Studies

\section{Publication Details}

Asif, M. B., Hai, F. I., Hou, J., Price, W. E. \& Nghiem, L. D. (2017). Impact of wastewater derived dissolved interfering compounds on growth, enzymatic activity and trace organic contaminant removal of white rot fungi - A critical review. Journal of Environmental Management, 201 89-109.
\end{abstract}

This journal article is available at Research Online: https://ro.uow.edu.au/eispapers1/296 
Impact of wastewater derived dissolved interfering compounds on growth, enzymatic activity and trace organic contaminant removal of white rot fungi - a critical review

\section{(Journal of Environmental Management)}

Muhammad B. Asif ${ }^{a}$, Faisal I. Hai ${ }^{a} *$, Jingwei Hou ${ }^{b}$, William E. Price ${ }^{c}$, Long D. Nghiem $^{\text {a }}$

${ }^{a}$ Strategic Water Infrastructure Lab, School of Civil, Mining and Environmental Engineering, University of Wollongong (UOW), Wollongong, NSW 2522, Australia.

${ }^{\mathrm{b}}$ UNESCO Centre for Membrane Science and Technology, School of Chemical Engineering, University of New South Wales, Sydney, NSW 2052, Australia

${ }^{c}$ Strategic Water Infrastructure Lab, School of Chemistry, University of Wollongong (UOW), Wollongong, NSW 2522, Australia.

*Corresponding author: Faisal I. Hai (E-mail: faisal@ uow.edu.au; Ph: +61 2 42213054)

\section{Publication Details:}

Asif, M.B., Hai, F.I., Hou, J., Price, W.E., Nghiem, L.D. 2017. Impact of wastewater derived dissolved interfering compounds on growth, enzymatic activity and trace organic contaminant removal of white rot fungi - A critical review. Journal of Environmental Management, 201, 89-109. 


\section{Table of Contents}

\section{Introduction}

2. Properties and performance of WRF and their ligninolytic enzymes

3. Wastewater derived interfering compounds

4. Impacts on WRF growth and enzyme production

4.1. Impact on WRF growth

4.2. Growth inhibition mechanisms

4.3. Impacts on enzyme secretion capacity

4.4. Effect of WRF species and incubation time

4.5. WRF defense mechanisms

5. Impacts on purified extracellular enzymes

5.1. Impacts of inorganic interfering compounds on laccase activity

5.1.1. Metals with low impact

5.1.2. Metals with significant impact

5.1.3. Impacts of anions

5.2. Impacts of organic interfering compounds on laccase activity

5.3. Factors influencing the inhibition of laccase

5.3.1. Effects of laccase source

5.3.2. Effect of incubation time

5.3.3. Choice of metal salts to study the impact of constituent ions

5.3.4. Choice of substrate to monitor enzymatic activity

6. Impacts of organic and inorganic interfering compounds on TrOC removal

7. Treatment of real wastewater

8. Future research

9. Conclusion 


\section{Highlights:}

- Heavy metals such as $\mathrm{Cd}, \mathrm{Pb}$ and $\mathrm{Hg}$ inhibits WRF growth at even $<1 \mathrm{mM}$ concentration

- Interfering metals induce oxidative stress in WRF, leading to cell lysis

- Some organics cause competitive inhibition/ denaturation of WRF enzyme (laccase)

- WRF species and interfering metal/organics concentration govern TrOC removal

- Some interfering compounds may affect enzymatic activity but not TrOC and vice versa 


\begin{abstract}
:
White-rot fungi (WRF) and their ligninolytic enzymes have been investigated to remove a broad spectrum of TrOCs mostly from synthetic wastewater in lab-scale experiments. Only a few studies have reported the efficiency of such systems for the removal of TrOCs from real wastewater. Wastewater derived organic and inorganic compounds can inhibit: (i) WRF growth and their enzyme production capacity; (ii) enzymatic activity of ligninolytic enzymes; and (iii) catalytic efficiency of both WRF and enzymes. It is observed that essential metals such as $\mathrm{Cu}, \mathrm{Mn}$ and $\mathrm{Co}$ at trace concertation (up to $1 \mathrm{mM}$ ) can improve the growth of WRF species, whereas non-essential metal such as $\mathrm{Pb}, \mathrm{Cd}$ and $\mathrm{Hg}$ at $1 \mathrm{mM}$ concentration can inhibit WRF growth and their enzyme production. In the case of purified enzymes, most of the tested metals at 1-5 $\mathrm{mM}$ concentration do not significantly inhibit the activity of laccases. Organic interfering compounds such as oxalic acid and ethylenediaminetetraacetic acid (EDTA) at $1 \mathrm{mM}$ concentration are potent inhibitors of WRF and their extracellular enzymes. However, inhibitory effects induced by interfering compounds are strongly influenced by the type of WRF species as well as experimental conditions (e.g. incubation time and TrOC type). In this review, mechanisms and factors governing the interactions of interfering compounds with WRF and their ligninolytic enzymes are reviewed and elucidated. In addition, the performance of WRF and their ligninolytic enzymes for the removal of TrOCs from synthetic and real wastewater is critically summarized.
\end{abstract}

Keywords: Trace organic contaminants (TrOCs); White-rot fungi (WRF); Metal salts; Organic solvents; Surfactant; Inhibitory mechanisms. 


\section{Introduction}

White-rot fungi (WRF) are a type of fungus that is known to degrade lignin, a class of complex natural organic polymers found in the cell wall of plants, by using their extracellular enzymatic system, called as ligninolytic enzymes (Bugg et al., 2011; Rouches et al., 2016). WRF and their ligninolytic enzymes have also been studied for the treatment of a variety of recalcitrant compounds such as polycyclic aromatic hydrocarbons, dyes, and chlorophenols (Hai et al., 2007; Yang et al., 2013b; Zhang et al., 2016). In particular, removal of trace organic contaminants (TrOCs) using WRF or their extracellular enzymes has gained much attention over the last decade (Kim and Nicell, 2006a; Nguyen et al., 2015; Tran et al., 2010). TrOCs such as pharmaceuticals, personal care products, industrial chemicals and steroid hormones have been commonly detected in municipal wastewater and surface water bodies. Their occurrence in environmental systems can be harmful to aquatic ecosystem and human health even at trace concentrations (Gavrilescu et al., 2015; Luo et al., 2014).

Whole-cell WRF and their ligninolytic enzymes have been reported to efficiently remove a wide range of TrOCs such as pharmaceuticals (e.g. ibuprofen, ketoprofen and diclofenac), personal care products (e.g. triclosan and oxybenzone) and steroid hormones (Marco-Urrea et al., 2010; Nguyen et al., 2014a; Nguyen et al., 2015; Yang et al., 2013a). Moreover, a number of performance influencing factors for such treatment systems have been identified. These factors include physicochemical properties of TrOCs, type of WRF species and their individual ligninolytic extracellular enzymes as well as culture medium and environmental conditions (Gao et al., 2010; Yang et al., 2013b). With a few exceptions, studies investigating the removal of TrOCs by whole-cell WRF or their ligninolytic enzymes used synthetic wastewater matrix containing a mixture of a few TrOCs (Marco-Urrea et al., 2009; Rodarte-Morales et al., 2011). However, the performance of whole-cell WRF or enzyme based treatment systems operated under controlled conditions may not reflect the true picture of their ability to treat municipal or industrial wastewater. 
Physicochemical properties of real wastewater are diverse. Real wastewater matrix contains different dissolved organic and inorganic interfering compounds. These interfering compounds can affect the growth of WRF species and can inactivate extracellular enzymes, consequently inhibiting their catalytic efficiency (Kim and Nicell, 2006c; Mutlu et al., 2014; Stajić et al., 2013). Depending on their concentration and the type of WRF species, inorganic interfering compounds such as $\mathrm{PbCl}_{2}, \mathrm{CdCl}_{2}$ and $\mathrm{HgCl}_{2}$ have been reported to inhibit the growth and enzyme secretion capacity of WRF. Exposure of WRF to interfering compounds could cause DNA damage, protein denaturation and cell lysis (Bhattacharya et al., 2014; Chen et al., 2014). Similarly, inhibition of the activity of extracellular enzymes has also been observed following the exposure of extracellular enzymes to different concentrations of organic interfering compounds such as oxalic acid and organic solvents (Kumar et al., 2012; RamírezCavazos et al., 2014). Therefore, impacts of interfering compounds on WRF and ligninolytic enzymes should be studied for an in-depth understating of their inhibitory mechanisms.

Many reviews related to WRF and their ligninolytic enzymes have been published over the last few years. (Asif et al., 2017; Gao et al., 2010; Kües, 2015; Rodgers et al., 2010; Tortella et al., 2015; Yang et al., 2013b). However, impacts of wastewater derived interfering compounds on the growth of WRF and their enzyme production capacity as well as on the stability and catalytic efficiency of extracellular enzymes have not been reviewed systematically. This review aims to critically evaluate the impacts of dissolved organic and inorganic interfering impurities on WRF growth and enzymatic activity and TrOC removal. In addition, the inhibitory mechanisms and influencing factors (e.g. effects of WRF species and incubation time) are critically discussed. Efficacy of WRF and their ligninolytic enzymes for the removal of TrOCs from synthetic and real wastewater is also reviewed to provide a general overview. Directions for future research are also outlined.

\section{Properties and performance of WRF and their ligninolytic enzymes}

WRF species degrade recalcitrant compounds including TrOCs by using their intracellular or extracellular enzymes (Lloret et al., 2012; Yang et al., 2013b). In order to understand the impacts of wastewater 
derived interfering compounds on the growth and enzymatic activity of WRF, it is vital to understand the key features of WRF and their enzymatic systems. This section provides this important background information concisely.

The key features of WRF that make them an attractive treatment option for TrOC removal include but are not limited to (i) the non-specificity and non-selectivity of their enzyme systems, enabling them to degrade complex individual and mixture of pollutants; (ii) the secretion of extracellular enzymes, enabling them to degrade pollutants with low water solubility; (iii) the ability of their plasma membranedependent redox system to degrade pollutants in a nutrient deficient reaction mixture over a wide range of $\mathrm{pH}$; and (iv) the ability of intracellular enzyme to degrade some pollutants (Pointing, 2001; RodríguezCouto, 2016; Rouches et al., 2016):. Depending on growth medium and culture conditions as well as on the type of WRF species/strains, WRF can secrete four different ligninolytic enzymes namely laccase, lignin peroxidase (LiP), manganese peroxidase $(\mathrm{MnP})$ and versatile peroxidase (VP). In addition, cytochrome P450 monooxygenases, a group of intracellular enzymes, have also been reported to play a vital role in the degradation of TrOCs via hydroxylation, dehalogenation and heteroatom oxygenation mechanisms (Dashtban et al., 2010; Golan-Rozen et al., 2011; Yang et al., 2013b).

Characteristics of ligninolytic extracellular enzymes such as molecular mass, isoelectric point and redox potential are outlined in Table 1. Stability and catalytic potential of ligninolytic enzymes may vary due to difference in their redox-potential as well as due to the extent of glycosylation. In general, enzymes having high redox-potential are favorable for enzyme catalyzed reactions (Dashtban et al., 2010; Fabbrini et al., 2002; Riva, 2006). Redox-potential of ligninolytic enzymes is as follows: LiP $>\mathrm{MnP}=\mathrm{VP}>$ laccase (Table 1).

Glycosylation, a complex enzymatic process, is responsible for the formation of biopolymers such as polynucleotides at the cellular level (Haltiwanger and Lowe, 2004; Jung et al., 2011). Glycosylation in extracellular enzymes can influence their shape, structure, composition and the formation of substrate binding sites as well as their properties such as redox-potential, enzymatic activity and catalytic potential 
(Sirim et al., 2011; Yang et al., 2015). Stability of enzymes tends to improve with the increase of glycosylation but it may not always improve the catalytic potential of an enzyme (Hamilton and Gerngross, 2007; Maestre-Reyna et al., 2015). Deglycosylation of extracellular enzymes has been observed to adversely affect the enzymatic activity, stability and catalytic potential of enzymes (Nagai et al., 1997; Vite-Vallejo et al., 2009; Yang et al., 2015). Notably, the catalytic potential or redox-potential of LiP is higher than other ligninolytic enzymes, possibly because the level of glycosylation in LiP is greater than other ligninolytic enzymes (Dashtban et al., 2010; Sigoillot et al., 2012). Isoelectric point is important to estimate the charge on fungal enzymes at different $\mathrm{pH}$ (Magner, 2013). Isoelectric point of ligninolytic enzymes mostly falls in acidic $\mathrm{pH}$ range i.e. 3-7, indicating that ligninolytic enzymes are negatively charged at $\mathrm{pH} \geq 7.0$ (Lu et al., 2017)

\section{[Table 1]}

WRF mediated removal of TrOCs involves secondary metabolism. In presence of an easily degradable substrate, WRF species produce ligninolytic enzymes that can degrade TrOCs (Yang et al., 2013a; Yang et al., 2013b). TrOC removal mechanisms by whole-cell WRF include biosorption onto fungal biomass as well as degradation by extracellular and intracellular enzymes, as depicted in Figure 1. However, the extent of TrOC removal in whole-cell fungal treatment systems may vary depending on the type of WRF species or even the strain (Yang et al., 2013b). An alternative to wholecell WRF treatment is the use of crude or purified enzymes, thus separating fungal growth and pollutant degradation steps (Spina and Varese, 2016). Among the WRF enzymes, laccases have predominantly been used compared to lignin peroxidases because laccases do not require a cofactor for the oxidation of recalcitrant pollutants and have demonstrated better stability than peroxidases (Ashe et al., 2016; Nguyen et al., 2014b; Riva, 2006; Wang et al., 2012).

\section{[Figure 1]}


Notably, wide variations in the removal of TrOCs by whole-cell WRF and laccase (crude/purified) can be observed depending on the physicochemical properties of the compounds, the experimental conditions and the type of WRF species and their ligninolytic enzymes (Figure 2). These factors governing the performance of WRF or laccase based treatment for TrOC removal have been critically reviewed (Asif et al., 2017; Yang et al., 2013b). The main focus of the current review is to elucidate and discuss the effects of wastewater derived interfering compounds on the growth and enzyme production capacity of WRF as well as on the activity and catalytic efficiency of extracellular enzymes.

\section{[Figure 2]}

\section{Wastewater derived interfering compounds}

Fungal/enzymatic bioreactors have mostly been studied for the treatment of synthetic wastewater spiked with TrOCs in absence of potential inhibiting compounds prevalent in real wastewater (Asif et al., 2017; Margot et al., 2015; Yang et al., 2013b). However, wastewater derived interfering compounds can affect the stability and catalytic efficiency of WRF and ligninolytic enzymes (Sadhasivam et al., 2008; Zeng et al., 2012). Interfering compounds can be divided into two categories, namely inorganic and organic compounds. Organic interfering compounds such as organic acids and solvents are used in different industrial processes, and hence are detected in industrial wastewater. For instance, phenol and $\mathcal{E}$-caprolactam are used as monomers for polymerization in plastic industries, while organic solvents such as methanol, ethanol and acetone are used in pharmaceutical as well as in resin manufacturing. Concentration of organic solvents in industrial wastewater can vary from 0.1-1\% w/w (Grodowska and Parczewski, 2010; Kim and Nicell, 2006a). Similarly, EDTA is used in fabric modification for dyeing and as an ingredient of bleaching powder (Riemenschneider and Tanifuji, 2000; Taxiarchou and Douni, 
2014). Citric acid is an active ingredient of pharmaceuticals, cosmetics, and food products (OECD, 2001; Roehr et al., 2008).

In municipal and industrial wastewater, inorganic interfering compounds comprise mainly of inorganic salts. Specific inhibitory effects of different cations and anions on WRF and ligninolytic enzymes have been reported (see Section 5.1). Concentration of cations commonly detected in wastewater varies from $2 \mu \mathrm{g} / \mathrm{L}$ to $200 \mathrm{mg} / \mathrm{L}$ (Supplementary data Table S2). For example, concentrations of common cations such as $\mathrm{Na}^{+}$and $\mathrm{Ca}^{+2}$ have been reported to be in the range $32-170 \mathrm{mg} / \mathrm{L}$, while trace concentrations $(1-10 \mu \mathrm{g} / \mathrm{L})$ of heavy metal cations such as $\mathrm{Cr}$, $\mathrm{Pb}, \mathrm{Zn}$ and As have been reported (Auriol et al., 2007; Carletti et al., 2008; Spina et al., 2015). Among interfering anions, a high concentration of chloride (240-1500 mg/L) can be expected in wastewater (Auriol et al., 2008; Mir-Tutusaus et al., 2016). The concentration of other anions such as fluoride, sulfate and cyanide can be in the range of 0.002-0.05 mM (Supplementary data Table S2). Since WRF and enzymatic treatment has the potential for the treatment of both municipal and industrial wastewater, a comprehensive literature survey was carried out to discuss and elucidate the inhibitory effects of aforementioned interfering compounds on the growth and activity of WRF and ligninolytic enzymes.

\section{Impacts of interfering compounds on WRF growth and enzyme production}

\subsection{Impact on WRF growth}

WRF can uptake heavy metals from their immediate environmental settings which could affect their metabolic processes. Impacts of heavy metals on WRF growth and their ability to produce extracellular enzymes have been investigated mostly from the viewpoint of WRF potential to uptake and/or remove heavy metals (Bayramoğlu and Arıca, 2008; Chen et al., 2012). Although heavy metals are generally toxic to WRF, some heavy metals such as $\mathrm{Cu}, \mathrm{Mn}, \mathrm{Fe}$ and $\mathrm{Co}$ at trace concentrations are essential for the 
growth of fungi. However, these essential metals can inhibit the growth of WRF at high concentrations. Heavy metals that are generally toxic to WRF include $\mathrm{Pb}, \mathrm{Cd}, \mathrm{Hg}$ and $\mathrm{Ag}$ (Baldrian, 2003; Baldrian et al., 2005; Bhattacharya et al., 2014; Gupta et al., 2016; Mutlu et al., 2014).

$\mathrm{Cd}, \mathrm{Pb}$ and $\mathrm{Hg}$ are the most toxic heavy metals for WRF (Bhattacharya et al., 2014; Hatvani and Mécs, 2003; Li et al., 2015; Wan et al., 2015; Zhang et al., 2015). For instance, severe inhibition ( $\geq 50 \%)$ of the growth of Lentinula edodes (Hatvani and Mécs, 2003), Trametes versicolor (Mutlu et al., 2014) and Phanerochaete chrysosporium (Li et al., 2015) has been reported at low concentrations of $\mathrm{HgCl}_{2}(0.015$ $\mathrm{mM}), \mathrm{CdCl}_{2}(0.05 \mathrm{mM})$ and $\mathrm{Pb}\left(\mathrm{NO}_{3}\right)_{2}(0.6 \mathrm{mM})$, respectively. On the other hand, essential heavy metals such as $\mathrm{Cu}, \mathrm{Mn}, \mathrm{Zn}$ and Co could slightly improve the growth of WRF. For instance, Bhattacharya et al. (2014) observed an $8 \%$ improvement in the growth of Pleurotus ostreatus in the presence of $5 \mathrm{mM}$ $\mathrm{CuSO}_{4}$. Similarly, Baldrian et al. (2005) reported a slight increase (2-5\%) in the growth of Pleurotus ostreatus due to the addition of $\mathrm{MnSO}_{4}$ at 1-10 mM. However, the growth of Lentinula edodes was inhibited by $50 \%$ in presence of $\mathrm{MnSO}_{4}$ only at a concentration of $3.1 \mathrm{mM}$ (Hatvani and Mécs, 2003), which suggests that the specific impact depends on both the type of salt and fungi.

Organic compounds such as ethylenediaminetetraacetic acid (EDTA), citric acid and organic solvents can be detected in industrial and municipal wastewater. These compounds may induce significant toxic effects in a number of aquatic species (OECD, 2001; Reaves, 2004; Roehr et al., 2008). For example, EDTA is used in dyeing processes, in silica analysis equipment and as an ingredient of bleaching powder (Riemenschneider and Tanifuji, 2000; Taxiarchou and Douni, 2014). EDTA was reported to reduce the population of green algae by $50 \%$ within $96 \mathrm{~h}$ of exposure even at a concentration of $0.01 \mathrm{mM}$ (Reaves, 2004). Similarly, citric acid, an active ingredient of pharmaceuticals, cosmetics, and food products, can reduce the population of fish (Lepomis macrochirus and Leuciscus idus) and crustaceans species by $50 \%$ at 2.3 and $0.9 \mathrm{mM}$, respectively (OECD, 2001; Roehr et al., 2008). Although the impacts of organic interfering compounds on WRF have not been investigated thoroughly, these compounds can be toxic to 
WRF species as well. Indeed, in a study by Bhattacharya et al. (2014), EDTA (5 mM) reduced the growth of Pleurotus ostreatus by $80 \%$.

\subsection{Growth inhibition mechanisms}

Recent studies show that the mechanisms of WRF growth inhibition by metals are similar to other microbes (Zeng et al., 2012; Zeng et al., 2015; Zhang et al., 2015). Possible mechanisms of inhibition due to metal-induced toxicity may include; (i) alteration in the morphology of fungal mycelium (Errasquin and Vazquez, 2003; Peña-Castro et al., 2004); (ii) inhibition of intracellular and extracellular proteins due to the denaturation of sulfhydryl groups (Hall, 2002; Kiyono et al., 2010); (iii) disruption in the formation

of cell wall by inhibiting $\mathrm{Ca}^{+2}$ dependent regulatory pathways which results in enhanced intercellular $\mathrm{Ca}^{+2}$ efflux (Poirier et al., 2008; Zeng et al., 2012); (iv) induction of oxidative stress due to the inactivation of enzymatic and non-enzymatic antioxidants such as thiols and peroxidases (Kim et al., 2013; Zhang et al., 2015); and (v) formation and accumulation of excessive reactive oxygen species (ROS) namely $\mathrm{O}^{-2}, \mathrm{OH}^{-1}$ and $\mathrm{H}_{2} \mathrm{O}_{2}$, causing severe damage to the cell structure (lipids and proteins) and nucleic acid (DNA and mRNA) as well as enzyme inactivation (Chen et al., 2014; Gupta et al., 2016; Zeng et al., 2012). Despite their potential inhibitory effects, ROS at low concentrations plays an important role in cellular signaling systems such as induction of mutagenic response (Valko et al., 2006; Wan et al., 2015). Impacts of heavy metals on WRF growth are systematically presented in Figure 3.

\section{[Figure 3]}

\subsection{Impacts on enzyme secretion capacity}

Metals may understandably affect WRF growth and enzymatic activity simultaneously, but may not be to the same extent. For instance, Mutlu et al. (2014) investigated the toxic stress of $\mathrm{CdCl}_{2}$ on the growth of Trametes versicolor as well as the production of laccase. They observed that the growth of Trametes versicolor was reduced by 40-60 \% in presence of $0.3-1.1 \mathrm{mM} \mathrm{CdCl}_{2}$, but the specific laccase activity i.e., activity per unit weight of biomass gradually increased (Mutlu et al., 2014). Therefore, it is important to 
observe both biomass growth and enzyme production in experiments focusing on the toxic effects of metals in order to develop a correlation between WRF growth inhibition and enzyme production. Surprisingly, only a few studies have reported both the change in WRF growth and enzyme activity (Hatvani and Mécs, 2003; Huang et al., 2010; Mutlu et al., 2014). For instance, Hatvani and Mécs (2003) investigated the impacts of nine heavy metals, including $\mathrm{Cd}, \mathrm{Cu}, \mathrm{Co}, \mathrm{Fe}, \mathrm{Hg}, \mathrm{Mn}, \mathrm{Ni}, \mathrm{Pb}$ and $\mathrm{Zn}$ over a range of $0.005-6 \mathrm{mM}$ separately, on the growth and enzyme production capacity of Lentinula edodes. They observed that the production of laccase increased in the presence of all heavy metals except Fe, while the production of $\mathrm{MnP}$ reduced in the presence of all heavy metals. This was accompanied by a reduction of growth of Lentinula edodes by 20\%, (Hatvani and Mécs, 2003). Similarly, Huang et al. (2010) reported that the growth of Phanerochaete chrysosporium (BKMF-1767) was reduced by 12 and $50 \%$ at $\mathrm{Pb}\left(\mathrm{NO}_{3}\right)_{2}$ concentrations of 0.09 and $1.2 \mathrm{mM}$, respectively, with a concomitant drop in specific LiP activity of 55 and $72 \%$. However, the specific MnP activity was not affected in any of the tested concentrations (Huang et al., 2010).

Increase in the production or activity of an extracellular enzyme such as laccase has been observed in the presence of essential metals such as $\mathrm{Cu}, \mathrm{Fe}, \mathrm{Mn}$, $\mathrm{Co}$ and $\mathrm{Zn}$. For instance, $\mathrm{CuSO}_{4}$ at $0.5-1 \mathrm{mM}$ concentration increased the production of laccases from Pleurotus ostreatus (Baldrian and Gabriel, 2002; Bhattacharya et al., 2014) and Lentinus polychrous (Khammuang et al., 2013). Enzymes are strongly regulated at the transcription level. $\mathrm{Cu}$ can enhance the transcription levels in WRF, thereby increasing the production of enzymes (Baldrian, 2003). Similarly, exposure of WRF to $\mathrm{ZnSO}_{4}(0.26 \mathrm{mM}), \mathrm{MnSO}_{4}$ $(2.4 \mathrm{mM})$ and $\mathrm{NiCl}_{2}(0.16 \mathrm{mM})$ increased the production of laccase from Lentinula edodes by 27,29 and 48\%, respectively (Hatvani and Mécs, 2003). On the other hand, non-essential metals can inhibit the enzyme production even at trace concentrations. For example, $0.0005 \mathrm{mM} \mathrm{CdCl}_{2}$ significantly reduced (>70\%) the production of laccase from Funalia trogii (Mutlu et al., 2014). Similarly, production of other extracellular enzymes, namely LiP and MnP, have been reported to be also affected. For instance, LiP and MnP production from Phanerochaete chrysosporium was inhibited by 49 and 30\%, respectively, at a 
$\mathrm{Pb}\left(\mathrm{NO}_{3}\right)_{2}$ concentration of $0.05 \mathrm{mM}$ (Zhang et al., 2015). Similarly, Chen et al. (2015) observed a linear decrease in the production of $\mathrm{LiP}$ and $\mathrm{MnP}$ from Phanerochaete chrysosporium when $\mathrm{CdCl}_{2}$ dose was increased from 0.1 to $0.5 \mathrm{mM}$. Notably all these studies (Bhattacharya et al., 2014; Chen et al., 2015; Zhang et al., 2015) reported only enzymatic activity, and not the change in biomass growth, which makes it difficult to assess the specific mode of impact on enzymatic activity.

In terms of the impact on intracellular enzymes of WRF, there is a strong body of evidence that $\mathrm{Pb}$ can inhibit a number of enzymatic antioxidants associated with cytochrome P450 (Matityahu et al., 2010). Heavy metals, particularly $\mathrm{Pb}$ and $\mathrm{Cd}$, may inhibit intracellular enzymes using two mechanisms (Kim et al., 2002; Sugiyama, 1992; Zhang et al., 2015); (i) Protein denaturation: heavy metals may inactivate $\delta$ aminolevulinic acid dehydratase which is an important enzyme for the synthesis of a prosthetic group of cytochrome P450 i.e., heme is; and (ii) Direct inhibition of cytochrome P450: heavy metals, particularly $\mathrm{Pb}$, may alter the conformation of phospholipids, causing lipid peroxidation and affecting the transport of electrons among microsomal cytochrome P450. Recently, Zhang et al. (2015) confirmed the inhibition of cytochrome $\mathrm{P} 450$ and cytochrome $\mathrm{P} 420$ in Phanerochaete chrysosporium by $\mathrm{Pb}$ and $\mathrm{Cd}$ separately over a range of $0.005-0.05 \mathrm{mM}$, but not beyond that. In fact they observed increased activity of cytochrome $\mathrm{P} 450$ and cytochrome $\mathrm{P} 420$ in presence of $\mathrm{Pb}$ or $\mathrm{Cd}$ over a range of $0.05-0.1 \mathrm{mM}$. This increase in the activity of $\mathrm{P} 450$ and $\mathrm{P} 420$ was attributed to some unknown regulatory mechanisms that could alleviate $\mathrm{Pb}$ and Cd-induced oxidative stress (Zhang et al., 2015). Hence, more research is required to identify and elucidate such mechanisms providing resistance against metal-induced oxidative stress.

\subsection{Effect of WRF species and incubation time}

The impacts of metal on WRF growth and enzymatic activity may depend on the WRF species and incubation time. Inhibition or enhancement of WRF growth and enzyme production at different concentrations of metals are presented in Figure 4 to facilitate the discussion.

\section{[Figure 4]}


The growth of both Trametes versicolor and Funalia trogii were unaffected by $\mathrm{CdCl}_{2}$ at $0.0005-0.005$ $\mathrm{mM}$ concertation. However, the growth of Trametes versicolor was inhibited at $\mathrm{CdCl}_{2}$ concentration of 0.05-1.1 mM, while the growth of Funalia trogii remained still unaffected (Mutlu et al., 2014). $\mathrm{Pb}\left(\mathrm{NO}_{3}\right)_{2}$ inhibited the growth of both Pleurotus ostreatus (Baldrian et al., 2005) and Phanerochaete chrysosporium (Li et al., 2015), particularly of the latter. By contrast, the exposure of Alcea biennis and Pleurotus ostreatus to $10-30 \mathrm{mM}$ of $\mathrm{PbO}$ and $1 \mathrm{mM}$ of $\mathrm{Pb}\left(\mathrm{NO}_{3}\right)_{2}$, respectively, enhanced their growth (Figure $4 \mathrm{a}$ ). Essential metals such as $\mathrm{CuSO}_{4}(1.3 \mathrm{mM}), \mathrm{MnSO}_{4}(3.1 \mathrm{mM}), \mathrm{ZnSO}_{4}(0.62 \mathrm{mM})$ and $\mathrm{CoSO}_{4}(0.46 \mathrm{mM})$ inhibited the growth of Lentinula edodes by $4.55 \%$ per day (Hatvani and Mécs, 2003). These results highlight that the tolerance to metal exposure varies among WRF species, possibly depending on the effectiveness of their defense mechanisms (Chen et al., 2015; Huang et al., 2010; Mutlu et al., 2014) as discussed in the next section.

Enzyme production in the presence of metals also depends on WRF species. However, it can be observed from Figure $4 \mathrm{~b}$ that the production of $\mathrm{LiP}$ and $\mathrm{MnP}$ is severely inhibited in the presence of metals regardless of WRF species. On the other hand, laccase production was increased even in the presence of some non-essential metals such as $\mathrm{Pb}, \mathrm{Cd}$ and $\mathrm{Hg}$. For instance, exposure to $0.0005-0.27 \mathrm{mM} \mathrm{CdCl}_{2}$ and $0.003 \mathrm{mM} \mathrm{Pb}\left(\mathrm{NO}_{3}\right)_{2}$ improved the production of laccase by Trametes versicolor and Lentinula edodes, respectively (Hatvani and Mécs, 2003; Mutlu et al., 2014). Interestingly, essential metals such as Zn, Ca, $\mathrm{Mn}, \mathrm{Ni}$ and $\mathrm{Co}$ at trace concentrations improved the production of laccase by Lentinula edodes but inhibited the production of MnP (Figure 4b). As noted earlier, no correlation between the inhibitory concentrations of metals and WRF growth/enzyme production could be developed because data on both WRF growth and enzyme production has not been reported in all studies.

Incubation time is important when investigating the acute and chronic toxic effects of metals on WRF. For instance, for $1.2 \mathrm{mM}$ of $\mathrm{Pb}\left(\mathrm{NO}_{3}\right)_{2}$, Phanerochaete chrysosporium growth was inhibited more severely during the first week (4.8\% per day) but then gradually subsided to <1\% per day (Huang et al., 2010; Li et al., 2015). In a study by Zhang et al. (2015), MnP and LiP production from Phanerochaete 
chrysosporium dropped gradually for $4 \mathrm{~h}$ at $0.05 \mathrm{mM} \mathrm{Cd}\left(\mathrm{NO}_{3}\right)_{2}$ but started to rise thereafter. It is possibly because the defense mechanism in WRF against metal toxicity may take some time to be activated (Zeng et al., 2015). Therefore, unless an acute assessment of metal-induced toxicity is required, an exposure time of more than one day should be used to assess the impact on WRF.

\subsection{WRF defense mechanisms}

WRF can either intracellularly uptake metals or can bind them to their cell surface which may result in a wide range of inhibitory effects including cell lysis (Chen et al., 2012; Zeng et al., 2012). Hence, WRF have developed certain defense mechanisms to alleviate toxic effects of metals. These defense mechanisms protect WRF usually by immobilizing metals via intracellular and extracellular compounds (Baldrian, 2003). Among these compounds, extracellular polymeric substances (EPS) are the most effective line of defense against metals in microbes including WRF. EPS can: (i) regulate immediate surrounding for their growth; (ii) preserve fungal morphology; and (iii) bind metals (Chen et al., 2015; Gadd et al., 2014; $\mathrm{Li}$ and $\mathrm{Yu}, 2014)$. The negative charge on EPS promotes the binding of metals on its surface, thereby reducing the dispersion and concentration of metals in the solution as well as their interaction with WRF. Moreover, the interaction of metals with EPS could also result in the formation of metal crystals, hence limiting the interaction of toxic metals with WRF (Jittawuttipoka et al., 2013; Pereira et al., 2011). In a recent study by Chen et al. (2015), EPS production by Phanerochaete chrysosporium increased linearly with the increase in the concentration of $\mathrm{Pb}$ and $\mathrm{Cd}$, indicating that WRF produce EPS for protection against metals.

In addition to EPS, enhanced secretion of organic acids such as oxalic acid or oxalates is another defense mechanism in fungi including WRF. These organic acids react with metals and form metalloid-organic molecules such as oxalate crystals (Chen et al., 2015; Guggiari et al., 2011). Formation of metalloidorganic molecules limits the dispersion of metals in solution, thereby reducing the availability of metals for fungal uptake. It has been confirmed in recent studies that the production of oxalates by $P$. chrysosporium increases in the presence of $\mathrm{Cd}$ and $\mathrm{Pb}$ (Chen et al., 2015; Li et al., 2015). 
Excessive production of ROS may induce a wide range of inhibitory effects inside the cell such as oxidation of intracellular lipids, denaturation of intracellular proteins and cell lysis (Figure 3). In metal free environment, enzymatic and non-enzymatic antioxidants provide defense against ROS. These antioxidants are comprised of catalase, superoxide dismutase and glutathione peroxidase (Bokara et al., 2008; Zhang et al., 2015). Interestingly, Zhang et al. (2015) observed increased production of enzymatic antioxidants from Phanerochaete chrysosporium in presence of $\mathrm{Pb}$ and $\mathrm{Cd}$, possibly to protect against excessive ROS due to metal-induced oxidative stress. However, excessive ROS generation in presence of metals may reduce their level or even inhibit the enzymatic antioxidants: ROS can replace cofactor in enzymes and can also interact with sulfhydryl functional groups of enzymatic antioxidants, resulting in their inactivation (Azevedo et al., 2007; Belinky et al., 2003). Similar mechanisms are likely to occur in other WRF species, but many of these mechanisms are yet to be confirmed in other common WRF species such as Trametes versicolor, Pleurotus ostreatus and Funalia trogii.

\section{Impacts on purified extracellular enzymes}

Impacts of dissolved organic and inorganic interfering compounds on the stability and catalytic efficiency have been studied mainly for laccase (Kim and Nicell, 2006a; Ramírez-Cavazos et al., 2014). Possible inhibition mechanisms of laccase catalysis are presented in Figure 5.

\section{[Figure 5]}

\subsection{Impacts of inorganic interfering compounds on laccase activity}

Presence of inorganic interfering compounds can inhibit enzymatic activity as well as their catalytic efficiency. Inhibition of purified laccases from different WRF species in the presence of inorganic interfering compounds is shown in Supplementary Data Table S3 to facilitate critical analysis. Based on the data presented in Supplementary Data Table S3, the estimated minimum range of concentration for inorganic interfering compounds that can inhibit laccase activity by $20\left(\mathrm{IC}_{20}\right), 50\left(\mathrm{IC}_{50}\right)$ and $100 \%\left(\mathrm{IC}_{100}\right)$ are presented in Table 2 to provide a general overview. 
[Table 2]

Impacts of different inorganic interfering compounds have been investigated over a broad range of concentration $(<0.05$ to $>100 \mathrm{mM})$. Inorganic compounds can inactivate enzyme via binding to type II and type III copper sites, thereby blocking the electron transport system in laccase (Kumar and Srikumar, 2012; Murugesan et al., 2009; Sadhasivam et al., 2008; Wang et al., 2010). The impact of an inorganic interfering compound depends on the combined impact of the constituent anion and cation. Based on a critical analysis of the data compiled in Supplementary Data Table S3, metal cations can be divided into two categories: (i) metals with low impact (e.g. Na, K, $\mathrm{Cu}, \mathrm{Zn}$, and $\mathrm{Mn}$ ); and (ii) metals with significant impact (e.g. $\mathrm{Hg}, \mathrm{Ca}, \mathrm{Fe}$ and $\mathrm{Cr})$.

\subsubsection{Metals with low impact}

Alkali metal ions namely $\mathrm{Na}$ and $\mathrm{K}$ have been predominantly reported not to induce any inhibitory effects on the activity of laccase. For instance, Kumar et al. (2012) reported a negligible impact of 2-10 mM Na or K on the enzymatic activity of laccase from Pleurotus ostreatus. Similarly, Sadhasivam et al. (2008) observed no inhibitory effects on the enzymatic activity of laccase from Trichoderma harzianum WLI over a concentration range of $1-5 \mathrm{mM}$ of these monovalent cations. However, these cations each at $1 \mathrm{mM}$ concentration were reported to reduce (10-20\%) the enzymatic activity of laccase from Pycnoporus $s p$. SYBC-L1 (Wang et al., 2010).

$\mathrm{Cu}, \mathrm{Mg}, \mathrm{Ca}, \mathrm{Mn}, \mathrm{Cd}, \mathrm{Co}$ and $\mathrm{Zn}$ at low concentrations $(\leq 1 \mathrm{mM})$ may not induce any inhibitory effects, rather these metals may enhance or stabilize enzymatic activity. For instance, laccases from Trametes versicolor CBS (Lorenzo et al., 2005), Meripilus giganteus (Schmidt et al., 2012), Pycnoporus sp. (Wang et al., 2010), Pycnoporus coccineus Thongkred 013 BCU (Thongkred et al., 2011), Marasmius quercophilus (Farnet et al., 2008) and Pleurotus ostreatus (Sun et al., 2017) was not inhibited in presence of $1 \mathrm{mM}$ of $\mathrm{Cu}, \mathrm{Mn}$ or $\mathrm{Zn}$ separately. On the other hand, an increase of $20 \%$ in the activity of laccase from Pycnoporus sp. SYBC-L1 was observed after addition of $10 \mathrm{mM} \mathrm{Na}$ (Wang et al., 2010). Moreover, Kumar and Srikumar (2012) reported around 45\% increase in the enzymatic activity of laccase from 
Cereus pterogonus with the addition of $1 \mathrm{mM} \mathrm{Cu}$ or $\mathrm{Mn}$ separately to the enzyme solution. In laccase catalyzed reactions, auto-oxidation of semi-quinone produced by laccase may result in the formation of quinone, and the superoxide anion produced in this reaction can then be reduced to hydrogen peroxide. In this process, both $\mathrm{Cu}^{+2}$ and $\mathrm{Mn}^{+2}$ can be reduced to $\mathrm{Cu}^{+}$and $\mathrm{Mn}^{+}$, leading to an apparent increase in the activity of laccase (Farnet et al., 2008; Munoz et al., 1997). Depletion or removal of type II copper from laccase following enzyme purification has been observed to reduce the enzymatic activity of laccase (Nagai et al., 2002; Sadhasivam et al., 2008). In such cases, the addition of $\mathrm{Cu}$ salt in enzyme solution fills the Type II copper sites of laccases, consequently improving their enzymatic activity (Nagai et al., 2002; Sadhasivam et al., 2008).

Despite the improvement in laccase activity in presence of $\mathrm{Cu}$ and $\mathrm{Mn}$ in the low concentration range, these metals can inhibit laccase activity by as much as $50 \%$ beyond a concentration of $20 \mathrm{mM}$ (Cabana et al., 2007; Kumar and Srikumar, 2012; Murugesan et al., 2009; Wang et al., 2010). This happens because these metal ions can block the active sites of the enzymes at high concentrations. Cd is known to induce severe growth inhibition in fungal species (Figure 4). However, it has been reported to have a low impact on the activity of purified laccases in most studies. For instance, the enzymatic activity of laccases from Pleurotus ostreatus (Kumar et al., 2012), Trametes versicolor CBS (Lorenzo et al., 2005) and Ganoderma lucidum (Murugesan et al., 2009) was only reduced by $15-20 \%$ in presence of $\mathrm{Cd}$ at a concentration of 10 $\mathrm{mM}$.

Impact of metals on laccase activity has only been investigated in the presence of individual metals with the exception of the study by Murugesan et al. (2009): in that study the combined effect of $\mathrm{Ca}, \mathrm{Cd}, \mathrm{Co}$, $\mathrm{Cu}, \mathrm{Li}, \mathrm{Mn}, \mathrm{Ni}, \mathrm{Zn}$, iodide and chloride ions each at $1 \mathrm{mM}$ concentration on the activity of laccase from Ganoderma lucidum was investigated. As expected, they found a slight decrease (13\%) in laccase activity after $60 \mathrm{~min}$ of incubation because all the tested ions have mostly been reported to show negligible or no impact on laccase activity at $1 \mathrm{mM}$ concentration (Kumar and Srikumar, 2012; Lorenzo et al., 2005; Sadhasivam et al., 2008; Wang et al., 2010). 


\subsubsection{Metals with significant impact}

Metals such as $\mathrm{Fe}, \mathrm{Hg}$ and $\mathrm{Cr}$ inhibit the activity of laccase by binding to its Type II and Type III copper sites (Kumar and Srikumar, 2012; Murugesan et al., 2009; Sadhasivam et al., 2008; Wang et al., 2010). Moreover, these metals block the internal electron transfer required to complete laccase catalyzed reactions and can inhibit laccase activity at low concentrations (Murugesan et al., 2009; Paterson et al., 2008; Sun et al., 2017). For instance, at a concentration of $1 \mathrm{mM}$, Fe has been reported to inhibit the enzymatic activity of laccases from Pycnoporus sp. SYBC-L1, Opuntia vulgaris and Cereus pterogonus by $65-98 \%$ (Kumar and Srikumar, 2012; Wang et al., 2010). Similarly, Cr at all tested concentrations (0.5-10 $\mathrm{mM})$ completely inhibited the enzymatic activity of laccase from Ganoderma lucidum (Murugesan et al., 2009). In addition to the aforementioned inhibitory mechanisms, Hg can inactivate enzymes due to their high affinity towards the thiol groups in proteins (Bhattacharya et al., 2014; Palmieri et al., 2000). $\mathrm{Hg}$ at a concentration of $1 \mathrm{mM}$ reduced the activity of laccases from Pleurotus ostreatus and Ganoderma lucidum by 70-100\% (Kumar et al., 2012; Murugesan et al., 2009). By contrast, laccase extracted from Trichoderma harzianum WL1 showed tolerance against $\mathrm{Fe}, \mathrm{Cr}$ and $\mathrm{Hg}$. Only 2, 14 and 25\% loss in the enzymatic activity of laccase from Trichoderma harzianum WL1 was observed in presence of $5 \mathrm{mM}$ of $\mathrm{Fe}, \mathrm{Cr}$ and $\mathrm{Hg}$, respectively (Sadhasivam et al., 2008).

\subsubsection{Impacts of anions}

Halide salts have been studied extensively for their inhibitory impacts on enzymatic activity. For instance, fluoride can reduce laccase activity by as much as $50 \%$ even at a concentration of $0.1 \mathrm{mM}$ (RamírezCavazos et al., 2014). By contrast, 2-5 mM chloride and 10-25 mM iodide has been reported to reduce the enzymatic activity of laccase by 10-20\% and 50\%, respectively (Ramírez-Cavazos et al., 2014; Schmidt et al., 2012; Wang et al., 2010). Chloride and bromide ions induce competitive inhibition, meaning that these anions prevent the binding of the substrate on to the active sites of enzymes. On the other hand, fluoride is a non-competitive inhibitor. Depending on the laccase source, the putative channels leading to type II and type III copper sites of laccases have different but defined cut-off diameter. Hence, the extent 
of inhibition induced by halides depends on the size of putative channels, influencing their accessibility to these copper sites (Purich, 2010; Rodgers et al., 2010; Xu, 1996).

As noted in Section 5.1.1, in combination with various anions, Na salts have been usually reported to pose low or negligible inhibition. However, the importance of anions on the overall toxicity of a salt can be exemplified by sodium azide $\left(\mathrm{NaN}_{3}\right)$ that is commonly used in many industrial and agriculture applications as a biocide and mutagen (Al-Qurainy and Khan, 2009; Arseculeratne et al., 2006; Bräse et al., 2005). Accordingly it has also been used to inactivate whole-cell WRF at sub-molar concentrations in laboratory scale experiments (Nguyen et al., 2014c; Yang et al., 2013c). Sodium azide is one of the most toxic compounds for extracellular enzymes. Even at a concentration of $\leq 0.01 \mathrm{mM}$, it can reduce laccase activity by 50-75\% (Ademakinwa and Agboola, 2016; Cabana et al., 2007; Kumar et al., 2012). Binding to type II and type III copper sites of enzymes is the main inhibition mechanism of sodium azide.

\subsection{Impacts of organic interfering compounds on laccase activity}

Organic compounds such as acids (e.g., oxalic acid and EDTA), surfactants (e.g., sodium dodecyl sulfate, SDS), and solvents (e.g., acetone, methanol and ethanol) are widely used in different industrial applications and can occur in wastewater (Kim and Nicell, 2006a; Zavarzina et al., 2004). Influence of organic interfering compounds on laccase activities from different WRF under a wide range of operating conditions is shown in Table 3. With a few exceptions (e.g., humic acid), all the organic interfering compounds, particularly EDTA and oxalic acid are potent inhibitors of laccase.

\section{[Table 3]}

In most studies (Table 3), significant inhibition of enzymatic activity i.e., in the range of 50-75\% has been reported in the presence of EDTA, oxalic acid, citric acid and phenol at the concentrations range of 0.01-1 mM. In addition to causing a competitive inhibition, these compounds can block type II and type III copper sites in laccase. Moreover, EDTA and citric acid can also act as copper ion chelators (Schmidt et 
al., 2012; Zavarzina et al., 2004). Organic compounds such as oxalic acid, citric acid and some organic solvents may affect enzymatic activity by altering the pH of media (Zhang et al., 2013).

Depending on their type, the interaction of surfactants with enzymes can vary. Surfactants can be categorized into two classes: (i) non-ionic surfactants such as triton X-100 (TX-100); and (ii) ionic surfactants such as cetyltrimethylammonium bromide (CTAB), sodium di-2-ethylhexylsulfosuccinate (AOT) and sodium dodecyl sulfate (SDS). Since laccase is negatively charged, only hydrophobic interactions between the alkyl chain of non-ionic surfactants and laccase are possible. Therefore, nonionic surfactants may not significantly damage the protein structure and, thus, may only mildly inhibit enzymatic activity (Delorme et al., 2011; Otzen, 2011). On the other hand, in addition to hydrophobic interactions, the ionic surfactants can interact with the charged amino residues of protein body of the enzyme and cause enzyme inactivation by protein unfolding (Azimi et al., 2016; Delorme et al., 2011; Otzen, 2011). For instance, TX-100, a non-ionic surfactant, slightly inhibited (2-10\%) the enzymatic activity of laccase from Trametes versicolor over a broad concentration range of 0.1-50 mM (Azimi et al., 2016). By contrast, ionic surfactants SDS and CTAB inhibited (50-70\%) the enzymatic activity of laccases from Trametes versicolor and Aureobasidium pullulans NAC8, respectively, even at a concentration of 0.05 - $1 \mathrm{mM}$ (Ademakinwa and Agboola, 2016; Azimi et al., 2016). Similarly, in a study by Schmidt et al. (2012), $1 \mathrm{mM}$ SDS completely inhibited the activity of laccase from Meripilus giganteus.

Interestingly, a few studies have reported increased laccase activity in presence of surfactants. For instance, the activity of laccase from Meripilus giganteus improved in the presence of nonionic surfactants such as tween 80 , tween 20 and TX-100, and even ionic surfactants such as CTAB over a concentration range of 0.1-10 mM (Schmidt et al., 2012). Similarly, for a concentration range of 0.5-1.0 $\mathrm{mM}$, AOT improved the activity of commercial laccase from Trametes versicolor by $120-150 \%$ (Azimi et al., 2016). Such improvement in laccase activity depending on the source of fungal laccase can be attributed to alterations in the physical and enzymatic characteristics of laccase i.e., conformational 
changes linked with enzyme-surfactant interaction. These conformational changes could: (i) convert laccase into more active form; (ii) alter the optimum temperature and $\mathrm{pH}$ of the laccase; and (iii) stabilize the native folded structure of laccase (Azimi et al., 2016; Goldfeder and Fishman, 2014; Zhang et al., 2012).

Kumar and Srikumar (2012) investigated the impact of urea on laccases from Cereus pterogonus and Opuntia vulgaris. They observed 50\% loss of enzymatic activity at an urea concentration of $8 \mathrm{mM}$. Urea inhibits enzymes by attacking their hydrophobic regions containing helix and $\beta$-pleated sheets, resulting in the denaturation of enzyme proteins (Kim and Nicell, 2006a; Kumar and Srikumar, 2012).

Organic solvents such as methanol, ethanol and acetone have been studied extensively for their impacts on enzymatic activity (Ademakinwa and Agboola, 2016; Farnet et al., 2008; Kumar et al., 2012; RamírezCavazos et al., 2014; Singhal et al., 2012). Solvents affect enzymatic activity mainly by changing the pH of the solution (Rodakiewicz-Nowak et al., 2000; Sadhasivam et al., 2008). Data compiled in Table 3 suggest that methanol, ethanol and acetone at concentrations ranging from 30-50\% (v/v) could reduce enzymatic activity by as much as $50 \%$. However, solvents can also improve the solubility of the apolar substrates (e.g. syringaldazine) used for the measurement of enzymatic activityat a concentration of $<30 \%$ $(\mathrm{v} / \mathrm{v})$, increasing the availability of that substrate for enzymatic oxidation, thus showing an apparent increase in laccase activity (Farnet et al., 2008).

Natural organic matter (NOM) are mainly comprised of humic acid which contains diverse functional groups such as carboxyl, amino and hydroxyl groups. Humic acid has been widely used in various applications as a representative model of NOM. In a study, $50 \mathrm{mg} / \mathrm{L}$ humic acid showed no impact on laccase activity (Sun et al., 2017). This was attributed to the negative charge on both laccase and humic acid, which possibly limited their interaction. However, as discussed further in Section 6, the impact of humic acid can be multidimensional.

\subsection{Factors influencing the inhibition of laccase}


Inhibition by organic and inorganic interfering compounds can be influenced by the source of laccase and incubation time. In addition, the extent of inhibition induced by each type of metal salt may be different.

\subsubsection{Effects of laccase source}

Laccases from different WRF species show resistance to certain toxic organic and inorganic interfering compounds such as EDTA and sodium azide (Ademakinwa and Agboola, 2016; Sadhasivam et al., 2008). To show the tolerance of laccases extracted from different WRF species, their inhibition by EDTA and sodium azide is presented in Figure 6. Inhibition data is presented in \% per min to normalize the effect of incubation time.

\section{[Figure 6]}

The impact of EDTA on laccases from 8 different sources at EDTA concentrations ranging from 0.01-100 $\mathrm{mM}$ has been investigated in different studies as shown in Figure 6. In presence of $0.1 \mathrm{mM}$ EDTA, the laccase from Meripilus giganteus (Schmidt et al., 2012) was not affected, whereas the laccase from Opuntia vulgaris (Kumar and Srikumar, 2012) and Aureobasidium pullulans NAC8 (Ademakinwa and Agboola, 2016) were inhibited by $2-2.5 \%$ per min. Activity of laccases from Opuntia vulgaris (Kumar and Srikumar, 2012), Aureobasidium pullulans NAC8 (Ademakinwa and Agboola, 2016) and Cereus pterogonus (Kumar and Srikumar, 2012) was significantly inhibited (3-3.5 \% per min) by 1 mM EDTA. On the other hand, activity of laccase from Pycnoporus sp. SYBC-L1 (Wang et al., 2010) was slightly improved at that concentration (i.e., $1 \mathrm{mM}$ ). It is interesting to note that inhibition of laccase activity did not increase linearly with EDTA concentration. For instance, EDTA at concentrations of 0.05, 0.5 and 2.5 mM inhibited the enzymatic activity of laccase from Aureobasidium pullulans NAC8 by 1.13, 1.93, and $1.87 \%$ per min, respectively (Ademakinwa and Agboola, 2016). Based on Figure 6a, laccases from Pycnoporus sp. SYBC-L1, Meripilus giganteus and Pleurotus ostreatus showed better tolerance to EDTA compared to laccases from other WRF species. 
Figure 6 reveals that sodium azide is a potent inorganic inhibitor of laccase. All laccases were significantly inhibited in the presence of sodium azide (Figure 6b). For instance, laccases from Opuntia vulgaris (Kumar and Srikumar, 2012), Aureobasidium pullulans NAC8 (Ademakinwa and Agboola, 2016) and Cereus pterogonus (Kumar and Srikumar, 2012) were inhibited by $1.5-3 \%$ per min at sodium azide concentrations of $0.005-0.5 \mathrm{mM}$. This can be attributed to the strong bonding of azide onto the T2/T3 copper of laccase, which disrupt the internal electron transfer for the enzyme. However, the laccase from Trichoderma harzianum WL1 appears to be comparatively more tolerant compared to laccases from other WRF species (Figure 6b).

\subsubsection{Effect of incubation time}

Incubation time may influence the inhibition caused by organic and inorganic interfering compounds. Impact of incubation time on laccase inhibition in the presence of different individual organic and inorganic interfering compounds is presented in Figure 7, which shows three distinct trends: (i) no influence on inhibition in case of SDS and $\mathrm{FeSO}_{4}$; (ii) moderate influence in case of organic solvents and $\mathrm{HgCl}_{2}$; and (iii) significant influence in case of sodium azide, EDTA and $\mathrm{K}_{2} \mathrm{CrO}_{4}$. The extent of inhibition of laccases by sodium azide $(0.005 \mathrm{mM})$, EDTA $(1 \mathrm{mM})$ and $\mathrm{K}_{2} \mathrm{CrO}_{4}(1 \mathrm{mM})$ increased $(40-80 \%)$ as the incubation time was increased from 5 to $60 \mathrm{~min}$. Compared to that, the percentage of inhibition varied less for $\mathrm{HgCl}_{2}(5 \mathrm{mM})$, acetone $(1.5 \mathrm{mM})$ and ethanol $(1.9 \mathrm{mM})$ with incubation time (Figure 7$)$, indicating that these interfering compounds can rapidly inactivate laccase. The incubation time for laccase based treatment processes has mostly been in the range of 12-24 h (Ashe et al., 2016; Kang et al., 2008; Nguyen et al., 2014a; Tran et al., 2010). However, Figure 7 indicates that the incubation time could be better selected depending on the wastewater derived interfering compounds of interest.

\section{[Figure 7]}

\subsubsection{Choice of salts to study the impact of metal ions}


Studies to date have investigated the impact of metals mostly by incubating their chloride or sulphate salts with laccase preparations (Kumar and Srikumar, 2012; Ramírez-Cavazos et al., 2014; Thongkred et al., 2011; Wang et al., 2010). Notably, chloride is a competitive inhibitor of laccase (Ramírez-Cavazos et al., 2014; Schmidt et al., 2012; Wang et al., 2010), which makes it difficult to assess the inhibition caused specifically by the individual metal ions if their chloride salts are used. Reported range of laccase inhibition (\% per min) by chloride and sulphate salts of different metals are presented in Figure 8. It is noted that the sulphate salts of the selected metal ions showed no inhibitory effects on laccase activity at concentrations of $5-10 \mathrm{mM}$, whereas their chloride salts inhibited laccase activity by $0.5-5 \%$ per min (Figure 8). This comparison evidences that the selected metals (i.e., $\mathrm{Cu}, \mathrm{Mg}, \mathrm{Zn}$, and $\mathrm{Mg}$ ) themselves have minimal adverse impact on laccase activity, and the toxicity shown by their salts are due to the constituent anions. In contrast to the benign metal ions shown in Figure 8, Fe salts can significantly inhibit laccase activity regardless of the salt type (e.g., chloride vs sulphate) because $\mathrm{Fe}$ is a potent inhibitor of laccase (Kumar and Srikumar, 2012; Thongkred et al., 2011; Wang et al., 2010).

\section{[Figure 8]}

\subsubsection{Choice of substrate to monitor enzymatic activity}

Laccase activity before and after incubation with the interfering compound is measured using a substrate of laccase such as ABTS, DMP or syringaldazine (Ademakinwa and Agboola, 2016; Lorenzo et al., 2005). Impacts of incubation time on the inhibitory effects of different interfering compounds have been discussed in section 5.3.2. The choice of substrate can also influence the observed level of inhibition. Since some organic interfering compounds can act as a substrate of laccase, they can interfere with laccase activity measurement by acting as a competitive inhibitor. For instance, Lorenzo et al. (2005) measured laccase activity from Trametes versicolor CBS using two different substrates namely, DMP and syringaldazine. With the addition of DMP as substrate, they observed an inhibition of $40 \%$ in laccase activity within an incubation period of $2 \mathrm{~min}$ at an oxalic acid concentration of $8 \mathrm{mM}$. On the other hand, complete inhibition of enzymatic activity was observed when syringaldazine was used as a substrate for 
the measurement of laccase activity (Lorenzo et al., 2005). The complete loss in enzymatic activity in the presence of syringaldazine was possibly because oxalic acid is a better substrate for laccase (Farnet et al., 2008; Shleev et al., 2006). Similarly, 2 mM EDTA inhibited the enzymatic activity of laccase from Trametes versicolor CBS by 10 and 20\% using DMP and syringaldazine as substrates, whereas EDTA did not show any inhibitory effects on laccase activity in the presence of ABTS (Lorenzo et al., 2005). Since EDTA induces its inhibitory effects on enzymatic activity by reducing the availability of substrate for enzymatic oxidation and acts as a non-competitive inhibitor (Johannes and Majcherczyk, 2000; Si et al., 2013), these results indicate that EDTA can interfere with the interaction of laccase with DMP and syringaldazine but its interference is not significant in case of ABTS. Therefore, the substrate for laccase measurement should be carefully selected for the assessment of inhibition by interfering compounds.

\section{Impacts of organic and inorganic interfering compounds on $\mathrm{TrOC}$ removal}

The extent and mode of inhibition of WRF enzymes by dissolved organic and inorganic interfering compounds have been analyzed in the previous sections. This section critically examines their specific impact on TrOC degradation. To date there have been a few short term batch studies in this regard (Hou et al., 2014; Kim and Nicell, 2006a; Kim and Nicell, 2006c; Sun et al., 2017; Sun et al., 2016). Impacts (i.e., inhibition or enhancement) of organic and inorganic interfering compounds on the removal of TrOCs are presented in Figure 9 to facilitate a critical discussion.

\section{[Figure 9]}

Kim and Nicell (2006a) investigated the impact of individual metal ions and organic compounds on the degradation of bisphenol $\mathrm{A}(150 \mu \mathrm{M})$ in 1-h batch experiments at a $\mathrm{pH}$ of 5 using purified laccase from Trametes versicolor. They found that the removal of bisphenol A was reduced by $40 \%$ by different concentrations of sulfide $(4.4 \mathrm{mM})$, sulfite $(1.9 \mathrm{mM})$ and thiosulfate $(1.35 \mathrm{mM})$. In another study by Kim and Nicell (2006c), removal of triclosan was reduced by 55\% in presence of $1 \mathrm{mM}$ sulfide or sulfite. Such reduction in removal of bisphenol A and triclosan in the presence of sulfide and sulfite can be attributed 
to the competitive use of dissolved oxygen by sulfide/sulfite $v s$ laccase. These impacts of sulfide and sulfite can be neutralized by providing sufficient aeration (Kim and Nicell, 2006a). On the other hand, radicals generated due to the enzymatic oxidation of phenolic substrates such as bisphenol A could oxidize thiosulfate and the resultant transformation products could act as competitive inhibitors, consequently reducing the removal of TrOCs (Wagner and Nicell, 2002).

Some organic compounds interfere in TrOC degradation as they are also substrates of laccase, leading to the competitive occupation of the reactive sites. Examples of such interfering organics include oxalic acid, phenols, E-caprolactam, phenanthrene and citric acid (Ademakinwa and Agboola, 2016; Chang et al., 2016; Lorenzo et al., 2005; Si et al., 2013). Indeed, reduction in removals of bisphenol A (5-30\%) and diclofenac (10-30\%) by laccase from Aspergillus oryzae was observed in the presence of different organic interfering compounds, namely, $\mathcal{E}$-caprolactam, phenanthrene and oxalic acid, each at a concentration of 1 mM (Paul, 2015). On the other hand, in a study by Kim and Nicell (2006a), despite being laccase substrates, $\mathcal{E}$-caprolactam and phenol each at $1 \mathrm{mM}$ concentration did not affect bisphenol A degradation by laccase from Trametes versicolor. This was possibly because bisphenol A is a better substrate for laccase at the $\mathrm{pH}$ of the media (i.e., 5).

Bisphenol A removal was reported to reduce from 60 to $40-45 \%$ in the presence of solvents, namely, acetone, methanol and formaldehyde each at a concentration of $10 \%$ (w/w) (Kim and Nicell, 2006a). In another study by Hou et al. (2014), 10\% (w/w) methanol and acetone were reported to inhibit the removal of bisphenol A $(150 \mu \mathrm{M})$ from 68 to $30-40 \%$.

It was noted in Section 5.2 that the non-ionic surfactants may have a negligible adverse impact or even an enhancing effect on the catalytic efficiency of laccase. Their specific impact on TrOC removal has been investigated in a few studies. For example, TX-100, a nonionic surfactant, was observed to improve the removal of bisphenol A (Ji et al., 2009), phenol (Zhang et al., 2012) and indole (Azimi et al., 2016). Improved transformation of these compounds in the presence of TX-100 can be attributed to increased laccase activity as well as the improved solubility of TrOCs. Moreover, transformation products could 
block the active sites of enzymes, resulting in enzyme inactivation (Purich, 2010): TX-100 protects enzymes by limiting their interaction with transformation products (Sakurai et al., 2003). However, TrOC removal improvement in presence of TX-100 may depend on its critical micelle concentration i.e., the concentration above which surfactants form aggregates (Arca-Ramos et al., 2012; Eibes et al., 2010). Below the critical micelle concentration (e.g., $0.3 \mathrm{mM})$, TX-100 exists as a monomer and may not improve the solubility of TrOCs. While at near or above the critical micelle concentration, TX-100 forms aggregates that incorporate TrOCs into its micelles to enhance their solubility, thereby improving their bioavailability for degradation by laccase (Edwards et al., 1991; Kim et al., 2007).

Among the tested metal ions including $\mathrm{Cu}, \mathrm{Co}, \mathrm{Mn}, \mathrm{Zn}$ and $\mathrm{Fe}$, each at $1 \mathrm{mM}$, only Fe inhibited the removal of bisphenol A by 10-15\% (Kim and Nicell, 2006a). Bisphenol A removal reduction by Fe is expected because it can inhibit laccase activity significantly (Section 5.1.2). Despite the significant inhibitory effects of Fe on laccase activity (Kumar et al., 2012; Thongkred et al., 2011), only 10-15\% reduction in bisphenol A removal was possibly because Fe can also oxidize phenolic substrates in absence of laccase (Lu et al., 2017).

At a concentration of $25 \mathrm{mM}$, fluoride and chloride reduced the degradation of bisphenol A by 50 and $15 \%$, respectively, while bromide ion did not inhibit bisphenol A removal. Removal of bisphenol A and triclosan in the presence of cyanide $(1 \mathrm{mM})$ was reduced by 40 and 55\%, respectively (Kim and Nicell, 2006a; Kim and Nicell, 2006c). Cyanide mainly inhibits laccase activity by dissociating copper ions from the active sites of the enzyme. Loss in enzymatic activity then results in its reduced catalytic potential (Ragusa et al., 2002).

Humic acid is found ubiquitously in surface water bodies at concentrations varying from a few tens of $\mu \mathrm{g} / \mathrm{L}$ to a few tens of $\mathrm{mg} / \mathrm{L}$ (Brum and Oliveira, 2007; Tang et al., 2014). As noted in Section 5.2, available studies report no impact of humic acid on laccase activity (Sun et al., 2017). However, Sun et al., (2016, 2017) investigated laccase (P. ostreatus) catalyzed biotransformation of $17 \beta$-estradiol $(3.7 \mu \mathrm{M})$ and triclosan $(10 \mu \mathrm{M})$ in presence of humic acid at the operating pH of 5.8-6 (Sun et al., 2017; Sun et al., 
2016). A direct relation between the concentration of humic acid and reduction in substrate removal efficiency was observed, meaning that removal of both $17 \beta$-estradiol and triclosan reduced with the increase in the concentration of humic acid. The removal of $17 \beta$-estradiol and triclosan reduced by 30 and 95\%, respectively, in presence of $50 \mathrm{mg} / \mathrm{L}$ of humic acid (Sun et al., 2017; Sun et al., 2016). Since humic acid can bind TrOCs covalently and/or non-covalently, the increase in the concentration of HA results in more TrOC binding, thereby reducing their availability for enzymatic degradation (Behera et al., 2010; Gulkowska et al., 2013; Sun et al., 2017). Humic acid can also cause dissociation of copper sites in laccase, thereby causing enzyme inhibition (Hou et al., 2014; Keum and Li, 2004). By contrast, it was reported that humic acid may facilitate electron transfer between TrOC and enzyme (Sun et al., 2013). Indeed little adverse impact or slightly enhanced TrOC removal in presence of humic acid has been observed in a few studies. For example, less than 5\% reduction in laccase catalyzed removal of bisphenol A was observed by Dillon (2014) in the presence of humic acid over a range of $10-40 \mathrm{mg} / \mathrm{L}$. Hou et al. (2014) achieved 15-20\% improvement in the degradation of bisphenol $\mathrm{A}(150 \mu \mathrm{M})$ at $\mathrm{pH}=5$ using commercial laccase from $T$. versicolor in the presence of humic acid $(10-40 \mathrm{mg} / \mathrm{L})$ following $5 \mathrm{~h}$ treatment in a continuous flow reactor equipped with an ultrafiltration membrane $(0.1 \mu \mathrm{m})$. However, it is not clear if this improvement was due to the retention of some TrOC on the humic acid -cakelayer over the membrane or enhancement of enzymatic degradation in presence of humic acid. More research is required to elucidate the factors controlling different reported roles of humic acid in enzyme based treatment systems.

Municipal and industrial wastewaters are complex and contain different combinations of organic and inorganic interfering compounds. Lu et al. (2017) investigated the transformation of triclosan in the presence of both humic acid and metal ions by using purified laccase from Trametes versicolor. They found that two monovalent cations $(\mathrm{Na}$ and $\mathrm{K})$ and humic acid $(2 \mathrm{mg} / \mathrm{L})$ did not show any effect on triclosan removal. However, a decline in triclosan removal was observed with the addition of $\mathrm{Mg}$ and $\mathrm{Ca}$ with humic acid ( $2 \mathrm{mg} / \mathrm{L})$. In a mixture of $1.25 \mathrm{mM} \mathrm{Mg} / \mathrm{Ca}$ and $2 \mathrm{mg} / \mathrm{L}$ humic acid, removal of triclosan 
was reduced by $25 \%$ (Lu et al., 2017) Interaction of divalent cations with humic acid in the reaction may result in partial neutralization of humic acid. This could instigate the binding of humic acid onto enzyme active sites, thereby reducing the catalytic efficiency of enzymes (Lu et al., 2017). Moreover, as noted earlier, binding of $\mathrm{TrOCs}$ on to humic acid can further reduce the bioavailability of compounds for laccase, thereby reducing their catalytic conversion (Behera et al., 2010; Gulkowska et al., 2013; Sun et al., 2017).

\section{Treatment of real wastewater}

Compared to the number of studies investigating the impact of selected dissolved wastewater constituents, only a few attempts to assess the enzymatic treatment of TrOCs from real municipal wastewater can be found (Auriol et al., 2008; Cruz-Morató et al., 2013; Cruz-Morató et al., 2014; Spina et al., 2015). For instance, Garcia-Morales et al. (2015) investigated the removal of nonylphenol, bisphenol A, triclosan and $17 \alpha$-ethinylestradiol from spiked groundwater samples using a crude laccases from Pycnoporus sanguineus CS43. They achieved 80-95\% removal of nonylphenol, bisphenol A and 17 $\alpha$-ethinylestradiol following a $12 \mathrm{~h}$ treatment. However, consistent with its persistence reported in other studies (Yang et al., 2013b), triclosan was removed with an efficiency of 55\%. Spina et al. (2015) observed 70-99\% removal of ketoprofen, naproxen, salicylic acid, estrone, bisphenol A and 2-hydroxybiphenyl from municipal wastewater by crude laccase from Trametes. pubescens MUT 2400 within 24 h. Similarly, Tran et al. (2013) reported 55\% removal of a recalcitrant insect repellent compound, N,N-diethyl-meta-toluamide, from municipal wastewater with purified laccase from Trametes versicolor. Notably, only a few of the aforementioned studies focusing on the removal of TrOCs from real wastewater have reported detailed wastewater characteristics (Supplementary Data Table S2). Furthermore, because the aforementioned studies did not compare the performance with suitable 'control', the specific impact of the wastewater constituents on removal performance could not be clarified. This prevents a uniform comparison of the results reported. However, Auriol et al. (2007) reported that removal of steroid hormones in municipal wastewater was reduced by $30-45 \%$ compared to their removal form solution in ultrapure water. 
The removal of resistant TrOCs can be improved with the addition of redox-mediators. The highly reactive radicals generated in laccase-mediator systems, however, can cause rapid drop in enzymatic activity (Ashe et al., 2016; Tran et al., 2013). Similar to that in studies employing synthetic wastewater (Ashe et al., 2016; Nguyen et al., 2014a), this impact was also shown in case of municipal wastewater by Garcia et al. (2011). They achieved complete removal of oxybenzone from municipal wastewater within 6 $\mathrm{h}$ by a laccase (Trametes versicolor) - mediator (ABTS) system, but $64 \%$ of the initial enzymatic activity was lost at the end of the experiment i.e., $48 \mathrm{~h}$. Notably, the extent of laccase inactivation observed in laccase-mediator system treating oxybenzone in municipal wastewater was similar to that obtained while treating oxybenzone in ultrapure water (Garcia et al., 2011), indicating that laccase inhibition caused by free redicals generated due to the oxidation of mediators is more significant than the wastewater derived interfering compounds.

Wastewater derived organic and inorganic constituents often affect the stability and catalytic efficiency of enzymes by changing the $\mathrm{pH}$ and/or temperature of wastewater (Azimi et al., 2016; Zhang et al., 2013). Temperature and $\mathrm{pH}$ can significantly affect the rate of substrate conversion and stability of enzymes (Kim and Nicell, 2006a; Nguyen et al., 2014b). Therefore, it is relevant to discuss the impacts of these factors. Temperature and $\mathrm{pH}$ for the optimum enzymatic activity depend on the source of their extraction. For instance, laccases extracted from Pleurotus ostreatus (Palmieri et al., 2003), Trametes versicolor (Han et al., 2005a), and Albatrella dispansus (Wang and Ng, 2004) have been reported to show maximum laccase activity at a temperature of 35,50 and $70{ }^{\circ} \mathrm{C}$, respectively. However, in general, the optimum temperature for most fungal laccases and peroxidases ranges from $25-30^{\circ} \mathrm{C}$ and $35-40^{\circ} \mathrm{C}$, respectively (Bosco et al., 2002; Wen et al., 2010; Zhang et al., 2008).

Depending on the source fungus, the optimum $\mathrm{pH}$ for high and stable laccase activity ranges from $3.5-$ 6.0 (Dwivedi et al., 2011). For example, the optimum pH for activity of laccase from Trametes versicolor (Han et al., 2005b; Lorenzo et al., 2005), Physisporinus rivulosus (Hildén et al., 2007) and Agaricus blazei (Ullrich et al., 2005) was 3.0-4.5, 4.0 and 5.5, respectively. Best removal of TrOCs 
ubiquitously detected in wastewater such as triclosan, diclofenac, ketoprofen and bisphenol A was achieved at pH range of 4.0-6.0 (Arboleda et al., 2012; Kim and Nicell, 2006c; Marco-Urrea et al., 2010; Margot et al., 2013; Nguyen et al., 2014b; Wang et al., 2012). The optimum pH varies for different types of TrOCs due to the difference between the redox-potential of the TrOC and enzymes (Değerli and Akpinar, 2001; Sondhi et al., 2014). In general, removal of TrOCs at varying pH results in a bell-shaped curve because TrOC removal reduces with the increase in the $\mathrm{pH}$ of the reaction mixture (Margot et al., 2013; Nguyen et al., 2014b). Reduction in the removal of TrOCs with the increase in pH can be attributed to: (i) the change in the redox-potential of enzymatic reactions; and (ii) the binding of hydroxide ions to Type II and Type III copper sites of laccase at alkaline $\mathrm{pH}$, thereby blocking the internal electron transfer (Ruijssenaars and Hartmans, 2004; Xu, 1997).

Real wastewater does not only include interfering dissolved inorganics and organics, it can also hamper fungal performance due to other microbial contaminants. The aforementioned studies reporting on the performance of enzymatic TrOC degradation from real wastewater were short-term and, hence, did not focus on the detrimental impacts of bacterial contamination on the performance of whole-cell fungi or their enzymes. However, several studies have cast light on this aspect by operating bioreactors under nonsterile environment using either synthetic (Nguyen et al., 2013; Yang et al., 2013a) or real wastewater (Badia-Fabregat et al., 2017; Cruz-Morató et al., 2013; Cruz-Morató et al., 2014; Ferrando-Climent et al., 2015; Jelic et al., 2012; Zhang and Geißen, 2012). For example, Yang et al. (2013a) investigated the performance of whole-cell Trametes versicolor for the removal of bisphenol A and diclofenac in a membrane bioreactor under non-sterile conditions using a malt-based synthetic wastewater. They observed that the removal of diclofenac was reduced by $40-50 \%$ under non-sterile conditions compared to its $99 \%$ removal achieved in sterile batch experiments. In that study, bacterial contamination was evident from microbial analysis. A few recent studies have investigated the removal of pharmaceuticals and endocrine disrupting compounds from municipal and hospital wastewater by whole-cell Phanerochaete chrysosporium or Trametes versicolor (Badia-Fabregat et al., 2017; Cruz-Morató et al., 2013; Cruz- 
Morató et al., 2014; Ferrando-Climent et al., 2015; Jelic et al., 2012; Mir-Tutusaus et al., 2016; Zhang and Geißen, 2012). In all these studies, bacterial contamination restricted long term operation of the bioreactors as the overall removal of the TrOCs gradually reduced compared to that obtained under sterile conditions. Two probable modes of bacterial interruption to fungal enzymatic expression can be perceived: i) loss of enzyme secretion capacity of fungi owing to the growth disruption under competition for substrate and bacterial colonization of the mycelia, and ii) destabilization/ consumption of secreted enzyme by bacteria (Espinosa-Ortiz et al., 2016; Libra et al., 2003; Yang et al., 2013a). Bacteria are fast growing prokaryotes compared to eukaryotic WRF and can easily outperform WRF in substrate utilization (Hai et al., 2009; Libra et al., 2003).

In addition to bacteria, other species of fungi can interrupt WRF growth and enzymatic activity. For instance, Badia-Fabregat et al. (2017) analyzed the composition of microbial communities in a fluidized bed bioreactor treating hospital wastewater. They observed other fungal species (e.g. Trichoderma asperellum and Trichoderma spp.) to overtake the originally inoculated fungi (Trametes versicolor) in the bioreactor. This is the only study demonstrating the dominance of fungal species other than the inoculated fungi in the bioreactor. Therefore, more research is needed to analyze the presence of different competing species that can suppress the growth of inoculated WRF to formulate strategies to control their proliferation in the bioreactor. A number of strategies such as immobilized fungal growth, biomass replacement and influent pretreatment as well as the use of micro-screen in the bioreactor to allow bacterial washout (while retaining WRF) have been reviewed by Asif et al. (2017) for the control of microbial contaminations. However, these strategies could only extend the operation of fungal bioreactors without bacterial contamination for a few weeks.

Based on the discussion above, it can be concluded that WRF and enzymatic processes can be an effective option for the treatment of recalcitrant industrial (e.g. pharmaceutical industries) and hospital wastewater. Municipal wastewater is rich in easily degradable organics which may interfere in the enzymatic degradation of the resistant compounds. In such cases, the enzymatic 
process could be used as a tertiary treatment for enhanced TrOC removal. Irrespective of the source of wastewater, compounds that inhibit enzymatic activity would affect the performance of enzymatic degradation. Notably, different configurations of fungal bioreactors such as fluidized bed bioreactors, membrane bioreactors and air-lift bioreactors have been studied, and their working principles, advantages and limitations have been comprehensively reviewed by Espinosa-Ortiz et al. (2016). However, the effect of interfering compounds has been studied mainly in batch studies. Therefore, this review does not cover the reactor type-specific impact.

\section{Future research}

Whole-cell WRF as well as crude/purified enzymes have demonstrated promising results for the treatment of TrOCs from synthetic wastewater. However, industrial applications of these treatment processes will require enzyme stability in presence of dissolved organic and inorganic interfering compounds. Enzymatic stability can be improved by using stabilizers. For instance, polyvinyl alcohol, polyethylene glycol (PEG), polythene and polysaccharide (e.g. Ficoll) were able to improve the stability of laccase during the treatment of bisphenol A. However, effluent toxicity was increased in the presence of PEG (Kim and Nicell, 2006b). Another option is to use encapsulation or carrier materials to improve enzymatic stability. In this regard, inert carrier materials may be preferred to avoid adsorption of denaturants.

Interestingly, the potential of crude enzymes has not been thoroughly explored for the removal of TrOCs from wastewater. Since the crude enzyme extract may contain a cocktail of enzymes and natural mediators, their use can enhance the spectrum of significantly degradable TrOCs. Moreover, it can reduce the cost of the treatment system if renewable waste products such as agricultural residues are used for fungal growth. However, the presence of unspent growth media in enzyme solution can increase organic loading in enzymatic treatment systems. A recent work demonstrates the feasibility of using functionalized $\mathrm{TiO}_{2}$ nanoparticle to directly immobilize crude enzymes. The resultant biocatalytic 
nanoparticles exhibited improved activity compared with the free crude enzyme solutions, indicating that the enzyme was selectively "purified" from the solution mixture.

Depending on the WRF species, the interfering compounds can induce a variety of inhibitory effects (Stajić et al., 2013; Zeng et al., 2015). In this regard, the interaction of organic interfering compounds such as oxalic acid, EDTA and organic solvents with WRF needs more attention as only a few studies have focused on their inhibitory effects (Bhattacharya et al., 2014). Inhibition mechanisms have been elucidated for a limited number of WRF species. Some WRF species can tolerate certain interfering compounds via their inbuilt defense mechanisms. However, factors controlling the effectiveness of defense mechanisms in WRF species remain to be elucidated.

In addition to extracellular enzymes, fungal species secrete different organic compounds (e.g. oxalates) (Chen et al., 2015; Zhang et al., 2015) that can protect them from metal-induced toxicity, their presence in the crude enzyme preparation may enhance the stability of ligninolytic enzymes. However, there is a dearth of information regarding this.

Impacts of individual interfering compounds on the removal of TrOCs by WRF-enzyme-based treatment systems has been investigated mostly for phenolic TrOCs, namely, bisphenol A, triclosan and 17ßestradiol, which are relatively well removed (>70\%) compared to the resistant non-phenolic TrOCs (Hou et al., 2014; Kim and Nicell, 2006a; Kim and Nicell, 2006c; Sun et al., 2017; Sun et al., 2016). Hence, the impacts of interfering compounds on the removal of non-phenolic TrOCs need to be investigated more systematically.

\section{Conclusion}

WRF and their ligninolytic enzymes have demonstrated their potential for efficient removal of a broad spectrum of TrOCs in lab-scale experiments under controlled environmental conditions. However, dissolved organic and inorganic interfering compounds detected in municipal and industrial wastewater can affect the growth of WRF and their enzyme production capacity. Metal ions such as $\mathrm{Cu}, \mathrm{Mn}, \mathrm{Fe}$ and 
$\mathrm{Zn}$ are essential for the growth of WRF at trace concentrations but can inhibit their growth when exposed to high concentrations. Depending on the WRF species, non-essential metals such as $\mathrm{Pb}, \mathrm{Cd}$ and $\mathrm{Hg}$ are toxic to WRF, causing protein denaturation, DNA damage, lipid oxidation and cell lysis to name a few. These mechanisms inhibit the growth of WRF as well as their enzyme production capacity. Organic interfering compounds are also toxic to WRF but they have not been studied extensively. In case of the extracellular enzymes, inorganic interfering compounds such as $\mathrm{NaCl}, \mathrm{CuSO}_{4}, \mathrm{MnSO}_{4}, \mathrm{ZnSO}_{4}$ and $\mathrm{CoSO}_{4}$ do not inhibit their enzymatic activity at a concentration of 1-5 mM. For similar concentrations, the salts of $\mathrm{Fe}, \mathrm{Hg}$ and $\mathrm{Pb}$ each are potent inhibitors of laccase, reducing the laccase activity by over $50 \%$. Among the tested inorganic interfering compounds, sodium azide is one of the most toxic compounds and can completely inactivate laccase at a very low concentration $(<0.01 \mathrm{mM})$. Inorganic interfering compounds inhibit the activity of enzymes mainly by: (i) blocking the internal electron transfer; (ii) binding to type II and type III sites of copper; and (iii) binding to the thiols groups of proteins. Organic interfering compounds such as EDTA, oxalic acid and organic solvents can also inhibit the enzymatic activity of laccase, involving inhibitory mechanisms including: (i) competitive inhibition; (ii) protein denaturation; and (iii) alteration in the $\mathrm{pH}$ of solutions. It is observed that inhibition of WRF and their ligninolytic enzymes depends on type of WRF species and experimental conditions as well as on the concentration of interfering compounds. Depending on the type and concentration, interfering compounds such as sulfites, sulfides, ammonium chloride, sodium fluoride and organic solvents can affect TrOC removal. Based on short term experiments, 50-90\% removal of TrOCs from real wastewater can be achieved in whole-cell WRF or enzyme based treatment systems.

\section{Acknowledgements}

This research has been conducted with the support of the Australian Government Research Training Program Scholarship.

\section{References}


Ademakinwa, A.N., Agboola, F.K., 2016. Biochemical characterization and kinetic studies on a purified yellow laccase from newly isolated Aureobasidium pullulans NAC8 obtained from soil containing decayed plant matter. J. Genet. Eng. Biotechnol. 14, 143-151.

Al-Qurainy, F., Khan, S., 2009. Mutagenic effects of sodium azide and its application in crop improvement. World Appl. Sci. J. 6, 1589-1601.

Arboleda, C., Cabana, H., De Pril, E., Jones, J.P., Jiménez, G., Mejía, A., Agathos, S.N., Penninckx, M., 2012. Elimination of bisphenol A and triclosan using the enzymatic system of autochthonous Colombian forest fungi. ISRN Biotechnol. 2013, (doi: 10.5402/2013/968241).

Arca-Ramos, A., Eibes, G., Moreira, M., Feijoo, G., Lema, J., 2012. Surfactant-assisted two phase partitioning bioreactors for laccase-catalyzed degradation of anthracene. Process Biochem. 47, 11151121.

Arseculeratne, S., Atapattu, D., Balasooriya, P., Fernando, R., 2006. The effects of biocides (antiseptics and disinfectants) on the endospores of Rhinosporidium seeberi. Indian J. Med. Microbiol. 24, 85.

Ashe, B., Nguyen, L.N., Hai, F.I., Lee, D.-J., van de Merwe, J.P., Leusch, F.D., Price, W.E., Nghiem, L.D., 2016. Impacts of redox-mediator type on trace organic contaminants degradation by laccase: Degradation efficiency, laccase stability and effluent toxicity. Int. Biodeterior. Biodegrad. 113, 169-176.

Asif, M.B., Hai, F.I., Singh, L., Price, W.E., Nghiem, L.D., 2017. Degradation of Pharmaceuticals and Personal Care Products by White-Rot Fungi-a Critical Review. Curr. Pollution Rep. 3,88-103.

Auriol, M., Filali-Meknassi, Y., Adams, C.D., Tyagi, R.D., Noguerol, T.-N., Pina, B., 2008. Removal of estrogenic activity of natural and synthetic hormones from a municipal wastewater: efficiency of horseradish peroxidase and laccase from Trametes versicolor. Chemosphere 70, 445-452.

Auriol, M., Filali-Meknassi, Y., Tyagi, R.D., Adams, C.D., 2007. Laccase-catalyzed conversion of natural and synthetic hormones from a municipal wastewater. Water Res. 41, 3281-3288.

Azevedo, M.-M., Carvalho, A., Pascoal, C., Rodrigues, F., Cássio, F., 2007. Responses of antioxidant defenses to $\mathrm{Cu}$ and $\mathrm{Zn}$ stress in two aquatic fungi. Sci. Total Environ. 377, 233-243.

Azimi, M., Nafissi-Varcheh, N., Mogharabi, M., Faramarzi, M.A., Aboofazeli, R., 2016. Study of laccase activity and stability in the presence of ionic and non-ionic surfactants and the bioconversion of indole in laccase-TX-100 system. J. Mol. Catal. B: Enzym. 126, 69-75.

Badia-Fabregat, M., Lucas, D., Tuomivirta, T., Fritze, H., Pennanen, T., Rodríguez-Mozaz, S., Barceló, D., Caminal, G., Vicent, T., 2017. Study of the effect of the bacterial and fungal communities present in real wastewater effluents on the performance of fungal treatments. Sci. Total Environ. 579, 366-377.

Baldrian, P., 2003. Interactions of heavy metals with white-rot fungi. Enzyme Microb. Technol. 32, 7891.

Baldrian, P., Gabriel, J., 2002. Copper and cadmium increase laccase activity in Pleurotus ostreatus. FEMS Microbiol. Lett. 206, 69-74.

Baldrian, P., Valášková, V., Merhautová, V., Gabriel, J., 2005. Degradation of lignocellulose by Pleurotus ostreatus in the presence of copper, manganese, lead and zinc. Res. Microbiol. 156, 670-676.

Bayramoğlu, G., Arıca, M.Y., 2008. Removal of heavy mercury (II), cadmium (II) and zinc (II) metal ions by live and heat inactivated Lentinus edodes pellets. Chem. Eng. J. 143, 133-140.

Behera, S.K., Oh, S.-Y., Park, H.-S., 2010. Sorption of triclosan onto activated carbon, kaolinite and montmorillonite: Effects of pH, ionic strength, and humic acid. J. Hazard. Mater. 179, 684-691.

Belinky, P.A., Flikshtein, N., Lechenko, S., Gepstein, S., Dosoretz, C.G., 2003. Reactive oxygen species and induction of lignin peroxidase in Phanerochaete chrysosporium. Appl. Environ. Microbiol. 69, 65006506 . 
Bhattacharya, S., Das, A., Prashanthi, K., Palaniswamy, M., Angayarkanni, J., 2014. Mycoremediation of Benzo [a] pyrene by Pleurotus ostreatus in the presence of heavy metals and mediators. 3 Biotech 4, 205211.

Bokara, K.K., Brown, E., McCormick, R., Yallapragada, P.R., Rajanna, S., Bettaiya, R., 2008. Leadinduced increase in antioxidant enzymes and lipid peroxidation products in developing rat brain. BioMetals 21, 9-16.

Bosco, F., Capolongo, A., Ruggeri, B., 2002. Effect of temperature, pH, ionic strength, and sodium nitrate on activity of LiPs: Implications for bioremediation. Bioremediation J. 6, 65-76.

Bräse, S., Gil, C., Knepper, K., Zimmermann, V., 2005. Organic azides: an exploding diversity of a unique class of compounds. Angew. Chem. Int. Ed. 44, 5188-5240.

Brum, M.C., Oliveira, J.F., 2007. Removal of humic acid from water by precipitate flotation using cationic surfactants. Miner. Eng. 20, 945-949.

Bugg, T.D., Ahmad, M., Hardiman, E.M., Rahmanpour, R., 2011. Pathways for degradation of lignin in bacteria and fungi. Nat. Prod. Rep. 28, 1883-1896.

Cabana, H., Alexandre, C., Agathos, S.N., Jones, J.P., 2009. Immobilization of laccase from the white rot fungus Coriolopsis polyzona and use of the immobilized biocatalyst for the continuous elimination of endocrine disrupting chemicals. Bioresour. Technol. 100, 3447-3458.

Cabana, H., Jones, J.P., Agathos, S.N., 2007. Preparation and characterization of cross-linked laccase aggregates and their application to the elimination of endocrine disrupting chemicals. J. Biotechnol. 132, 23-31.

Carletti, G., Fatone, F., Bolzonella, D., Cecchi, F., 2008. Occurrence and fate of heavy metals in large wastewater treatment plants treating municipal and industrial wastewaters. Wat. Sci. Tech. 57, 13291336.

Chang, Y.-T., Lee, J.-F., Liu, K.-H., Liao, Y.-F., Yang, V., 2016. Immobilization of fungal laccase onto a nonionic surfactant-modified clay material: application to PAH degradation. Environ. Sci. Pollut. Res. 23, 4024-4035.

Chen, A., Shang, C., Zeng, G., Chen, G., Shao, J., Zhang, J., Huang, H., 2015. Extracellular secretions of Phanerochaete chrysosporium on Cd toxicity. Int. Biodeterior. Biodegrad. 105, 73-79.

Chen, A., Zeng, G., Chen, G., Liu, L., Shang, C., Hu, X., Lu, L., Chen, M., Zhou, Y., Zhang, Q., 2014. Plasma membrane behavior, oxidative damage, and defense mechanism in Phanerochaete chrysosporium under cadmium stress. Process Biochem. 49, 589-598.

Chen, G., Fan, J., Liu, R., Zeng, G., Chen, A., Zou, Z., 2012. Removal of Cd (II), Cu (II) and Zn (II) from aqueous solutions by live Phanerochaete chrysosporium. Environ. Technol. 33, 2653-2659.

Cruz-Morató, C., Ferrando-Climent, L., Rodriguez-Mozaz, S., Barceló, D., Marco-Urrea, E., Vicent, T., Sarrà, M., 2013. Degradation of pharmaceuticals in non-sterile urban wastewater by Trametes versicolor in a fluidized bed bioreactor. Water Res. 47, 5200-5210.

Cruz-Morató, C., Lucas, D., Llorca, M., Rodriguez-Mozaz, S., Gorga, M., Petrovic, M., Barceló, D., Vicent, T., Sarrà, M., Marco-Urrea, E., 2014. Hospital wastewater treatment by fungal bioreactor: removal efficiency for pharmaceuticals and endocrine disruptor compounds. Sci. Total Environ. 493, 365376.

Dashtban, M., Schraft, H., Syed, T.A., Qin, W., 2010. Fungal biodegradation and enzymatic modification of lignin. Int. J. Biochem. Mol. Biol. 1, 36-50.

Değerli, N., Akpinar, M.A., 2001. A novel concentration method for concentrating solutions of protein extracts based on dialysis techniques. Anal. Biochem. 297, 192-194. 
Delorme, V., Dhouib, R., Canaan, S., Fotiadu, F., Carrière, F., Cavalier, J.-F., 2011. Effects of surfactants on lipase structure, activity, and inhibition. Pharm. Res. 28, 1831-1842.

Dillon, A.F., 2014. Comparison of the Enzymatic Removal of Trace Organic Contaminants under the Presence of Organic Wastewater Constituents, School of Civil, Mining and Environmental Engineering. University of Wollongong, Wollongong.

Dwivedi, U.N., Singh, P., Pandey, V.P., Kumar, A., 2011. Structure-function relationship among bacterial, fungal and plant laccases. J. Mol. Catal. B: Enzym. 68, 117-128.

Edwards, D.A., Luthy, R.G., Liu, Z., 1991. Solubilization of polycyclic aromatic hydrocarbons in micellar nonionic surfactant solutions. Environ. Sci. Technol. 25, 127-133.

Eibes, G., McCann, C., Pedezert, A., Moreira, M.T., Feijoo, G., Lema, J.M., 2010. Study of mass transfer and biocatalyst stability for the enzymatic degradation of anthracene in a two-phase partitioning bioreactor. Biochem. Eng. J. 51, 79-85.

Errasquin, E.L., Vazquez, C., 2003. Tolerance and uptake of heavy metals by Trichoderma atroviride isolated from sludge. Chemosphere 50, 137-143.

Espinosa-Ortiz, E.J., Rene, E.R., Pakshirajan, K., van Hullebusch, E.D., Lens, P.N., 2016. Fungal pelleted reactors in wastewater treatment: applications and perspectives. Chem. Eng. J. 283, 553-571.

Fabbrini, M., Galli, C., Gentili, P., 2002. Comparing the catalytic efficiency of some mediators of laccase. J. Mol. Catal. B: Enzym. 16, 231-240.

Farnet, A., Gil, G., Ferre, E., 2008. Effects of pollutants on laccase activities of Marasmius quercophilus, a white-rot fungus isolated from a Mediterranean schlerophyllous litter. Chemosphere 70, 895-900.

Ferrando-Climent, L., Cruz-Morató, C., Marco-Urrea, E., Vicent, T., Sarrà, M., Rodriguez-Mozaz, S., Barceló, D., 2015. Non conventional biological treatment based on Trametes versicolor for the elimination of recalcitrant anticancer drugs in hospital wastewater. Chemosphere 136, 9-19.

Gadd, G.M., Bahri-Esfahani, J., Li, Q., Rhee, Y.J., Wei, Z., Fomina, M., Liang, X., 2014. Oxalate production by fungi: significance in geomycology, biodeterioration and bioremediation. Fungal Biol. Rev. $28,36-55$.

Gao, D., Du, L., Yang, J., Wu, W.-M., Liang, H., 2010. A critical review of the application of white rot fungus to environmental pollution control. Crit. Rev. Biotechnol. 30, 70-77.

Garcia-Morales, R., Rodríguez-Delgado, M., Gomez-Mariscal, K., Orona-Navar, C., Hernandez-Luna, C., Torres, E., Parra, R., Cárdenas-Chávez, D., Mahlknecht, J., Ornelas-Soto, N., 2015. Biotransformation of endocrine-disrupting compounds in groundwater: bisphenol A, nonylphenol, ethynylestradiol and triclosan by a laccase cocktail from pycnoporus sanguineus CS43. Water, Air, Soil Pollut. 226, 1-14.

Garcia, H.A., Hoffman, C.M., Kinney, K.A., Lawler, D.F., 2011. Laccase-catalyzed oxidation of oxybenzone in municipal wastewater primary effluent. Water Res. 45, 1921-1932.

Gavrilescu, M., Demnerová, K., Aamand, J., Agathos, S., Fava, F., 2015. Emerging pollutants in the environment: present and future challenges in biomonitoring, ecological risks and bioremediation. $\mathrm{N}$. Biotechnol. 32, 147-156.

Golan-Rozen, N., Chefetz, B., Ben-Ari, J., Geva, J., Hadar, Y., 2011. Transformation of the recalcitrant pharmaceutical compound carbamazepine by Pleurotus ostreatus: role of cytochrome P450 monooxygenase and manganese peroxidase. Environ. Sci. Technol. 45, 6800-6805.

Goldfeder, M., Fishman, A., 2014. Modulating enzyme activity using ionic liquids or surfactants. Appl. Microbiol. Biotechnol. 98, 545-554.

Grąz, M., Pawlikowska-Pawlęga, B., Jarosz-Wilkołazka, A., 2011. Growth inhibition and intracellular distribution of $\mathrm{Pb}$ ions by the white-rot fungus Abortiporus biennis. Int. Biodeterior. Biodegrad. 65, 124129. 
Grodowska, K., Parczewski, A., 2010. Organic solvents in the pharmaceutical industry. Acta Pol. Pharm. 67, 3-12.

Guggiari, M., Bloque, R., Aragno, M., Verrecchia, E., Job, D., Junier, P., 2011. Experimental calciumoxalate crystal production and dissolution by selected wood-rot fungi. Int. Biodeterior. Biodegrad. 65 , 803-809.

Gulkowska, A., Sander, M., Hollender, J., Krauss, M., 2013. Covalent binding of sulfamethazine to natural and synthetic humic acids: assessing laccase catalysis and covalent bond stability. Environ. Sci. Technol. 47, 6916-6924.

Gupta, A., Joia, J., Sood, A., Sood, R., Kaur, G., 2016. Microbes as Potential Tool for Remediation of Heavy Metals: A Review. J. Microb. Biochem. Technol., 364-372.

Hai, F.I., Yamamoto, K., Fukushi, K., 2007. Hybrid treatment systems for dye wastewater. Crit. Rev. Environ. Sci. Technol. 37, 315-377.

Hai, F.I., Yamamoto, K., Nakajima, F., Fukushi, K., 2009. Factors governing performance of continuous fungal reactor during non-sterile operation-the case of a membrane bioreactor treating textile wastewater. Chemosphere 74, 810-817.

Hall, J., 2002. Cellular mechanisms for heavy metal detoxification and tolerance. J. Exp. Bot. 53, 1-11. Haltiwanger, R.S., Lowe, J.B., 2004. Role of glycosylation in development. Annu. Rev. Biochem. 73, 491-537.

Hamilton, S.R., Gerngross, T.U., 2007. Glycosylation engineering in yeast: the advent of fully humanized yeast. Curr. Opin. Biotechnol. 18, 387-392.

Han, M., Choi, H., Song, H., 2005. Purification and characterization of laccase from the white rot fungus Trametes versicolor. J. Microbiol. - Seoul 43, 555.

Hatvani, N., Mécs, I., 2003. Effects of certain heavy metals on the growth, dye decolorization, and enzyme activity of Lentinula edodes. Ecotoxicol. Environ. Saf. 55, 199-203.

Hildén, K., Hakala, T.K., Maijala, P., Lundell, T.K., Hatakka, A., 2007. Novel thermotolerant laccases produced by the white-rot fungus Physisporinus rivulosus. Appl. Microbiol. Biotechnol. 77, 301-309.

Hou, J., Dong, G., Luu, B., Sengpiel, R.G., Ye, Y., Wessling, M., Chen, V., 2014. Hybrid membrane with TiO 2 based bio-catalytic nanoparticle suspension system for the degradation of bisphenol-A. Bioresour. Technol. 169, 475-483.

Huang, D.-L., Zeng, G.-M., Feng, C.-L., Hu, S., Zhao, M.-H., Lai, C., Zhang, Y., Jiang, X.-Y., Liu, H.-L., 2010. Mycelial growth and solid-state fermentation of lignocellulosic waste by white-rot fungus Phanerochaete chrysosporium under lead stress. Chemosphere 81, 1091-1097.

Jelic, A., Cruz-Morató, C., Marco-Urrea, E., Sarrà, M., Perez, S., Vicent, T., Petrović, M., Barcelo, D., 2012. Degradation of carbamazepine by Trametes versicolor in an air pulsed fluidized bed bioreactor and identification of intermediates. Water Res. 46, 955-964.

Ji, G., Zhang, H., Huang, F., Huang, X., 2009. Effects of nonionic surfactant Triton X-100 on the laccasecatalyzed conversion of bisphenol A. J. Environ. Sci. (China) 21, 1486-1490.

Jittawuttipoka, T., Planchon, M., Spalla, O., Benzerara, K., Guyot, F., Cassier-Chauvat, C., Chauvat, F., 2013. Multidisciplinary evidences that Synechocystis PCC6803 exopolysaccharides operate in cell sedimentation and protection against salt and metal stresses. PloS one 8, e55564.

Johannes, C., Majcherczyk, A., 2000. Laccase activity tests and laccase inhibitors. J. Biotechnol. 78, 193199.

Jung, S.T., Kang, T.H., Kelton, W., Georgiou, G., 2011. Bypassing glycosylation: engineering aglycosylated full-length IgG antibodies for human therapy. Curr. Opin. Biotechnol. 22, 858-867. 
Kang, A.-R., Choi, H.-T., Song, H.-G., 2008. Optimization of bisphenol A biodegradation by Trametes versicolor. Korean. J. Microbiol. 44, 37-42.

Keum, Y.-S., Li, Q., 2004. Copper dissociation as a mechanism of fungal laccase denaturation by humic acid. Appl. Microbiol. Biotechnol. 64, 588-592.

Khammuang, S., Yuwa-amornpitak, T., Svasti, J., Sarnthima, R., 2013. Copper induction of laccases by Lentinus polychrous under liquid-state fermentation. Biocatal. Agric. Biotechnol. 2, 357-362.

Kim, E., Chae, H., Chu, K., 2007. Enzymatic oxidation of aqueous pentachlorophenol. J. Environ. Sci. 19, 1032-1036.

Kim, J.-S., Ahn, T., Yim, S.-K., Yun, C.-H., 2002. Differential effect of copper (II) on the cytochrome P450 enzymes and NADPH-cytochrome P450 reductase: inhibition of cytochrome P450-catalyzed reactions by copper (II) ion. Biochemistry 41, 9438-9447.

Kim, S.H., Jung, K.H., Hwang, H.C., Chai, Y.G., 2013. Proteomic analysis of the oxidative stress response induced by low-dose hydrogen peroxide in Bacillus anthracis. J. Microbiol. Biotechnol. 23, 750758.

Kim, Y.-J., Nicell, J.A., 2006a. Impact of reaction conditions on the laccase-catalyzed conversion of bisphenol A. Bioresour. Technol. 97, 1431-1442.

Kim, Y.-J., Nicell, J.A., 2006b. Laccase-catalyzed oxidation of bisphenol A with the aid of additives. Process Biochem. 41, 1029-1037.

Kim, Y.J., Nicell, J.A., 2006c. Laccase-catalysed oxidation of aqueous triclosan. J. Chem. Technol. Biotechnol. 81, 1344-1352.

Kiyono, M., Miyahara, K., Sone, Y., Pan-Hou, H., Uraguchi, S., Nakamura, R., Sakabe, K., 2010. Engineering expression of the heavy metal transporter MerC in Saccharomyces cerevisiae for increased cadmium accumulation. Appl. Microbiol. Biotechnol. 86, 753-759.

Kües, U., 2015. Fungal enzymes for environmental management. Curr. Opin. Biotechnol. 33, 268-278.

Kumar, G.N., Srikumar, K., 2012. Characterization of xerophytic thermophilic laccase exhibiting metal ion-dependent dye decolorization potential. Appl. Biochem. Biotechnol. 167, 662-676.

Kumar, V.V., Sathyaselvabala, V., Premkumar, M., Vidyadevi, T., Sivanesan, S., 2012. Biochemical characterization of three phase partitioned laccase and its application in decolorization and degradation of synthetic dyes. J. Mol. Catal. B: Enzym. 74, 63-72.

Li, N., Zeng, G., Huang, D., Huang, C., Lai, C., Wei, Z., Xu, P., Zhang, C., Cheng, M., Yan, M., 2015. Response of extracellular carboxylic and thiol ligands (oxalate, thiol compounds) to $\mathrm{Pb} 2+$ stress in Phanerochaete chrysosporium. Environ. Sci. Pollut. Res. 22, 12655-12663.

Li, W.-W., Yu, H.-Q., 2014. Insight into the roles of microbial extracellular polymer substances in metal biosorption. Bioresour. Technol. 160, 15-23.

Libra, J.A., Borchert, M., Banit, S., 2003. Competition strategies for the decolorization of a textilereactive dye with the white-rot fungi Trametes versicolor under non-sterile conditions. Biotechnol. Bioeng. 82, 736-744.

Lloret, L., Eibes, G., Feijoo, G., Moreira, M.T., Lema, J.M., 2012. Degradation of estrogens by laccase from Myceliophthora thermophila in fed-batch and enzymatic membrane reactors. J. Hazard. Mater. 213214, 175-183.

Lorenzo, M., Moldes, D., Couto, S.R.g., Sanromán, M., 2005. Inhibition of laccase activity from Trametes versicolor by heavy metals and organic compounds. Chemosphere 60, 1124-1128.

Lu, J., Shi, Y., Ji, Y., Kong, D., Huang, Q., 2017. Transformation of triclosan by laccase catalyzed oxidation: The influence of humic acid-metal binding process. Environ. Pollut. 220, 1418-1423. 
Luo, Y., Guo, W., Ngo, H.H., Nghiem, L.D., Hai, F.I., Zhang, J., Liang, S., Wang, X.C., 2014. A review on the occurrence of micropollutants in the aquatic environment and their fate and removal during wastewater treatment. Sci. Total Environ. 473, 619-641.

Maestre-Reyna, M., Liu, W.-C., Jeng, W.-Y., Lee, C.-C., Hsu, C.-A., Wen, T.-N., Wang, A.H.-J., Shyur, L.-F., 2015. Structural and functional roles of glycosylation in fungal laccase from Lentinus sp. PloS one $10, \mathrm{e} 0120601$.

Magner, E., 2013. Immobilisation of enzymes on mesoporous silicate materials. Chem. Soc. Rev. 42, 6213-6222.

Marco-Urrea, E., Pérez-Trujillo, M., Cruz-Morató, C., Caminal, G., Vicent, T., 2010. White-rot fungusmediated degradation of the analgesic ketoprofen and identification of intermediates by HPLC-DAD-MS and NMR. Chemosphere 78, 474-481.

Marco-Urrea, E., Pérez-Trujillo, M., Vicent, T., Caminal, G., 2009. Ability of white-rot fungi to remove selected pharmaceuticals and identification of degradation products of ibuprofen by Trametes versicolor. Chemosphere 74, 765-772.

Margot, J., Copin, P.-J., von Gunten, U., Barry, D.A., Holliger, C., 2015. Sulfamethoxazole and isoproturon degradation and detoxification by a laccase-mediator system: Influence of treatment conditions and mechanistic aspects. Biochem. Eng. J. 103, 47-59.

Margot, J., Maillard, J., Rossi, L., Barry, D.A., Holliger, C., 2013. Influence of treatment conditions on the oxidation of micropollutants by Trametes versicolor laccase. New Biotechnol. 30, 803-813.

Matityahu, A., Hadar, Y., Belinky, P.A., 2010. Involvement of protein kinase C in lignin peroxidase expression in oxygenated cultures of the white rot fungus Phanerochaete chrysosporium. Enzyme Microb. Technol. 47, 59-63.

Mir-Tutusaus, J.A., Sarrà, M., Caminal, G., 2016. Continuous treatment of non-sterile hospital wastewater by Trametes versicolor: How to increase fungal viability by means of operational strategies and pretreatments. J. Hazard. Mater. 318, 561-570.

Munoz, C., Guillén, F., Martínez, A., Martínez, M., 1997. Laccase isoenzymes of Pleurotus eryngii: characterization, catalytic properties, and participation in activation of molecular oxygen and $\mathrm{Mn} 2+$ oxidation. Appl. Environ. Microbiol. 63, 2166-2174.

Murugesan, K., Kim, Y.-M., Jeon, J.-R., Chang, Y.-S., 2009. Effect of metal ions on reactive dye decolorization by laccase from Ganoderma lucidum. J. Hazard. Mater. 168, 523-529.

Mutlu, F., Kahraman, S., Apohan, E., 2014. Polyamine and Laccase Production under Cadmium Stress in Trametes (Coriolus) versicolor and Funalia trogii. Ekoloji 23, 29-35.

Nagai, K., Ihara, Y., Wada, Y., Taniguchi, N., 1997. N-glycosylation is requisite for the enzyme activity and Golgi retention of N-acetylglucosaminyltransferase III. Glycobiology 7, 769-776.

Nagai, M., Sato, T., Watanabe, H., Saito, K., Kawata, M., Enei, H., 2002. Purification and characterization of an extracellular laccase from the edible mushroom Lentinula edodes, and decolorization of chemically different dyes. Appl. Microbiol. Biotechnol. 60, 327-335.

Nguyen, L.N., Hai, F.I., Kang, J., Leusch, F.D., Roddick, F., Magram, S.F., Price, W.E., Nghiem, L.D., 2014a. Enhancement of trace organic contaminant degradation by crude enzyme extract from Trametes versicolor culture: Effect of mediator type and concentration. J. Taiwan Inst. Chem. Eng. 45, 1855-1862.

Nguyen, L.N., Hai, F.I., Price, W.E., Kang, J., Leusch, F.D., Roddick, F., van de Merwe, J.P., Magram, S.F., Nghiem, L.D., 2015. Degradation of a broad spectrum of trace organic contaminants by an enzymatic membrane reactor: complementary role of membrane retention and enzymatic degradation. Int. Biodeterior. Biodegrad. 99, 115-122. 
Nguyen, L.N., Hai, F.I., Price, W.E., Leusch, F.D., Roddick, F., McAdam, E.J., Magram, S.F., Nghiem, L.D., 2014b. Continuous biotransformation of bisphenol A and diclofenac by laccase in an enzymatic membrane reactor. Int. Biodeterior. Biodegrad. 95, 25-32.

Nguyen, L.N., Hai, F.I., Yang, S., Kang, J., Leusch, F.D., Roddick, F., Price, W.E., Nghiem, L.D., 2013. Removal of trace organic contaminants by an MBR comprising a mixed culture of bacteria and white-rot fungi. Bioresour. Technol. 148, 234-241.

Nguyen, L.N., Hai, F.I., Yang, S., Kang, J., Leusch, F.D.L., Roddick, F., Price, W.E., Nghiem, L.D., 2014c. Removal of pharmaceuticals, steroid hormones, phytoestrogens, UV-filters, industrial chemicals and pesticides by Trametes versicolor: Role of biosorption and biodegradation. Int. Biodeterior. Biodegrad. 88, 169-175.

OECD, 2001. SIDS Initial Assessment Report. OECD

(http://www.inchem.org/documents/sids/sids/77929.pdf), Switzerland.

Otzen, D., 2011. Protein-surfactant interactions: a tale of many states. Biochim. Biophys. Acta.-Proteins and Proteom. 1814, 562-591.

Palmieri, G., Cennamo, G., Faraco, V., Amoresano, A., Sannia, G., Giardina, P., 2003. Atypical laccase isoenzymes from copper supplemented Pleurotus ostreatus cultures. Enzyme Microb. Technol. 33, 220230.

Palmieri, G., Giardina, P., Bianco, C., Fontanella, B., Sannia, G., 2000. Copper induction of laccase isoenzymes in the ligninolytic fungus Pleurotus ostreatus. Appl. Environ. Microbiol. 66, 920-924.

Paterson, R.R., Meon, S., Abidin, M.Z., Lima, N., 2008. Prospects for inhibition of lignin degrading enzymes to control Ganoderma white rot of oil palm. Curr. Enzyme Inhib. 4, 172-179.

Paul, A., 2015. A comparative study of bacterial and fungal laccase: potential for Trace Organic Contaminant degradation, School of Civil, Mining and Environmetal Engineering. University of Wollongong, Wollongong.

Peña-Castro, J.M., Martínez-Jerónimo, F., Esparza-García, F., Cañizares-Villanueva, R.O., 2004.

Phenotypic plasticity in Scenedesmus incrassatulus (Chlorophyceae) in response to heavy metals stress. Chemosphere 57, 1629-1636.

Pereira, S., Micheletti, E., Zille, A., Santos, A., Moradas-Ferreira, P., Tamagnini, P., De Philippis, R., 2011. Using extracellular polymeric substances (EPS)-producing cyanobacteria for the bioremediation of heavy metals: do cations compete for the EPS functional groups and also accumulate inside the cell? Microbiology 157, 451-458.

Pointing, S., 2001. Feasibility of bioremediation by white-rot fungi. Appl. Microbiol. Biotechnol. 57, 2033.

Poirier, I., Jean, N., Guary, J., Bertrand, M., 2008. Responses of the marine bacterium Pseudomonas fluorescens to an excess of heavy metals: Physiological and biochemical aspects. Sci. Total Environ. 406, 76-87.

Purich, D.L., 2010. Enzyme kinetics: catalysis \& control: a reference of theory and best-practice methods. Elsevier, Netherlands.

Ragusa, S., Cambria, M.T., Pierfederici, F., Scirè, A., Bertoli, E., Tanfani, F., Cambria, A., 2002. Structure-activity relationship on fungal laccase from Rigidoporus lignosus: a Fourier-transform infrared spectroscopic study. Biochim. Biophys. Acta 1601, 155-162.

Ramírez-Cavazos, L.I., Junghanns, C., Ornelas-Soto, N., Cárdenas-Chávez, D.L., Hernández-Luna, C., Demarche, P., Enaud, E., García-Morales, R., Agathos, S.N., Parra, R., 2014. Purification and characterization of two thermostable laccases from Pycnoporus sanguineus and potential role in degradation of endocrine disrupting chemicals. J. Mol. Catal. B: Enzym. 108, 32-42. 
Reaves, E., 2004. Ethylenediaminetetraacetic acid (EDTA) and the salts of EDTA: Science Assessment Document for Tolerance Reassessment USEPA. https://www.epa.gov/sites/production/files/201504/documents/edta.pdf.

Riemenschneider, W., Tanifuji, M., 2000. Oxalic Acid, in: Elvers, B., Hawkins, S., Russey, W. (Eds.), Ullmann's Encyclopedia of Industrial Chemistry. Wiley-VCH, Weinheim. (ISBN: 9783527306732).

Riva, S., 2006. Laccases: blue enzymes for green chemistry. Trends Biotechnol. 24, 219-226.

Rodakiewicz-Nowak, J., Kasture, S., Dudek, B., Haber, J., 2000. Effect of various water-miscible solvents on enzymatic activity of fungal laccases. J. Mol. Catal. B: Enzym. 11, 1-11.

Rodarte-Morales, A., Feijoo, G., Moreira, M., Lema, J., 2011. Degradation of selected pharmaceutical and personal care products (PPCPs) by white-rot fungi. W. J. Microbio. Biotechnol. 27, 1839-1846.

Rodgers, C.J., Blanford, C.F., Giddens, S.R., Skamnioti, P., Armstrong, F.A., Gurr, S.J., 2010. Designer laccases: a vogue for high-potential fungal enzymes? Trends Biotechnol. 28, 63-72.

Rodríguez-Couto, S., 2016. Potential of White-Rot Fungi to Treat Xenobiotic-Containing Wastewater, in: Purchase, D. (Ed.), Fungal Applications in Sustainable Environmental Biotechnology. Springer Berlin, pp. 91-113. (ISBN: 978-113-319-42850-42855).

Roehr, M., Kubicek, C.P., Komínek, J., 2008. Citric acid, in: Rehm, H.J., Reed, G. (Eds.), Biotechnology Set, 2nd ed. John Wiley \& Sons, USA, pp. 307-345. (ISBN: 9783527620999).

Rouches, E., Herpoël-Gimbert, I., Steyer, J., Carrere, H., 2016. Improvement of anaerobic degradation by white-rot fungi pretreatment of lignocellulosic biomass: A review. Renew. Sustainable Energy Rev. 59, 179-198.

Ruijssenaars, H., Hartmans, S., 2004. A cloned Bacillus halodurans multicopper oxidase exhibiting alkaline laccase activity. Appl. Microbiol. Biotechnol. 65, 177-182.

Sadhasivam, S., Savitha, S., Swaminathan, K., Lin, F.-H., 2008. Production, purification and characterization of mid-redox potential laccase from a newly isolated Trichoderma harzianum WL1. Process Biochem. 43, 736-742.

Saha, B., Taylor, K., Bewtra, J., Biswas, N., 2010. Laccase-catalyzed removal of phenol and benzenediols from wastewater. Journal of Hazardous, Toxic, and Radioactive Waste 15, 13-20.

Sakurai, A., Masuda, M., Sakakibara, M., 2003. Effect of surfactants on phenol removal by the method of polymerization and precipitation catalysed by Coprinus cinereus peroxidase. J. Chem. Technol.

Biotechnol. 78, 952-958.

Schmidt, G., Krings, U., Nimtz, M., Berger, R.G., 2012. A surfactant tolerant laccase of Meripilus giganteus. W. J. Microbio. Biotechnol. 28, 1623-1632.

Shleev, S., Reimann, C.T., Serezhenkov, V., Burbaev, D., Yaropolov, A.I., Gorton, L., Ruzgas, T., 2006. Autoreduction and aggregation of fungal laccase in solution phase: possible correlation with a resting form of laccase. Biochimie 88, 1275-1285.

Si, J., Peng, F., Cui, B., 2013. Purification, biochemical characterization and dye decolorization capacity of an alkali-resistant and metal-tolerant laccase from Trametes pubescens. Bioresour. Technol. 128, 4957.

Sigoillot, J.-C., Berrin, J.-G., Bey, M., Lesage-Meessen, L., Levasseur, A., Lomascolo, A., Record, E., Uzan-Boukhris, E., 2012. Fungal strategies for lignin degradation, in: Jouanin, L., Lapierre, C. (Eds.), Adv. Bot. Res. Elsevier, London, pp. 263-308. (ISBN: 9780124160231).

Singhal, A., Choudhary, G., Thakur, I.S., 2012. Characterization of laccase activity produced by Cryptococcus albidus. Prep. Biochem. Biotechnol. 42, 113-124.

Sirim, D., Wagner, F., Wang, L., Schmid, R.D., Pleiss, J., 2011. The Laccase Engineering Database: a classification and analysis system for laccases and related multicopper oxidases. Database 2011. 
Sondhi, S., Sharma, P., Saini, S., Puri, N., Gupta, N., 2014. Purification and characterization of an extracellular, thermo-alkali-stable, metal tolerant laccase from Bacillus tequilensis SN4. PloS One 9, e96951.

Spina, F., Cordero, C., Schilirò, T., Sgorbini, B., Pignata, C., Gilli, G., Bicchi, C., Varese, G.C., 2015. Removal of micropollutants by fungal laccases in model solution and municipal wastewater: evaluation of estrogenic activity and ecotoxicity. J. Clean. Prod. 100, 185-194.

Spina, F., Varese, G.C., 2016. Fungal Bioremediation of Emerging Micropollutants in Municipal Wastewaters, in: Purchase, D. (Ed.), Fungal Applications in Sustainable Environmental Biotechnology. Springer, Berlin, pp. 115-141. (ISBN: 9783319428529).

Stajić, M., Vukojević, J., Knežević, A., Milovanović, I., 2013. Influence of trace elements on ligninolytic enzyme activity of Pleurotus ostreatus and P. pulmonarius. BioResources 8, 3027-3037.

Sugiyama, M., 1992. Role of physiological antioxidants in chromium (VI)-induced cellular injury. Free Radical Biol. Med. 12, 397-407.

Sun, J., Li, W., Li, Y., Hu, Y., Zhang, Y., 2013. Redox mediator enhanced simultaneous decolorization of azo dye and bioelectricity generation in air-cathode microbial fuel cell. Bioresour. Technol. 142, 407-414.

Sun, K., Kang, F., Waigi, M.G., Gao, Y., Huang, Q., 2017. Laccase-mediated transformation of triclosan in aqueous solution with metal cations and humic acid. Environ. Pollut. 220, Part A, 105-111.

Sun, K., Luo, Q., Gao, Y., Huang, Q., 2016. Laccase-catalyzed reactions of 17ß-estradiol in the presence of humic acid: Resolved by high-resolution mass spectrometry in combination with $13 \mathrm{C}$ labeling. Chemosphere 145, 394-401.

Tang, W.-W., Zeng, G.-M., Gong, J.-L., Liang, J., Xu, P., Zhang, C., Huang, B.-B., 2014. Impact of humic/fulvic acid on the removal of heavy metals from aqueous solutions using nanomaterials: a review. Sci. Total Environ. 468, 1014-1027.

Taxiarchou, M., Douni, I., 2014. The effect of oxalic acid activation on the bleaching properties of a bentonite from Milos Island, Greece. Clay Miner. 49, 541-549.

Thongkred, P., Lotrakul, P., Prasongsuk, S., Imai, T., Punnapayak, H., 2011. Oxidation of polycyclic aromatic hydrocarbons by a tropical isolate of Pycnoporus coccineus and its laccase. Scienceasia 37, 225233.

Tortella, G., Durán, N., Rubilar, O., Parada, M., Diez, M., 2015. Are white-rot fungi a real biotechnological option for the improvement of environmental health? Crit. Rev. Biotechnol. 35, 165172.

Tran, N.H., Hu, J., Urase, T., 2013. Removal of the insect repellent N, N-diethyl-m-toluamide (DEET) by laccase-mediated systems. Bioresour. Technol. 147, 667-671.

Tran, N.H., Urase, T., Kusakabe, O., 2010. Biodegradation characteristics of pharmaceutical substances by whole fungal culture Trametes versicolor and its laccase. J. water environ. technol. 8, 125-140.

Ullrich, R., Dung, N.L., Hofrichter, M., 2005. Laccase from the medicinal mushroom Agaricus blazei: production, purification and characterization. Appl. Microbiol. Biotechnol. 67, 357-363.

Valko, M., Rhodes, C., Moncol, J., Izakovic, M., Mazur, M., 2006. Free radicals, metals and antioxidants in oxidative stress-induced cancer. Chem.-Biol. Interact. 160, 1-40.

Vite-Vallejo, O., Palomares, L.A., Dantán-González, E., Ayala-Castro, H.G., Martínez-Anaya, C., Valderrama, B., Folch-Mallol, J., 2009. The role of N-glycosylation on the enzymatic activity of a Pycnoporus sanguineus laccase. Enzyme Microb. Technol. 45, 233-239.

Wagner, M., Nicell, J.A., 2002. Impact of dissolved wastewater constituents on peroxidase-catalyzed treatment of phenol. J. Chem. Technol. Biotechnol. 77, 419-428. 
Wan, J., Zeng, G., Huang, D., Huang, C., Lai, C., Li, N., Wei, Z., Xu, P., He, X., Lai, M., 2015. The oxidative stress of Phanerochaete chrysosporium against lead toxicity. Appl. Biochem. Biotechnol. 175, 1981-1991.

Wang, H.X., Ng, T.B., 2004. A novel laccase with fair thermostability from the edible wild mushroom (Albatrella dispansus). Biochem. Biophys. Res. Commun. 319, 381-385.

Wang, J., Majima, N., Hirai, H., Kawagishi, H., 2012. Effective removal of endocrine-disrupting compounds by lignin peroxidase from the white-rot fungus Phanerochaete sordida YK-624. Curr. Microbiol. 64, 300-303.

Wang, Z.-X., Cai, Y.-J., Liao, X.-R., Tao, G.-J., Li, Y.-Y., Zhang, F., Zhang, D.-B., 2010. Purification and characterization of two thermostable laccases with high cold adapted characteristics from Pycnoporus sp. SYBC-L1. Process Biochem. 45, 1720-1729.

Wen, X., Jia, Y., Li, J., 2010. Enzymatic degradation of tetracycline and oxytetracycline by crude manganese peroxidase prepared from Phanerochaete chrysosporium. J. Hazard. Mater. 177, 924-928.

Xu, F., 1996. Oxidation of phenols, anilines, and benzenethiols by fungal laccases: correlation between activity and redox potentials as well as halide inhibition. Biochemistry 35, 7608-7614.

$\mathrm{Xu}, \mathrm{F} ., 1997$. Effects of redox potential and hydroxide inhibition on the $\mathrm{pH}$ activity profile of fungal laccases. J. Biol. Chem. 272, 924-928.

Yang, M., Yu, X.-W., Zheng, H., Sha, C., Zhao, C., Qian, M., Xu, Y., 2015. Role of N-linked glycosylation in the secretion and enzymatic properties of Rhizopus chinensis lipase expressed in Pichia pastoris. Microb. Cell Fact. 14, 1.

Yang, S., Hai, F.I., Nghiem, L.D., Nguyen, L.N., Roddick, F., Price, W.E., 2013a. Removal of bisphenol A and diclofenac by a novel fungal membrane bioreactor operated under non-sterile conditions. Int. Biodeterior. Biodegrad. 85, 483-490.

Yang, S., Hai, F.I., Nghiem, L.D., Price, W.E., Roddick, F., Moreira, M.T., Magram, S.F., 2013 b. Understanding the factors controlling the removal of trace organic contaminants by white-rot fungi and their lignin modifying enzymes: a critical review. Bioresour. Technol. 141, 97-108.

Yang, S., Hai, F.I., Nghiem, L.D., Roddick, F., Price, W.E., 2013c. Removal of trace organic contaminants by nitrifying activated sludge and whole-cell and crude enzyme extract of Trametes versicolor. Wat. Sci. Tech. 67, 1216-1223.

Zavarzina, A.G., Leontievsky, A.A., Golovleva, L.A., Trofimov, S.Y., 2004. Biotransformation of soil humic acids by blue laccase of Panus tigrinus 8/18: an in vitro study. Soil Biol. Biochem. 36, 359-369.

Zeng, G.-M., Chen, A.-W., Chen, G.-Q., Hu, X.-J., Guan, S., Shang, C., Lu, L.-H., Zou, Z.-J., 2012.

Responses of Phanerochaete chrysosporium to toxic pollutants: physiological flux, oxidative stress, and detoxification. Environ. Sci. Technol. 46, 7818-7825.

Zeng, G., Li, N., Huang, D., Lai, C., Zhao, M., Huang, C., Wei, Z., Xu, P., Zhang, C., Cheng, M., 2015. The stability of $\mathrm{Pb}$ species during the $\mathrm{Pb}$ removal process by growing cells of Phanerochaete chrysosporium. Appl. Microbiol. Biotechnol. 99, 3685-3693.

Zhang, H., Zhang, S., He, F., Qin, X., Zhang, X., Yang, Y., 2016. Characterization of a manganese peroxidase from white-rot fungus Trametes sp. 48424 with strong ability of degrading different types of dyes and polycyclic aromatic hydrocarbons. J. Hazard. Mater. 320, 265-277.

Zhang, J., Liu, X., Xu, Z., Chen, H., Yang, Y., 2008. Degradation of chlorophenols catalyzed by laccase. Int. Biodeterior. Biodegrad. 61, 351-356.

Zhang, Q., Zeng, G., Chen, G., Yan, M., Chen, A., Du, J., Huang, J., Yi, B., Zhou, Y., He, X., 2015. The Effect of Heavy Metal-Induced Oxidative Stress on the Enzymes in White Rot Fungus Phanerochaete chrysosporium. Appl. Biochem. Biotechnol. 175, 1281-1293. 
Zhang, Y., Geißen, S.-U., 2012. Elimination of carbamazepine in a non-sterile fungal bioreactor. Bioresour. Technol. 112, 221-227.

Zhang, Y., Zeng, Z., Zeng, G., Liu, X., Liu, Z., Chen, M., Liu, L., Li, J., Xie, G., 2012. Effect of Triton $\mathrm{X}-100$ on the removal of aqueous phenol by laccase analyzed with a combined approach of experiments and molecular docking. Colloids Surf. B. Biointerfaces 97, 7-12.

Zhang, Y.L., Zhang, H.B., Zhu, Y.S., Cao, M.L., Ai, M.Q., Huang, F., 2013. Influences of Organic Compounds on Laccase Activity Tests, Applied Mechanics and Materials. Trans Tech. Publications, pp. 1702-1707. 


\section{List of Tables}

Table 1. Characteristics of extracellular ligninolytic enzymes (compiled from Dashtban et al., 2010; Sigoillot et al., 2012)

Table 2. Minimum range of concentration for inorganic interfering compounds to cause 20 $\left(\mathrm{IC}_{20}\right), 50\left(\mathrm{IC}_{50}\right)$ and $100 \%\left(\mathrm{IC}_{100}\right)$ laccase inactivation.

Table 3. Normalized inhibition (\% per min) of purified laccases from different WRF species in the presence of organic interfering compounds. 
Table 1: Characteristics of extracellular ligninolytic enzymes (compiled from Dashtban et al., 2010; Sigoillot et al., 2012)

\begin{tabular}{lccccc}
\hline \multicolumn{1}{c}{$\begin{array}{c}\text { Ligninolytic } \\
\text { enzymes }\end{array}$} & $\begin{array}{c}\text { Molecular } \\
\text { mass } \\
(\mathbf{K D a})\end{array}$ & $\begin{array}{c}\text { Redox } \\
\text { potential } \\
(\mathbf{m V})\end{array}$ & $\begin{array}{c}\text { Glycosylation } \\
(\boldsymbol{\%})\end{array}$ & $\begin{array}{c}\text { Isoelectric } \\
\text { point }\end{array}$ & Cofactor \\
\hline Laccase & $50-80$ & $0.3-0.8$ & $\begin{array}{l}10-20(\mathrm{~N}- \\
\text { Glycosylated })\end{array}$ & $3-4$ & $\mathrm{O}_{2}$ \\
Lignin peroxidase & $35-48$ & $1-1.2$ & $\begin{array}{l}20-30(\mathrm{~N}- \\
\text { Glycosylated })\end{array}$ & $3.1-4.5$ & $\mathrm{H}_{2} \mathrm{O}_{2}$ \\
$\begin{array}{l}\text { Manganese } \\
\text { peroxidase }\end{array}$ & $38-62$ & $0.8-1$ & $\begin{array}{l}5-15(\mathrm{~N}- \\
\text { Glycosylated })\end{array}$ & $3-7.2$ & $\mathrm{H}_{2} \mathrm{O}_{2}$ \\
$\begin{array}{l}\text { Versatile } \\
\text { peroxidase }\end{array}$ & $40-47$ & $>1$ & N.A. & $3.4-4.9$ & $\mathrm{H}_{2} \mathrm{O}_{2}$ \\
\hline
\end{tabular}

"N.A.": not available 
Table 2. Minimum range of concentration for inorganic interfering compounds to cause $20\left(\mathrm{IC}_{20}\right), 50$ $\left(\mathrm{IC}_{50}\right)$ and $100 \%\left(\mathrm{IC}_{100}\right)$ laccase inactivation.

\begin{tabular}{|c|c|c|c|c|}
\hline \multirow{2}{*}{$\begin{array}{l}\text { Inorganic interfering } \\
\text { compounds }\end{array}$} & \multicolumn{3}{|c|}{ Inhibitory concentrations (mM) } & \multirow[t]{2}{*}{ Selected references } \\
\hline & $\mathrm{IC}_{20}$ & $\mathrm{IC}_{50}$ & $\mathrm{IC}_{100}$ & \\
\hline $\mathrm{NaCl}$ & $3-5$ & $10-25$ & $>100$ & $\begin{array}{l}\text { Ramírez-Cavazos et al. (2014); } \\
\text { Wang et al. (2010); Schmidt et } \\
\text { al. (2012) }\end{array}$ \\
\hline $\mathrm{KCl}$ & $3-5$ & $8-10$ & - & $\begin{array}{l}\text { Wang et al. (2010); Murugesan } \\
\text { et al. (2009); Kumar et al. (2012) }\end{array}$ \\
\hline $\mathrm{LiCl}$ & $5-8$ & $>10$ & - & Murugesan et al. (2009) \\
\hline $\mathrm{CuSO}_{4}$ & $2-5$ & $5-25$ & - & $\begin{array}{l}\text { Lorenzo et al. (2005); Sun et al. } \\
\text { (2017); Schmidt et al. (2012); } \\
\text { Kumar and Srikumar (2012) }\end{array}$ \\
\hline $\mathrm{MnSO}_{4}$ & $4-8$ & $10-25$ & - & $\begin{array}{l}\text { Ademakinwa and Agboola } \\
\text { (2016); Farnet et al. (2008); } \\
\text { Schmidt et al. (2012) }\end{array}$ \\
\hline $\mathrm{CdCl}_{2}$ & $8-10$ & $11-15$ & $>40$ & $\begin{array}{l}\text { Murugesan et al. (2009); Kumar } \\
\text { et al. (2012); Murugesan et al. } \\
\text { (2009) }\end{array}$ \\
\hline $\mathrm{CaCl}_{2}$ & $2-5$ & $8-10$ & $>20$ & $\begin{array}{l}\text { Cabana et al. (2007); Cabana et } \\
\text { al. (2009); Schmidt et al. (2012); } \\
\text { Ademakinwa and Agboola } \\
\text { (2016) }\end{array}$ \\
\hline $\mathrm{CoCl}_{2}$ & $1-4$ & $5-8$ & $>50$ & $\begin{array}{l}\text { Cabana et al. (2009); Wang et al. } \\
\text { (2010); Sadhasivam et al. } \\
\text { (2008); Ademakinwa and } \\
\text { Agboola (2016); Murugesan et } \\
\text { al. (2009) }\end{array}$ \\
\hline $\mathrm{MgCl}_{2} / \mathrm{MgSO}_{4}$ & $4-7$ & $8-10$ & - & $\begin{array}{l}\text { Kumar et al. (2012); Kumar and } \\
\text { Srikumar (2012); Sadhasivam et } \\
\text { al. (2008); Ademakinwa and } \\
\text { Agboola (2016) }\end{array}$ \\
\hline $\mathrm{FeCl}_{2} / \mathrm{FeSO}_{4}$ & - & $\leq 1$ & $2-5$ & $\begin{array}{l}\text { Sun et al. (2017); Kumar and } \\
\text { Srikumar (2012); Thongkred et } \\
\text { al. (2011); Wang et al. (2010) }\end{array}$ \\
\hline $\mathrm{NiCl}_{2}$ & $5-9$ & $10-15$ & $>50$ & $\begin{array}{l}\text { Murugesan et al. (2009); } \\
\text { Ademakinwa and Agboola }\end{array}$ \\
\hline
\end{tabular}




\begin{tabular}{|c|c|c|c|c|}
\hline \multirow{2}{*}{$\begin{array}{l}\text { Inorganic interfering } \\
\text { compounds }\end{array}$} & \multicolumn{3}{|c|}{ Inhibitory concentrations (mM) } & \multirow[t]{2}{*}{ Selected references } \\
\hline & $\mathrm{IC}_{20}$ & $\mathrm{IC}_{50}$ & $\mathrm{IC}_{100}$ & \\
\hline & & & & (2016) \\
\hline $\mathrm{HgCl}_{2}$ & $<0.5$ & $0.5-1$ & $>10$ & $\begin{array}{l}\text { Murugesan et al. (2009); Farnet } \\
\text { et al. (2008); Kumar et al. } \\
\text { (2012); Sadhasivam et al. (2008) }\end{array}$ \\
\hline $\mathrm{BaCl}_{2}$ & $\leq 1$ & $2-5$ & $>10$ & $\begin{array}{l}\text { Sadhasivam et al. (2008); Wang } \\
\text { et al. (2010) }\end{array}$ \\
\hline $\mathrm{PbCl}_{2}$ & - & $<2$ & $8-15$ & Kumar et al. (2012) \\
\hline $\mathrm{SnCl}_{2}$ & $\leq 5$ & - & - & Sadhasivam et al. (2008) \\
\hline $\mathrm{AlCl}_{3}$ & $0.5-1$ & $5-10$ & - & $\begin{array}{l}\text { Wang et al. (2010); Sun et al. } \\
\text { (2017) }\end{array}$ \\
\hline $\mathrm{K}_{2} \mathrm{CrO}_{4}$ & - & $\leq 0.5$ & $1-5$ & $\begin{array}{l}\text { Sadhasivam et al. (2008); } \\
\text { Murugesan et al. (2009) }\end{array}$ \\
\hline $\mathrm{NaF}$ & & $0.01-0.05$ & $5-15$ & $\begin{array}{l}\text { Ramírez-Cavazos et al. (2014); } \\
\text { Farnet et al. (2008) }\end{array}$ \\
\hline $\mathrm{NaI}$ & - & $15-25$ & - & $\begin{array}{l}\text { Ramírez-Cavazos et al. (2014); } \\
\text { Farnet et al. (2008) }\end{array}$ \\
\hline $\mathrm{NaN}_{3}$ & - & $\leq 0.005$ & $0.5-5$ & $\begin{array}{l}\text { Singhal et al. (2012); Kumar and } \\
\text { Srikumar (2012); Ramírez- } \\
\text { Cavazos et al. (2014); } \\
\text { Ademakinwa and Agboola } \\
\text { (2016) }\end{array}$ \\
\hline
\end{tabular}


Table 3. Normalized inhibition (\% per min) of purified laccases from different WRF species in the presence of organic interfering compounds.

\begin{tabular}{|c|c|c|c|c|c|c|}
\hline $\begin{array}{l}\text { Organic } \\
\text { interfering } \\
\text { compounds }\end{array}$ & Concentration & $\begin{array}{l}\text { Purified laccase } \\
\text { WRF source }\end{array}$ & $\begin{array}{c}\text { Experimental } \\
\text { conditions } \\
\text { (pH/Temp./ } \\
\text { incubation time) }\end{array}$ & $\begin{array}{c}\text { Substrate for } \\
\text { enzymatic activity }\end{array}$ & Normalized Inhibition & References \\
\hline & $(\mathrm{mM})$ & & Units $/{ }^{\circ} \mathrm{C} / \mathrm{min}$ & & $(\%$ per $\min )$ & \\
\hline \multirow[t]{12}{*}{ EDTA } & 0.01 & $\begin{array}{l}\text { C. polyzona } \\
\text { (MUCL 38443) }\end{array}$ & $3.0 / 20 / 30$ & ABTS & 2 & Cabana et al. (2009) \\
\hline & 0.01 & $\begin{array}{l}\text { C. polyzona } \\
\text { (MUCL 38443) }\end{array}$ & $3.0 / 20 / 30$ & ABTS & 1.97 & Cabana et al. (2007) \\
\hline & $0.1,1$ & C. pterogonus & $10 / 60 / 30$ & DMP & $2.33,3.27$ & $\begin{array}{l}\text { Kumar and Srikumar } \\
(2012)\end{array}$ \\
\hline & $0.1,1$ & O. vulgaris & $10 / 60 / 30$ & DMP & $2.13,3.33$ & $\begin{array}{l}\text { Kumar and Srikumar } \\
(2012)\end{array}$ \\
\hline & $0.05,0.5,2.5$ & A. pullulans NAC8 & $5 / 25 / 15$ & Guaiacol & $1.13,1.93,1.87$ & $\begin{array}{l}\text { Ademakinwa and } \\
\text { Agboola (2016) }\end{array}$ \\
\hline & $0.1,0.5,25,50$ & M. giganteus & $3.0 / 30 / 15$ & ABTS & $0,0.67,1,1.33$ & Schmidt et al. (2012) \\
\hline & $1,5,10$ & $\begin{array}{l}\text { Pycnoporus sp. } \\
\text { SYBC-L1 }\end{array}$ & $3 / 30 / 5$ & ABTS & $+1,2,3.8$ & Wang et al. (2010) \\
\hline & $1,5,10,25$ & T. harzianum WL1 & $4.5 / 35 / 30$ & ABTS & $0.57,1.33,2.1,3.17$ & Sadhasivam et al. (2008) \\
\hline & $2,20,30,60,80$ & T. versicolor $\mathrm{CBS}$ & $4.5 / 25 / 2$ & $\begin{array}{c}\text { DMP/ } \\
\text { Syringaldazine }\end{array}$ & $\begin{array}{l}5,10,17.5,20, \\
22.5(\mathrm{DMP}) / 10,12.5, \\
15,17.5,20 \\
\text { (syringaldazine) }\end{array}$ & Lorenzo et al. (2005) \\
\hline & 10,100 & P. ostreatus & $5 / 30 / 30$ & ABTS & $0.97,2.57$ & Kumar et al. (2012) \\
\hline & 49,100 & $P$. sanguineus & $3 / 25 / 5$ & ABTS & 10,20 & $\begin{array}{l}\text { Ramírez-Cavazos et al. } \\
\text { (2014) }\end{array}$ \\
\hline & $0-1 \%$ & C. albidus & $2.5 / 30 / 5$ & ABTS & No inhibition & Singhal et al. (2012) \\
\hline \multirow[t]{2}{*}{ Oxalic acid } & $\begin{array}{l}2,8,16(\mathrm{DMP}) / 2,8 \\
\text { (syringaldazine) }\end{array}$ & T. versicolor $\mathrm{CBS}$ & $4.5 / 25 / 2$ & $\begin{array}{c}\text { DMP/ } \\
\text { Syringaldazine }\end{array}$ & $\begin{array}{l}10,20,47.5(\mathrm{DMP}) / \\
12.5,50 \\
\text { (syringaldazine) }\end{array}$ & Lorenzo et al. (2005) \\
\hline & 5 & A. pullulans NAC8 & $5 / 25 / 15$ & Guaiacol & 6.4 & Ademakinwa and \\
\hline
\end{tabular}




\begin{tabular}{|c|c|c|c|c|c|c|}
\hline & & & & & & Agboola (2016) \\
\hline & 10,100 & P. ostreatus & $5 / 30 / 30$ & ABTS & $0.33,3$ & Kumar et al. (2012) \\
\hline \multirow[t]{2}{*}{ Citric acid } & $\begin{array}{l}2,8,16(\mathrm{DMP}) / 0.5, \\
2,4 \text { (syringaldazine) }\end{array}$ & T. versicolor $\mathrm{CBS}$ & $4.5 / 25 / 2$ & $\begin{array}{c}\text { DMP/ } \\
\text { Syringaldazine }\end{array}$ & $\begin{array}{l}12.5,17.5,49.5 \text { (DMP); } \\
20,35,50 \\
\text { (syringaldazine) }\end{array}$ & Lorenzo et al. (2005) \\
\hline & 10,100 & P. ostreatus & $5 / 30 / 30$ & ABTS & $2.23,3.33$ & Kumar et al. (2012) \\
\hline \multirow[t]{5}{*}{ Methanol } & $10,50 \%(\mathrm{v} / \mathrm{v})$ & A. pullulans NAC8 & $5 / 25 / 15$ & Guaiacol & 2,5 & $\begin{array}{l}\text { Ademakinwa and } \\
\text { Agboola (2016) }\end{array}$ \\
\hline & $\begin{array}{l}10,20,30,40,50 \% \\
(\mathrm{v} / \mathrm{v})\end{array}$ & C. albidus & $2.5 / 30 / 5$ & ABTS & $8,15,17,19,20$ & Singhal et al. (2012) \\
\hline & $25 \%(\mathrm{v} / \mathrm{v})$ & $\begin{array}{l}\text { C. polyzona } \\
\text { (MUCL 38443) }\end{array}$ & $3.0 / 20 / 30$ & ABTS & 1.67 & Cabana et al. (2009) \\
\hline & $25 \%(\mathrm{v} / \mathrm{v})$ & $\begin{array}{l}\text { C. polyzona } \\
\text { (MUCL 38443) }\end{array}$ & $3.0 / 20 / 30$ & ABTS & 1.67 & Cabana et al. (2007) \\
\hline & $\begin{array}{l}25,35,45,65,80 \% \\
(\mathrm{v} / \mathrm{v})\end{array}$ & M. quercophilus & $4 / 25 / 2$ & ABTS & $10,20,30,40,50$ & Farnet et al. (2008) \\
\hline \multirow[t]{6}{*}{ Acetone } & $10,50 \%(\mathrm{v} / \mathrm{v})$ & A. pullulans NAC8 & $5 / 25 / 15$ & Guaiacol & $1.33,6$ & $\begin{array}{l}\text { Ademakinwa and } \\
\text { Agboola (2016) }\end{array}$ \\
\hline & $\begin{array}{l}10,20,30,40,50 \% \\
(\mathrm{v} / \mathrm{v})\end{array}$ & C. albidus & $2.5 / 30 / 5$ & ABTS & $8,15,17,19,20$ & Singhal et al. (2012) \\
\hline & $25 \%(\mathrm{v} / \mathrm{v})$ & $\begin{array}{l}\text { C. polyzona } \\
\text { (MUCL 38443) }\end{array}$ & $3.0 / 20 / 30$ & ABTS & 1.33 & Cabana et al. (2009) \\
\hline & $25 \%(\mathrm{v} / \mathrm{v})$ & $\begin{array}{l}\text { C. polyzona } \\
\text { (MUCL 38443) }\end{array}$ & $3.0 / 20 / 30$ & ABTS & 1.77 & Cabana et al. (2007) \\
\hline & $\begin{array}{l}25,35,45,65,80 \% \\
(\mathrm{v} / \mathrm{v})\end{array}$ & M. quercophilus & $4 / 25 / 2$ & ABTS & $7.5,27.5,30,40,50$ & Farnet et al. (2008) \\
\hline & $47,72 \%(\mathrm{v} / \mathrm{v})$ & P. sanguineus & $3 / 25 / 5$ & ABTS & 10,20 & $\begin{array}{l}\text { Ramírez-Cavazos et al. } \\
\text { (2014) }\end{array}$ \\
\hline \multirow[t]{4}{*}{ Ethanol } & $10,20,50,70(\mathrm{v} / \mathrm{v})$ & T. harzianum WL1 & $4.5 / 35 / 30$ & ABTS & $0.11,0.3,1.63,3.33$ & Sadhasivam et al. (2008) \\
\hline & $10,50 \%(\mathrm{v} / \mathrm{v})$ & A. pullulans NAC8 & $5 / 25 / 15$ & Guaiacol & $2.67,5.33$ & $\begin{array}{l}\text { Ademakinwa and } \\
\text { Agboola (2016) }\end{array}$ \\
\hline & $20 \%(\mathrm{v} / \mathrm{v})$ & P. ostreatus & $5 / 30 / 30$ & ABTS & 0.83 & Kumar et al. (2012) \\
\hline & $\begin{array}{l}25,35,45,65,80 \% \\
\text { (v/v) }\end{array}$ & M. quercophilus & $4 / 25 / 2$ & ABTS & $2.5,10,17.5,27.5,50$ & Farnet et al. (2008) \\
\hline
\end{tabular}




\begin{tabular}{|c|c|c|c|c|c|c|}
\hline & $55,64 \%(\mathrm{v} / \mathrm{v})$ & P. sanguineus & $3 / 25 / 5$ & ABTS & 10,20 & $\begin{array}{l}\text { Ramírez-Cavazos et al. } \\
(2014)\end{array}$ \\
\hline \multirow[t]{7}{*}{ SDS } & $0.01,0.1,1,10$ & M. giganteus & $3.0 / 30 / 15$ & ABTS & $0,0.5,6.67,6.67$ & Schmidt et al. (2012) \\
\hline & $0.05,0.5,2.5$ & A. pullulans NAC8 & $5 / 25 / 15$ & Guaiacol & $2.53,4.27,6.07$ & $\begin{array}{l}\text { Ademakinwa and } \\
\text { Agboola (2016) }\end{array}$ \\
\hline & $1,5,10$ & $\begin{array}{l}\text { Pycnoporus sp. } \\
\text { SYBC-L1 }\end{array}$ & $3 / 30 / 5$ & ABTS & $20,20,20$ & Wang et al. (2010) \\
\hline & 20,100 & O. vulgaris & $10 / 60 / 30$ & DMP & $0.5,2.83$ & $\begin{array}{l}\text { Kumar and Srikumar } \\
(2012)\end{array}$ \\
\hline & 5810,8000 & P. sanguineus & $3 / 25 / 5$ & ABTS & 10,20 & $\begin{array}{l}\text { Ramírez-Cavazos et al. } \\
(2014)\end{array}$ \\
\hline & $0.01 \%(\mathrm{v} / \mathrm{v})$ & P. ostreatus & $5 / 30 / 30$ & ABTS & 3.33 & Kumar et al. (2012) \\
\hline & $0.1-0.5 \%$ & C. albidus & $2.5 / 30 / 5$ & ABTS & No impact & Singhal et al. (2012) \\
\hline \multirow[t]{2}{*}{ Urea } & $0.1,0.5,4,8 \mathrm{M}$ & C. pterogonus & $10 / 60 / 30$ & DMP & $0,0.2,0.13,1.67$ & $\begin{array}{l}\text { Kumar and Srikumar } \\
\text { (2012) }\end{array}$ \\
\hline & $0.1,0.5,4,8 \mathrm{M}$ & O. vulgaris & $10 / 60 / 30$ & DMP & $0,0.23,0.23,1.77$ & $\begin{array}{l}\text { Kumar and Srikumar } \\
(2012)\end{array}$ \\
\hline \multirow[t]{2}{*}{ Phenol } & 1 & T. villosa & $5.6 / 25 / 180$ & Syringaldazine & 0.39 & Saha et al. (2010) \\
\hline & 5 & A. pullulans NAC8 & $5 / 25 / 15$ & Guaiacol & 6.67 & $\begin{array}{l}\text { Ademakinwa and } \\
\text { Agboola (2016) }\end{array}$ \\
\hline Humic acid & $0-50$ & P. ostreatus & $6 / 25 / 5$ & NA & No impact & Sun et al. (2017) \\
\hline
\end{tabular}

"+" indicates \% increase in enzymatic activity

"NA" indicates that information not available.

EDTA: ethylenediaminetetraacetic acid; SDS: sodium dodecyl sulfate; ABTS: 2,2'-Azino-bis(3-ethylbenzothiazoline-6-sulfonic acid); and DMP: 2,4,6-

Tris(dimethylaminomethyl)phenol 


\section{List of Figures}

Figure 1. TrOC removal mechanisms by WRF-based treatment processes (modified after Asif et al. (2017)).

Figure 2. Variations in the removal of TrOCs categorized based on their chemical structure following batch treatment with purified laccase (a), crude laccase (b) and whole-cell WRF (c). TrOCs containing electron donating groups (EDGs) in their chemical structure generally show higher removal than those containing electron withdrawing groups (EWGs). Numbers within parenthesis indicate number of data point ( $\left.\mathrm{n}_{\text {whole-cell } \mathrm{WRF}}+\mathrm{n}_{\text {crude laccase }}+\mathrm{n}_{\text {purified laccase }}\right)$. “*”: indicates TrOCs containing phenolic moiety. Complete data set for this summary graph is presented in supplementary Data Table S1.

Figure 3. Possible mechanisms of heavy metals-induced growth inhibition in WRF.

Figure 4. Inhibition and enhancement (\% per day) of WRF growth (a) and enzyme production (b) in the presence of different metals. Unless marked otherwise, the data points in (b) indicate laccase activity. Data Source: Baldrian and Gabriel (2002); Baldrian et al. (2005); Bhattacharya et al. (2014); Chen et al. (2015); Grąz et al. (2011); Hatvani and Mécs (2003); Huang et al. (2010); Khammuang et al. (2013); Li et al. (2015); Mutlu et al. (2014); Stajić et al. (2013); and Zhang et al. (2015)

Figure 5. Possible mechanisms of laccase inhibition by organic and inorganic interfering compounds.

Figure 6. Normalized inhibition (\% per min) of laccases from Coriolopsis polyzona (1), Cereus pterogonus (2), Opuntia vulgaris (3), Aureobasidium pullulans NAC8 (4), Meripilus giganteus (5), Pycnoporus sp. SYBC-L1 (6), Trichoderma harzianum WL1 (7) and Pleurotus ostreatus (8) in the presence of EDTA (a) and sodium azide (b). Negative values indicate improvement in the laccase activity. Data source: Ademakinwa and Agboola (2016); Cabana et al. (2007); Cabana et al. (2009); Kumar and Srikumar (2012); Kumar et al. (2012); Sadhasivam et al. (2008); Schmidt et al. (2012); and Wang et al. (2010).

Figure 7. Influence of incubation time on laccase inhibition by selected organic and inorganic interfering compounds at different concentrations. Negative values indicate improvement in the enzymatic activity. Data source: Ademakinwa and Agboola (2016); Farnet et al. (2008); Kumar and Srikumar (2012); Murugesan et al. (2009); Sadhasivam et al. (2008); Saha et al. (2010); Schmidt et al. (2012); Singhal et al. (2012); Thongkred et al. (2011); and Wang et al. (2010).

Figure 8. Inhibition of purified laccase caused by sulphate (a) and chloride (b) salts of different metals. Negative values indicate improvement in the enzymatic activity. Data source: Ademakinwa and Agboola (2016); Farnet et al. (2008); Kumar and Srikumar (2012); Kumar et al. (2012); Lorenzo et al. (2005); Murugesan et al. (2009); Schmidt et al. (2012); Thongkred et al. (2011); and Wang et al. (2010).

Figure 9. Impact of organic and inorganic interfering compounds on the removal of bisphenol A, triclosan and $17 \beta$-estradiol by laccase. Arrows indicate the change in impact following an increase in the concentration of the interfering compound, as noted on x-axis. Values in parenthesis shown on the plotting area indicate concentrations different to that noted on $\mathrm{x}$-axis. Negative values indicate improvement in the removal of TrOCs. Data source: Hou et al. (2014); Kim and Nicell (2006a); Kim and Nicell (2006c); Sun et al. (2016); and Sun et al. (2017). 


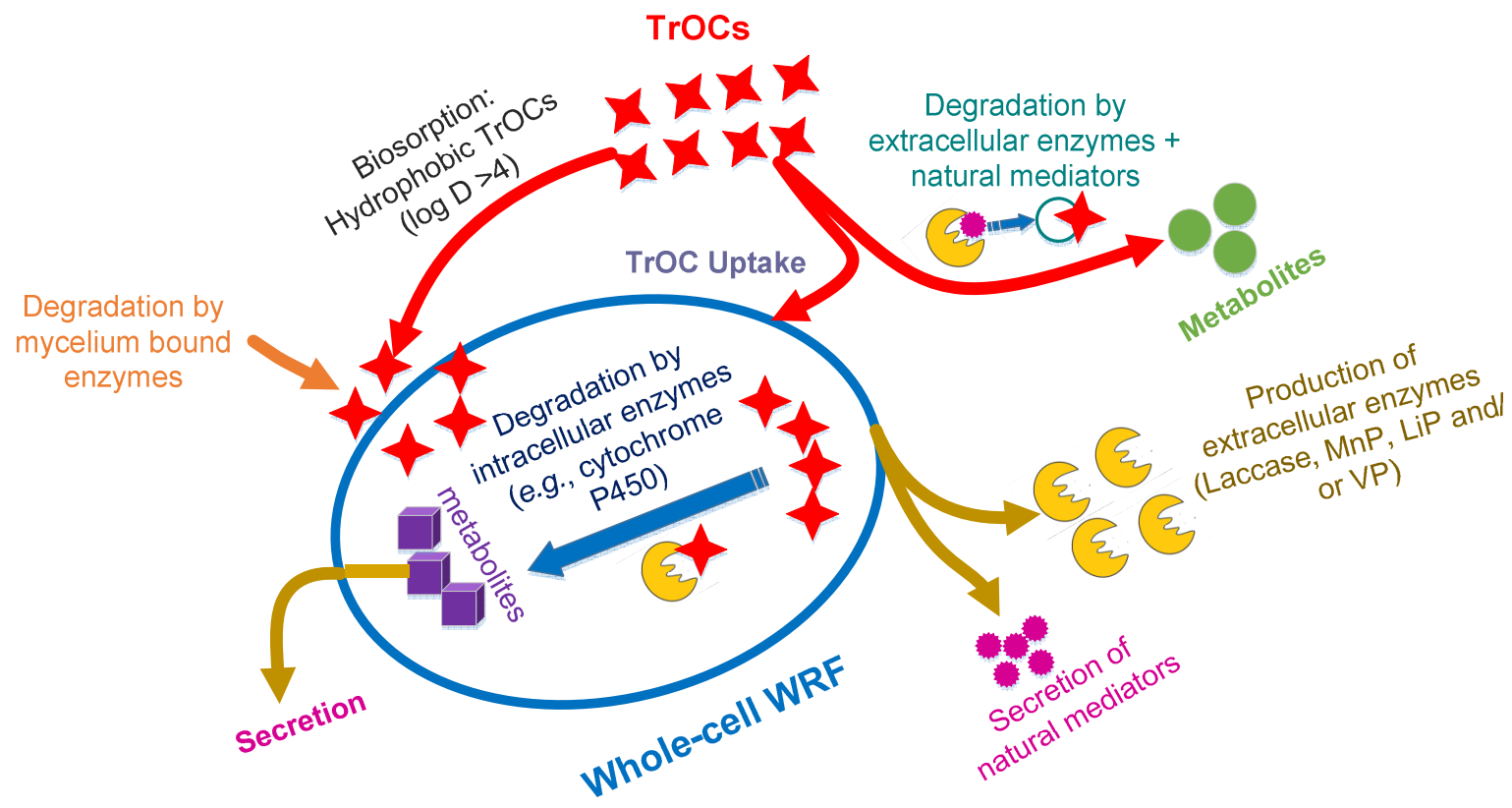

Figure 1

Page $\mathbf{5 7}$ of $\mathbf{7 6}$ 


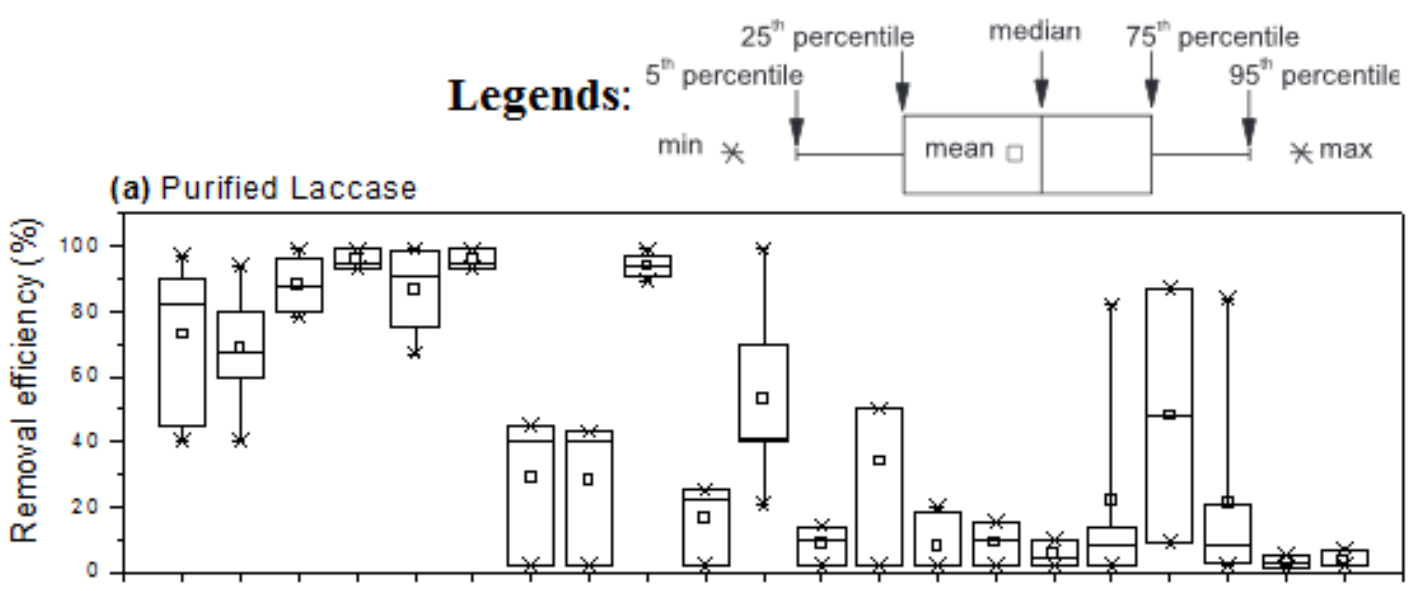

(b) Crude Laccase

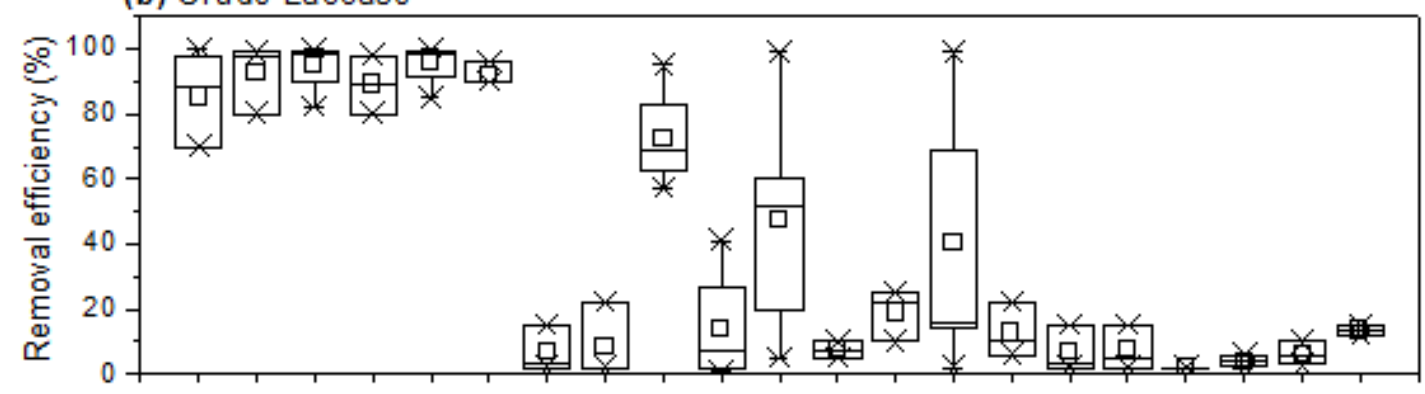

(c) Whole-cell WRF

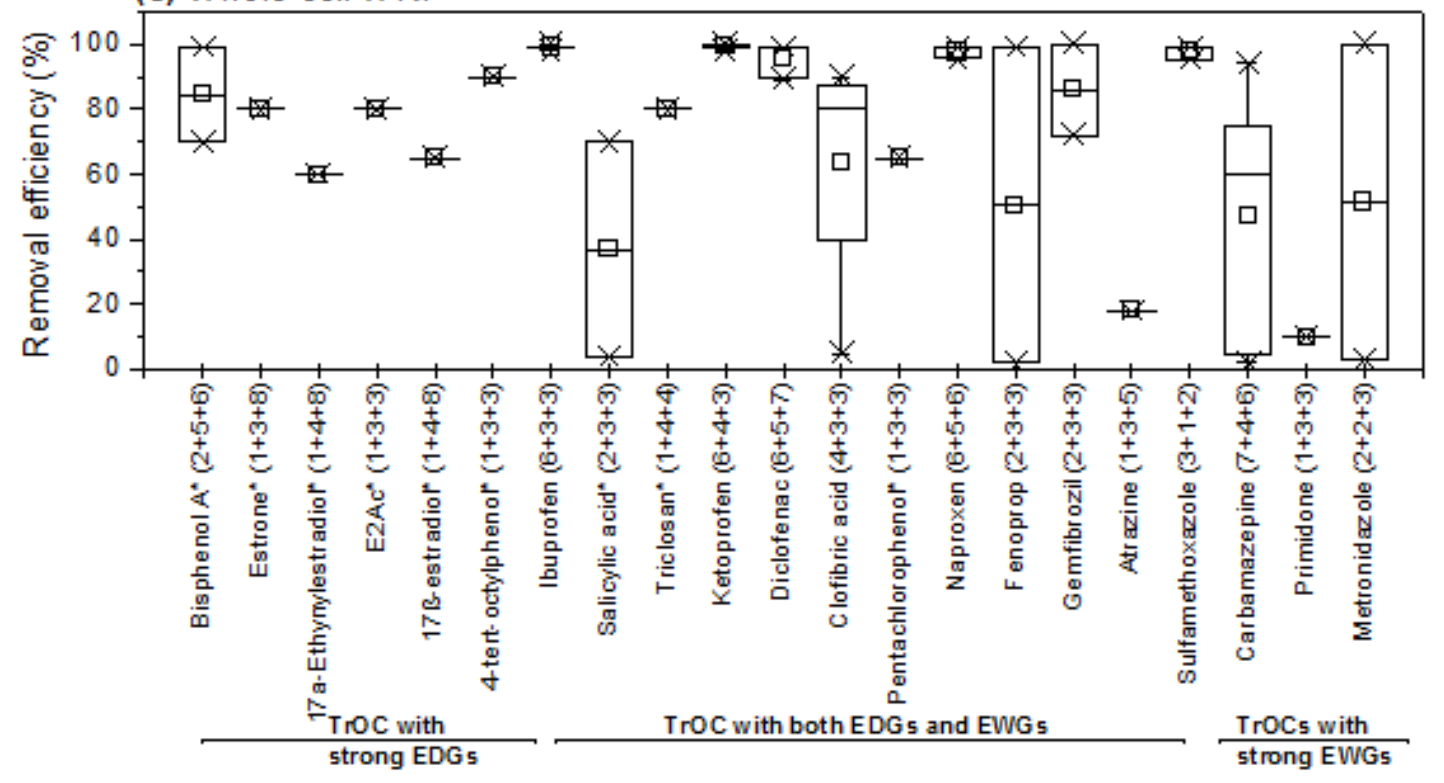

Figure 2 


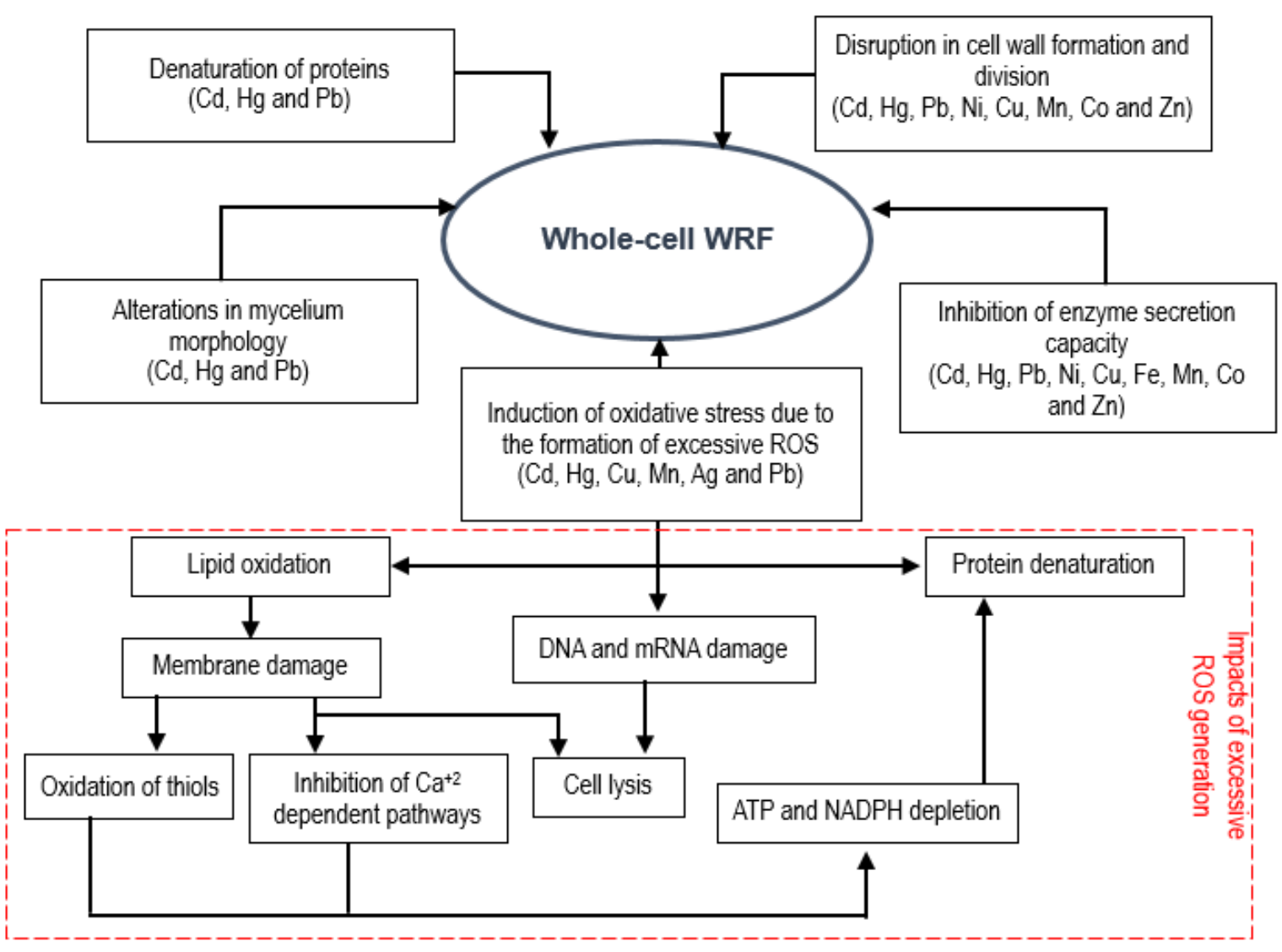

Figure 3 

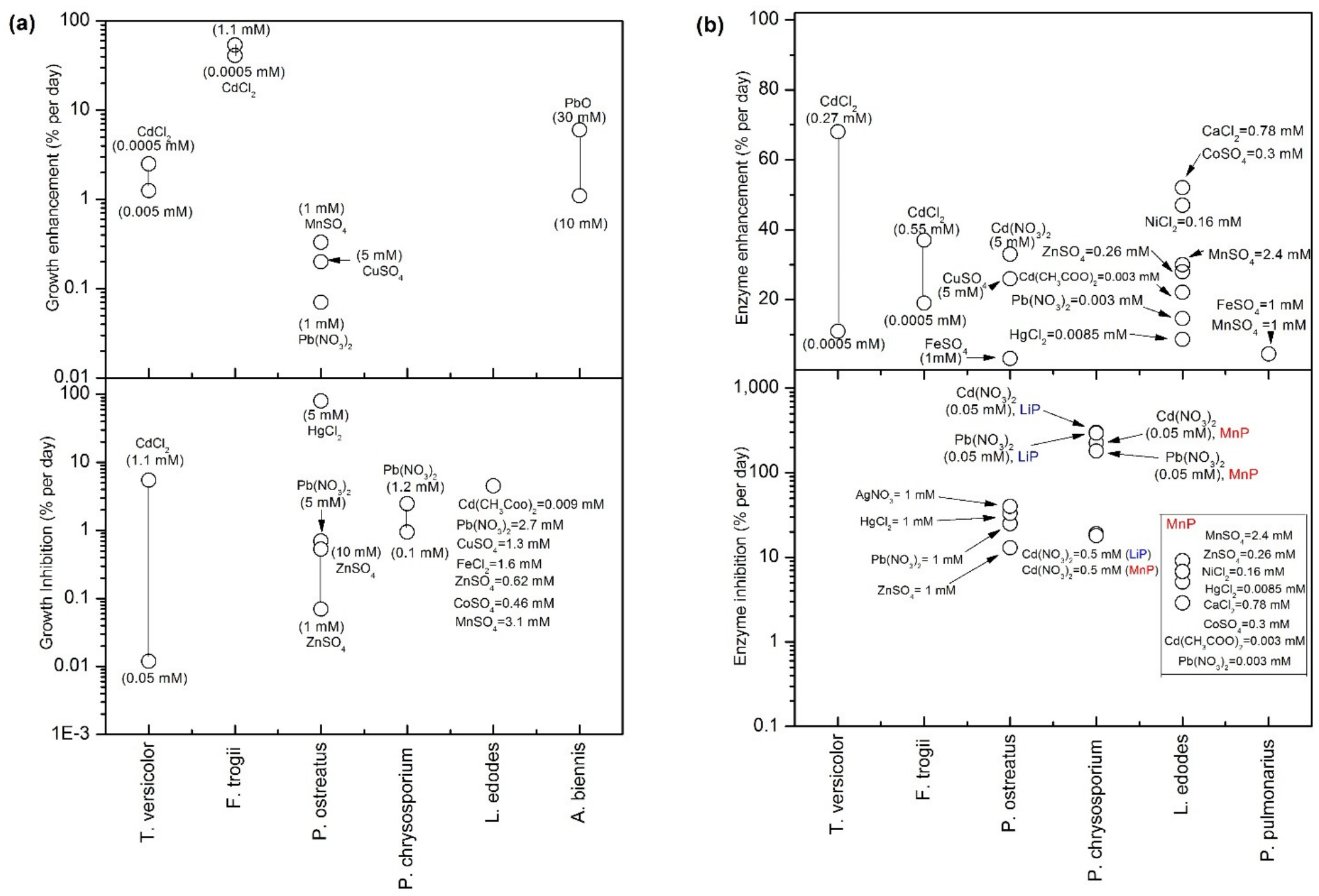

\section{Figure 4}


Impacts of Inorganic

interfering compounds

Impacts of organic

interfering compounds

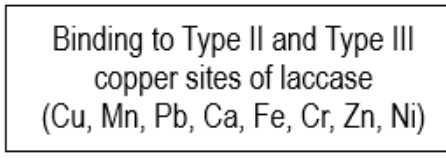

Blocking internal electron transfer (Cu, Mn, Pb, Ca, Fe, Cr, Zn, Ni)

Protein denaturation by binding to
thiol groups
$(\mathrm{Hg})$

Competitive inhibition $(\mathrm{Cl}$ and $\mathrm{Br}$ )
Competitive inhibition (EDTA, oxalic acid, citric acid, SDS and phenol)

$\mathrm{pH}$ alterations

(Oxalic acid, citric acid and organic solvents and surfactants)

Chelation of copper from enzyme active sites

(EDTA and citric acid)

Protein denaturation by attacking hydrophobic regions of enzymes (Urea and surfactants)

Figure 5 
(a) EDTA
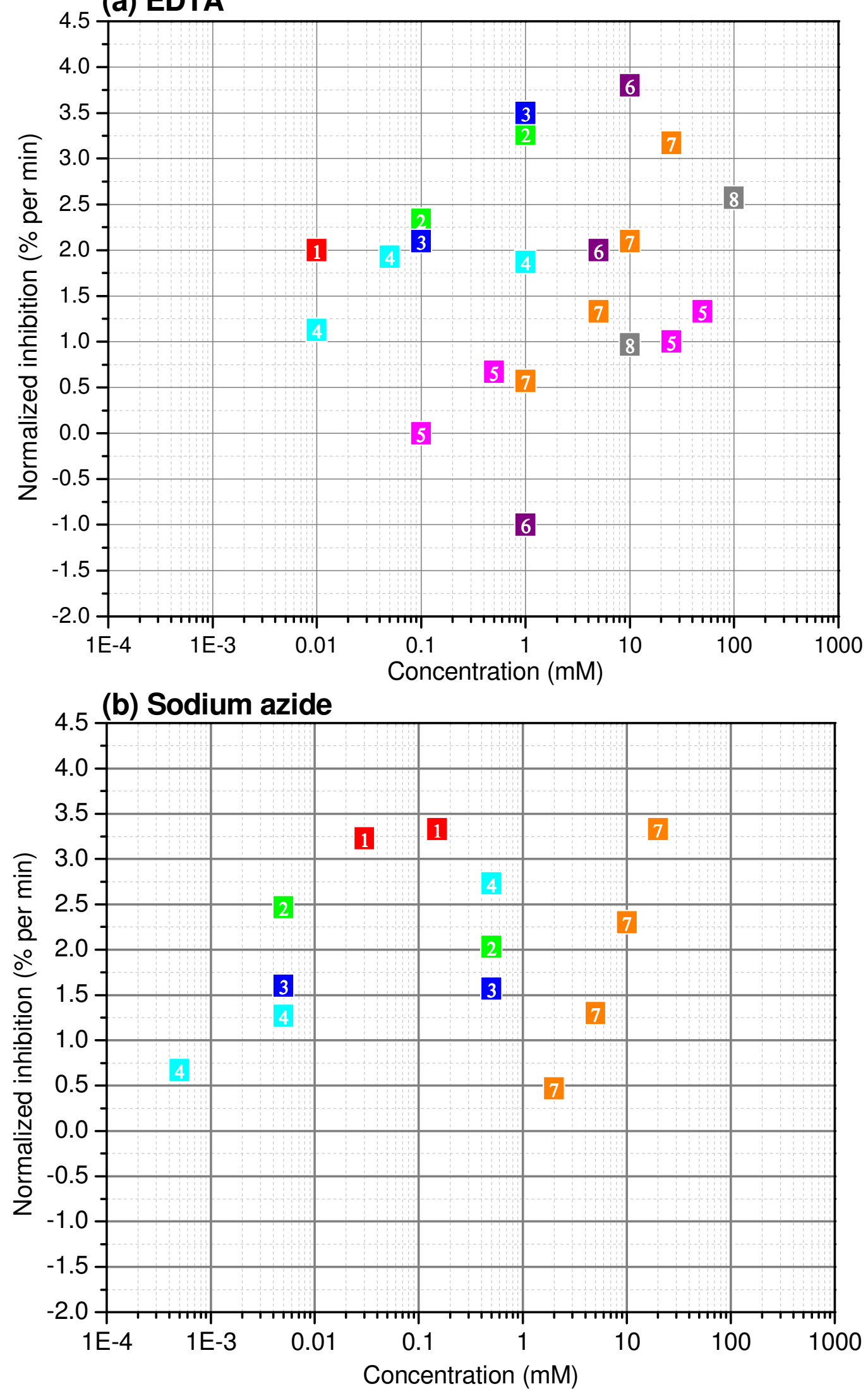

Figure 6 


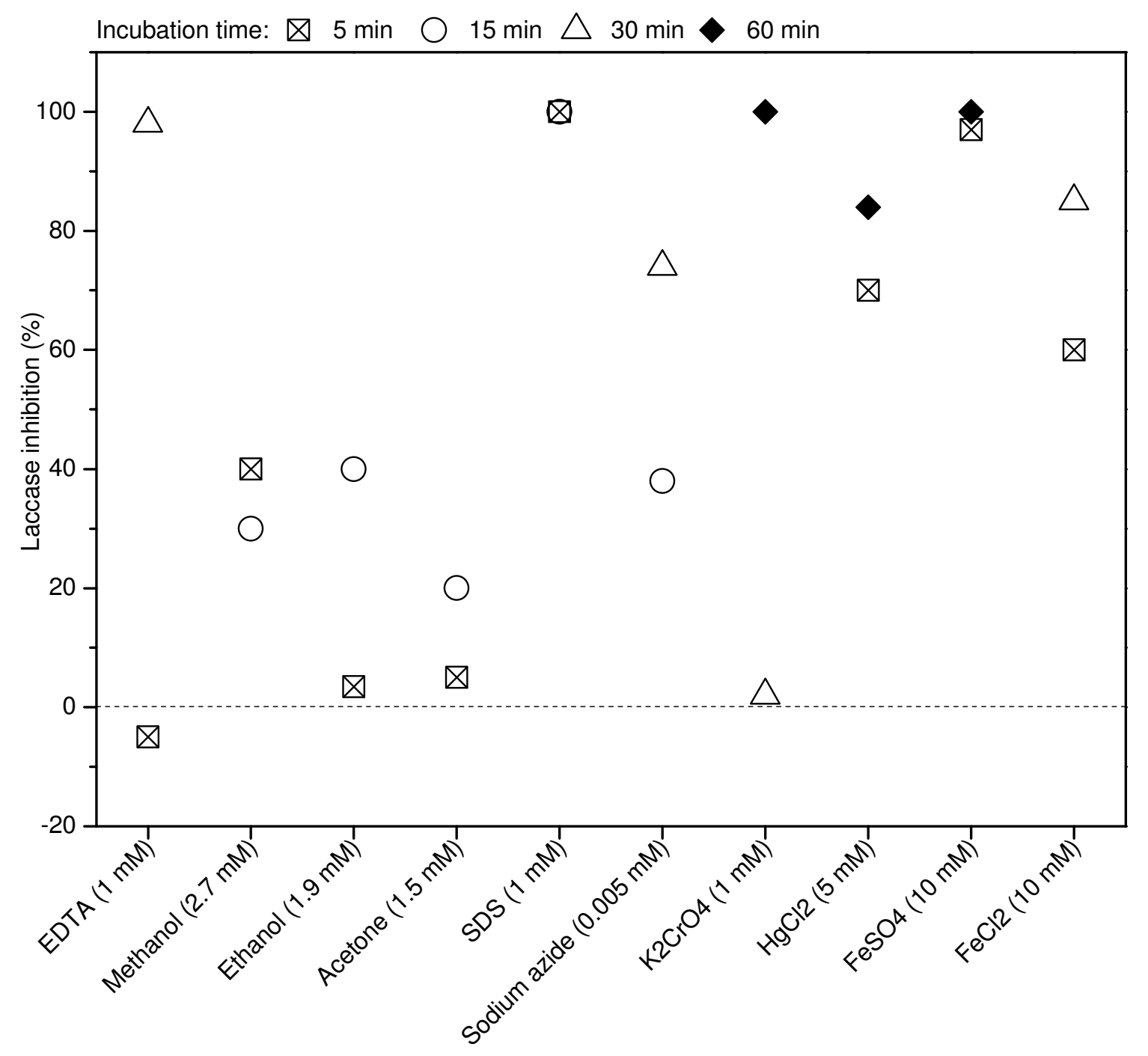

Figure 7 


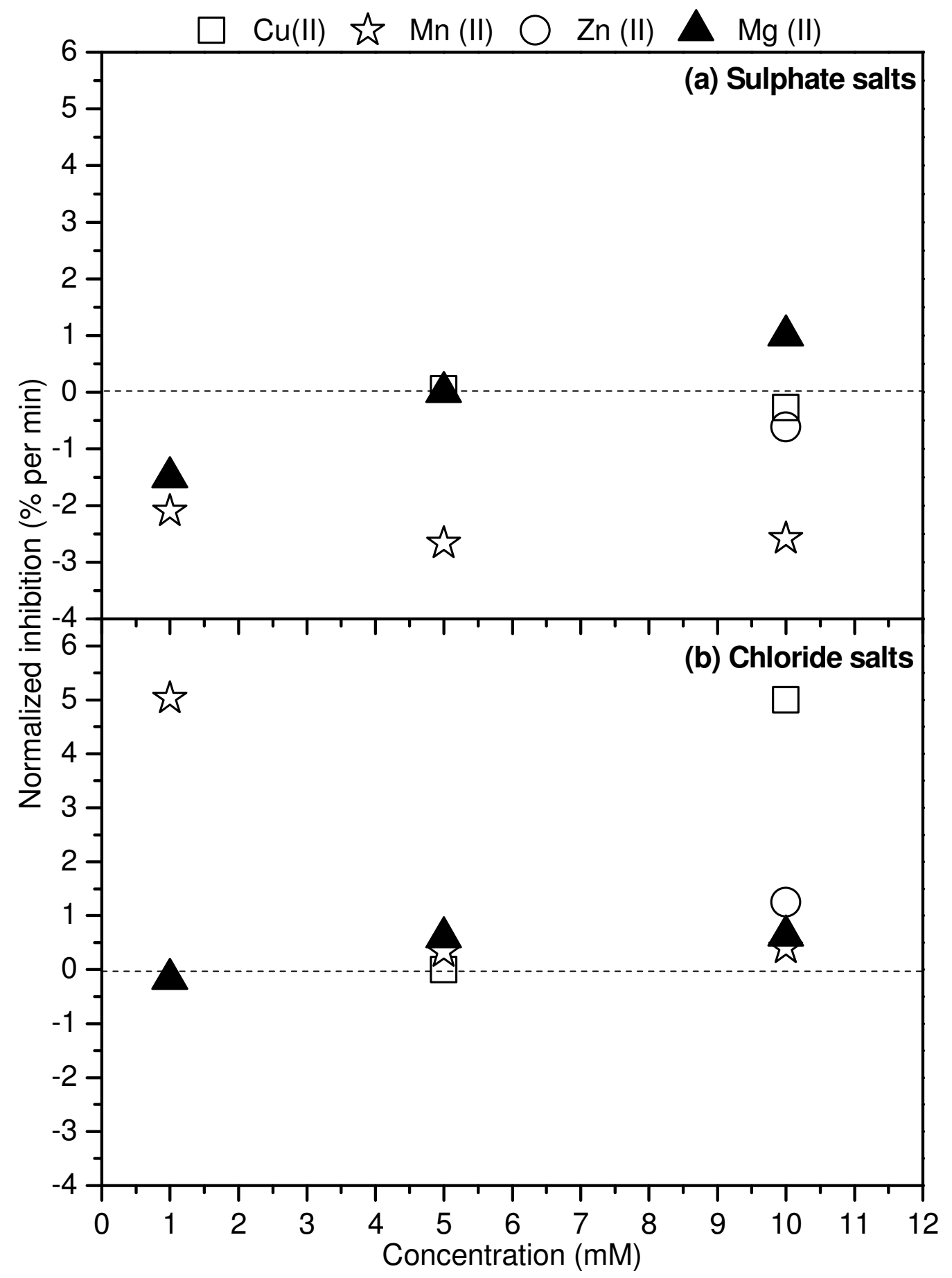

Figure 8 
Bisphenol A

Triclosan $\bigotimes 17 \beta$-estradiol

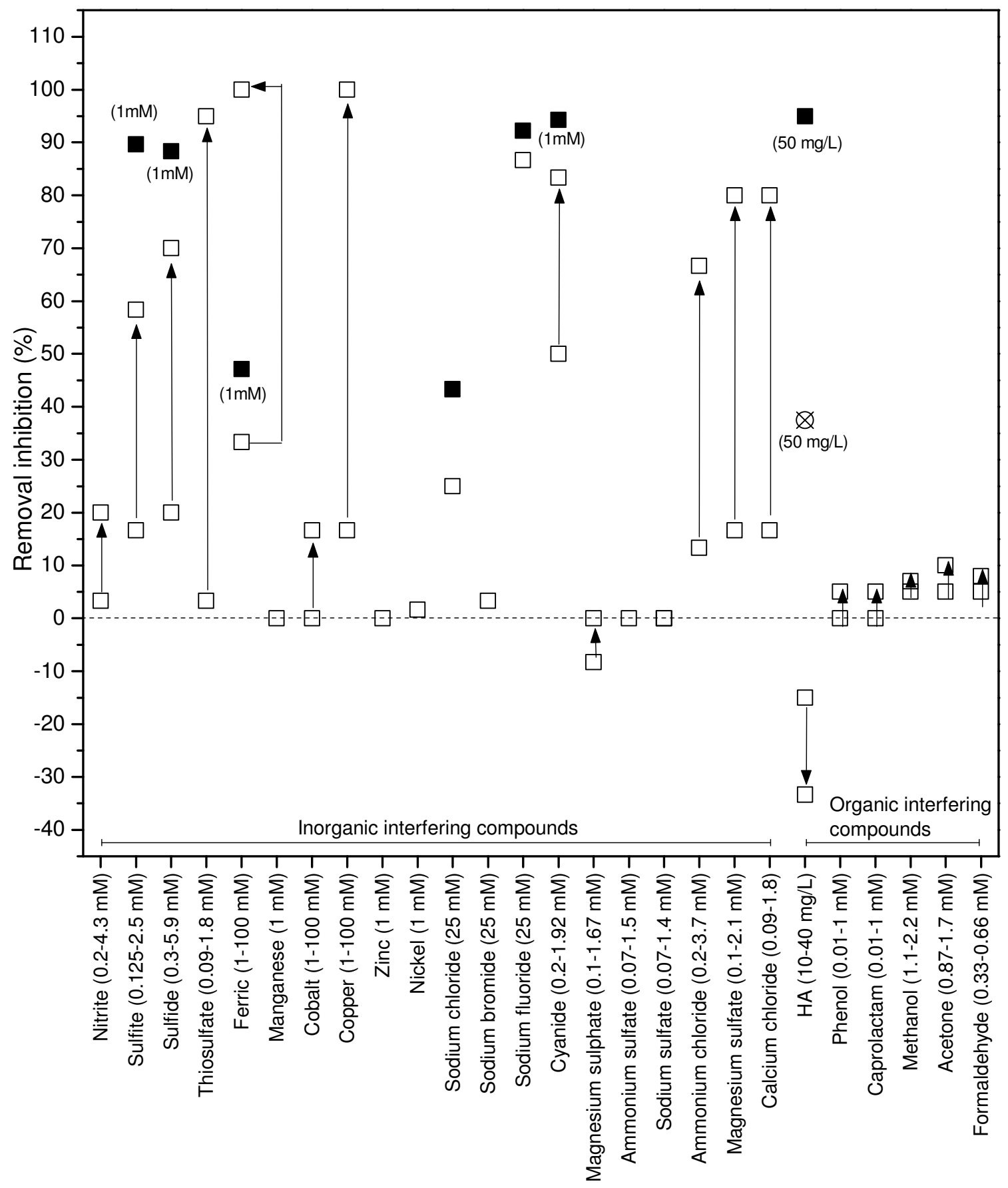

Figure 9 
(Supplementary Data)

Impact of wastewater derived dissolved interfering compounds on growth, enzymatic activity and trace organic contaminant removal of white rot fungi - a critical review

\section{(Journal of Environmental Management)}

Muhammad B. Asif ${ }^{\text {a }}$, Faisal I. Hai ${ }^{\text {a* }}$, Jingwei Hou ${ }^{\text {b }}$, William E. Price ${ }^{c}$, Long D. Nghiem ${ }^{\text {a }}$

${ }^{a}$ Strategic Water Infrastructure Lab, School of Civil, Mining and Environmental Engineering, University of Wollongong (UOW), Wollongong, NSW 2522, Australia.

${ }^{\mathrm{b}}$ UNESCO Centre for Membrane Science and Technology, School of Chemical Engineering, University of New South Wales, Sydney, NSW 2052, Australia

c Strategic Water Infrastructure Lab, School of Chemistry, University of Wollongong (UOW), Wollongong, NSW 2522, Australia.

*Corresponding author: Faisal I. Hai (E-mail: faisal@uow.edu.au; Ph: +61 2 42213054) 
Table S1: TrOC removal (\%) by whole-cell WRF, crude and purified laccase. Data of WRF species which predominantly secrete laccase is included. Removal presented as median \pm standard deviation. Numbers within parenthesis indicate number of data point $\left(\mathrm{n}_{\text {whole-cell }} \mathrm{wRF}_{\mathrm{r}}+\mathrm{n}_{\text {crude laccase }}+\mathrm{n}_{\text {purified laccase }}\right)$.

\begin{tabular}{|c|c|c|c|}
\hline \multirow{2}{*}{$\begin{array}{c}\text { TrOCs }\left(\mathrm{n}_{\text {Whole-cell WRF }}+\mathrm{n}_{\text {crude }}\right. \\
\quad \text { laccase } \\
\left.+\mathrm{n}_{\text {purified laccase }}\right)\end{array}$} & \multicolumn{3}{|c|}{ Removal efficiency $(\%)$} \\
\hline & Whole-cell WRF $^{1}$ & Crude laccase $^{2}$ & Purified laccase $^{3}$ \\
\hline \multicolumn{4}{|c|}{ Compounds containing strong electron donating group } \\
\hline Bisphenol $\mathrm{A} *(2+5+6)$ & $85 \pm 20$ & $88 \pm 14$ & $82 \pm 24$ \\
\hline Estrone* $(1+3+8)$ & 80 & $98 \pm 11$ & $67 \pm 17$ \\
\hline $17 \alpha$-Ethynylestradiol* $(1+4+8)$ & $>60$ & $98.5 \pm 9$ & $87.5 \pm 9$ \\
\hline $17 \beta$-estradiol -17 acetate $*(0+3+3)$ & $>80$ & $89 \pm 12$ & $95 \pm 3$ \\
\hline $17 \beta$-estradiol* $(1+4+8)$ & $>65$ & $98.5 \pm 7$ & $91 \pm 13$ \\
\hline 4-tert-octylphenol* $(1+3+3)$ & $>90$ & $90 \pm 3$ & $95 \pm 3$ \\
\hline \multicolumn{4}{|c|}{ Compounds containing both electron withdrawing and donating group } \\
\hline Sulfamethoxazole $(3+1+2)$ & $99 \pm 2.3$ & $<5$ & $48 \pm 55$ \\
\hline Ibuprofen $(6+3+3)$ & $99 \pm 0.5$ & $3 \pm 7$ & $40 \pm 24$ \\
\hline Salicylic acid* $(2+3+3)$ & $37 \pm 47$ & $2 \pm 12$ & $40 \pm 23$ \\
\hline Triclosan* $(1+4+4)$ & 80 & $69 \pm 14$ & $94 \pm 4$ \\
\hline Ketoprofen $(6+4+3)$ & $99 \pm 1$ & $7 \pm 18$ & $22 \pm 14$ \\
\hline Diclofenac $(6+5+7)$ & $99 \pm 4$ & $52 \pm 37$ & $41 \pm 26$ \\
\hline Clofibric acid $(4+3+3)$ & $80 \pm 40$ & $7 \pm 3$ & $10 \pm 7$ \\
\hline Pentachlorophenol* $(1+3+3)$ & 65 & $22 \pm 8$ & $50 \pm 29$ \\
\hline Naproxen $(6+5+6)$ & $99 \pm 1.8$ & $16 \pm 42$ & $2 \pm 9$ \\
\hline Fenoprop $(2+3+3)$ & $50 \pm 68$ & $10 \pm 8$ & $10 \pm 8$ \\
\hline Gemfibrozil $(2+3+3)$ & $86 \pm 20$ & $16 \pm 15$ & $4 \pm 5$ \\
\hline Atrazine $(1+3+5)$ & $<20$ & $5 \pm 7$ & $8 \pm 34$ \\
\hline \multicolumn{4}{|c|}{ Compounds containing strong electron withdrawing group } \\
\hline Carbamazepine $(7+4+6)$ & $60 \pm 50$ & $4 \pm 1.8$ & $8.5 \pm 32$ \\
\hline Primidone $(1+3+3)$ & $<10$ & $6 \pm 3.5$ & $3 \pm 1.9$ \\
\hline Metronidazole $(2+2+3)$ & $52 \pm 68$ & $13.5 \pm 2$ & $2 \pm 4$ \\
\hline
\end{tabular}

"**”: represents the compounds with phenolic moieties; “-“: indicates that data is not available.

${ }^{1}$ Data source: Cruz-Morató et al. (2013); Golan-Rozen et al. (2015); Hata et al. (2010); Hirano et al. (2000);

Kang et al. (2008); Marco-Urrea et al. (2006); Marco-Urrea et al. (2008); Marco-Urrea et al. (2010a); MarcoUrrea et al. (2010b); Nguyen et al. (2013); Popa et al. (2015); Rodarte-Morales et al. (2011); Suzuki et al. (2003); Tran et al. (2010); and Yang et al. (2013).

${ }^{2}$ Data source: Ashe et al. (2016); Tran et al. (2010); Kim and Nicell (2006); Nguyen et al. (2013); Nguyen et al. (2014a); Spina et al. (2015); Suda et al. (2012); Suzuki et al. (2003); Tran et al. (2010); and Yang et al. (2013).

${ }^{3}$ Data source: Lloret et al. (2010); Lloret et al. (2013); Margot et al. (2013); Nguyen et al. (2014a); Nguyen et al. (2014b); Nguyen et al. (2014c); Nguyen et al. (2015); Spina et al. (2015); and Tran et al. (2010). 
Table S2: Characteristics of real wastewater. Data source: Auriol et al. (2007); Auriol et al. (2008); Carletti et al. (2008); Cruz-Morató et al. (2013); Cruz-Morató et al. (2014); Mir-Tutusaus et al. (2016); and Spina et al. (2015).

\begin{tabular}{lll}
\hline Parameters & Unit & Values \\
\hline $\mathrm{pH}$ & $\mathrm{mS} / \mathrm{cm}$ & $6.7-8.64$ \\
Conductivity & $\mathrm{mg} / \mathrm{L}$ & $1.2-4.7$ \\
COD & $\mathrm{mg} / \mathrm{L}$ & $39-614$ \\
TOC & $\mathrm{cfu} / \mathrm{ml}$ & 19 \\
Heterotrophic plate count & $\mathrm{mg} / \mathrm{L}$ & 26.5 \\
Total nitrogen & $\mathrm{mg} / \mathrm{L}$ & $0.2-2.7$ \\
Total phosphorus & $\mathrm{mg} / \mathrm{L}$ & $85-350$ \\
Total suspended solids & $\mathrm{mg} / \mathrm{L}$ & $14-42$ \\
Ammonium & $\mu \mathrm{g} / \mathrm{L}$ & $9.8-60$ \\
Copper & $\mu \mathrm{g} / \mathrm{L}$ & $0.4-27$ \\
Cadmium & $\mu \mathrm{g} / \mathrm{L}$ & $300-2400$ \\
Ferric & $\mathrm{mg} / \mathrm{L}$ & 170 \\
Sodium & $\mathrm{mg} / \mathrm{L}$ & 32.5 \\
Calcium & $\mu \mathrm{g} / \mathrm{L}$ & $2.7-8.8$ \\
Arsenic & $\mu \mathrm{g} / \mathrm{L}$ & $2-10.5$ \\
Lead & $\mu \mathrm{g} / \mathrm{L}$ & $3-61$ \\
Nickel & $\mu \mathrm{g} / \mathrm{L}$ & $8-59$ \\
Chromium & $\mu \mathrm{g} / \mathrm{L}$ & $225-2500$ \\
Zinc & $\mu \mathrm{g} / \mathrm{L}$ & $400-2600-$ \\
Aluminum & $\mu \mathrm{g} / \mathrm{L}$ & $0.7-3.8$ \\
Mercury & $\mathrm{mg} / \mathrm{L}$ & 0.4 \\
Nitrite & $\mathrm{mg} \mathrm{N} / \mathrm{L}$ & $170-250$ \\
Nitrate & $\mathrm{mg} / \mathrm{L}(\mathrm{mM})$ & $240-1500(7.13-40)$ \\
Chloride & $\mathrm{mM}$ & $0.6-1.3$ \\
Sulfate & $\mathrm{mM}$ & 0.05 \\
Fluoride & $\mathrm{mM}$ & 0.002 \\
Cyanide & & \\
\hline
\end{tabular}


Table S3. Inhibition (\%) of purified laccases from different WRF species in the presence of inorganic interfering compounds

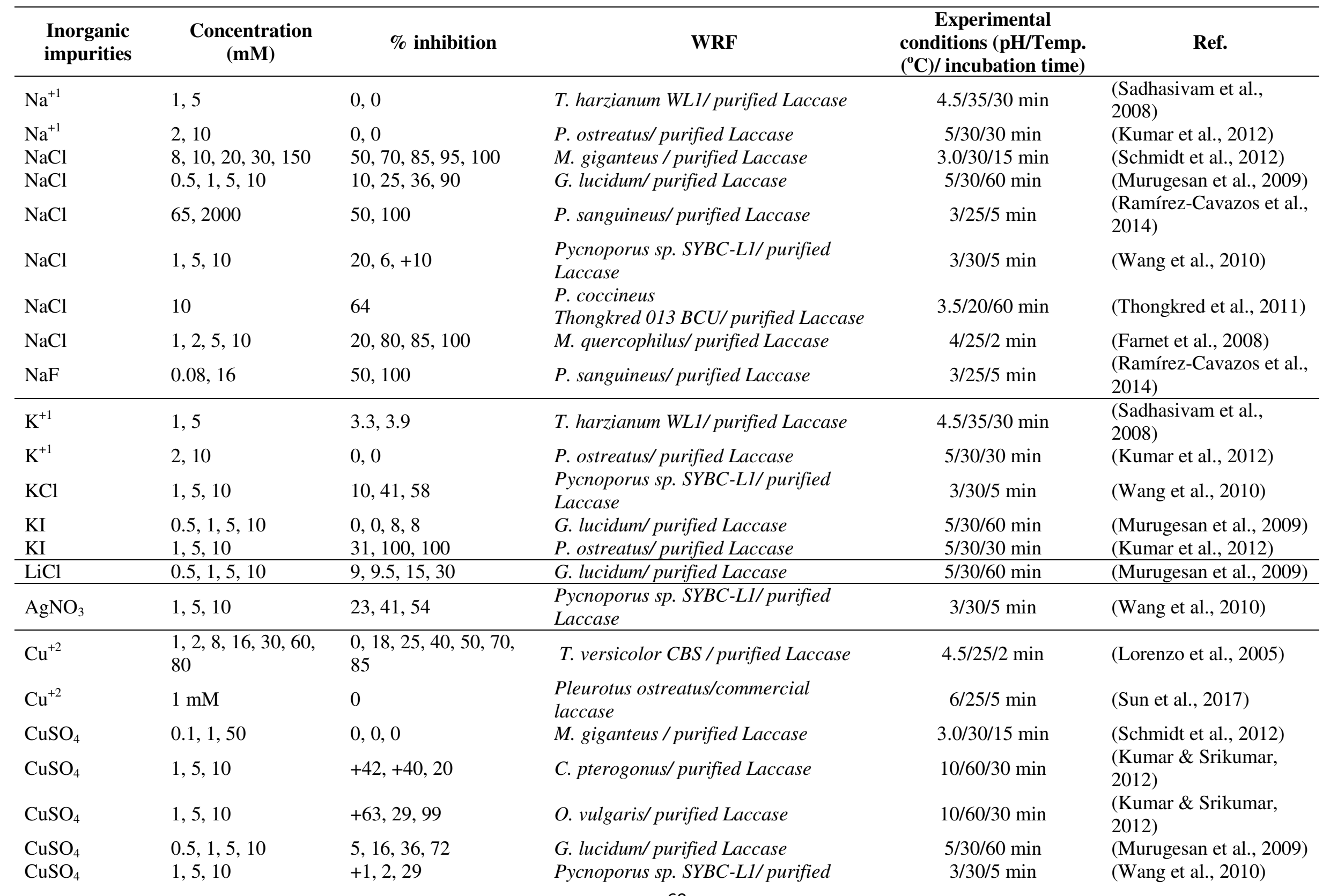




\begin{tabular}{|c|c|c|c|c|c|}
\hline $\mathrm{CuSO}_{4}$ & 10 & 2 & $\begin{array}{l}\text { Laccase } \\
\text { P. coccineus } \\
\text { Thongkred } 013 \text { BCU/ purified Laccase }\end{array}$ & $3.5 / 20 / 60 \mathrm{~min}$ & (Thongkred et al., 2011) \\
\hline $\begin{array}{l}\mathrm{CuSO}_{4} \\
\mathrm{CuCl}_{2}\end{array}$ & $\begin{array}{l}5 \\
5,10,20,30 \\
\end{array}$ & $\begin{array}{l}+10 \\
0,+10,40,60\end{array}$ & $\begin{array}{l}\text { P. ostreatus/ purified Laccase } \\
\text { M. quercophilus/ purified Laccase }\end{array}$ & $\begin{array}{l}5 / 30 / 30 \min \\
4 / 25 / 2 \min \end{array}$ & $\begin{array}{l}\text { (Kumar et al., 2012) } \\
\text { (Farnet et al., 2008) }\end{array}$ \\
\hline $\mathrm{Mn}^{+2}$ & $\begin{array}{l}1,2,8,16,30,60, \\
80\end{array}$ & No impact & T. versicolor CBS / purified Laccase & $4.5 / 25 / 2 \mathrm{~min}$ & (Lorenzo et al., 2005) \\
\hline $\mathrm{Mn}^{+2}$ & $0,1 \mathrm{mM}$ & 0 & $\begin{array}{l}\text { Pleurotus ostreatus/commercial } \\
\text { laccase }\end{array}$ & $6 / 25 / 5 \min$ & (Sun et al., 2017) \\
\hline $\mathrm{Mn}^{+2}$ & 1,5 & $0.8,1.2$ & T. harzianum WL1/ purified Laccase & $4.5 / 35 / 30 \mathrm{~min}$ & $\begin{array}{l}\text { (Sadhasivam et al., } \\
\text { 2008) }\end{array}$ \\
\hline $\begin{array}{l}\mathrm{Mn}^{+2} \\
\mathrm{MnSO}_{4}\end{array}$ & $\begin{array}{l}2,10 \\
0.1,1,50\end{array}$ & $\begin{array}{l}+32,+20 \\
0,0,+2\end{array}$ & $\begin{array}{l}\text { P. ostreatus/ purified Laccase } \\
\text { M. giganteus / purified Laccase }\end{array}$ & $\begin{array}{l}5 / 30 / 30 \mathrm{~min} \\
3.0 / 30 / 15 \mathrm{~min}\end{array}$ & $\begin{array}{l}\text { (Kumar et al., 2012) } \\
\text { (Schmidt et al., 2012) }\end{array}$ \\
\hline $\mathrm{MnSO}_{4}$ & $1,5,10$ & $+43,+68,+8$ & C. pterogonus/ purified Laccase & $10 / 60 / 30 \mathrm{~min}$ & $\begin{array}{l}\text { (Kumar \& Srikumar, } \\
\text { 2012) }\end{array}$ \\
\hline $\mathrm{MnSO}_{4}$ & $1,5,10$ & $+180,+302,+240$ & O. vulgaris/ purified Laccase & $10 / 60 / 30 \mathrm{~min}$ & $\begin{array}{l}\text { (Kumar \& Srikumar, } \\
\text { 2012) }\end{array}$ \\
\hline $\mathrm{MnSO}_{4}$ & $5,10,15,20$ & $10,+10,0,+20$ & M. quercophilus/ purified Laccase & $4 / 25 / 2 \min$ & (Farnet et al., 2008) \\
\hline $\mathrm{MnSO}_{4}$ & $1,5,10$ & $6,12,14$ & $\begin{array}{l}\text { Pycnoporus sp. SYBC-L1/ purified } \\
\text { Laccase }\end{array}$ & $3 / 30 / 5 \min$ & (Wang et al., 2010) \\
\hline $\mathrm{MnSO}_{4}$ & 10 & 5 & $\begin{array}{l}\text { P. coccineus } \\
\text { Thongkred } 013 \text { BCU/ purified Laccase }\end{array}$ & $3.5 / 20 / 60 \mathrm{~min}$ & (Thongkred et al., 2011) \\
\hline $\mathrm{MnCl}_{2}$ & $0.5,1,5,10$ & $6,4.5,19.5,24$ & G. lucidum/ purified Laccase & $5 / 30 / 60 \mathrm{~min}$ & (Murugesan et al., 2009) \\
\hline $\mathrm{MnCl}_{2}$ & $6.25,15.5,25,50$ & $13,46,56,70$ & A. pullulans NAC8/ purified Laccase & $5 / 25 / 15 \min$ & $\begin{array}{l}\text { (Ademakinwa \& } \\
\text { Agboola, 2016) }\end{array}$ \\
\hline $\mathrm{MnCl}_{2}$ & $1,2,5$ & $20,60,100$ & M. quercophilus/purified Laccase & $4 / 25 / 2 \min$ & (Farnet et al., 2008) \\
\hline $\mathrm{Zn}^{+2}$ & $\begin{array}{l}1,2,8,16,30,60 \\
80\end{array}$ & No impact & T. versicolor CBS / purified Laccase & $4.5 / 25 / 2 \mathrm{~min}$ & (Lorenzo et al., 2005) \\
\hline $\begin{array}{l}\mathrm{Zn}^{+2} \\
\mathrm{Zn}^{+2}\end{array}$ & $\begin{array}{l}1,5 \\
2,10\end{array}$ & $\begin{array}{l}7.6,11.4 \\
13,37\end{array}$ & $\begin{array}{l}\text { M. giganteus / purified Laccase } \\
\text { P. ostreatus/ purified Laccase }\end{array}$ & $\begin{array}{l}3.0 / 30 / 15 \min \\
5 / 30 / 30 \mathrm{~min}\end{array}$ & $\begin{array}{l}\text { (Schmidt et al., 2012) } \\
\text { (Kumar et al., 2012) }\end{array}$ \\
\hline $\mathrm{ZnSO}_{4}$ & $0.5,1,5,10$ & $+6,+18,+23,+37$ & G. lucidum/ purified Laccase & $5 / 30 / 60 \mathrm{~min}$ & (Murugesan et al., 2009) \\
\hline $\mathrm{ZnSO}_{4}$ & $1,5,10$ & $1,2,13$ & $\begin{array}{l}\text { Pycnoporus sp. SYBC-L1/ purified } \\
\text { Laccase }\end{array}$ & $3 / 30 / 5 \mathrm{~min}$ & (Wang et al., 2010) \\
\hline $\mathrm{ZnCl}_{2}$ & $10 \mu \mathrm{M}$ & 57 & $\begin{array}{l}\text { C. polyzona }(\text { MUCL 38443)/ purified } \\
\text { Laccase }\end{array}$ & $3.0 / 20 / 30 \mathrm{~min}$ & (Cabana et al., 2007) \\
\hline $\mathrm{ZnCl}_{2}$ & 10 & 75 & $\begin{array}{l}\text { P. coccineus } \\
\text { Thongkred } 013 \text { BCU/ purified Laccase }\end{array}$ & $3.5 / 20 / 60 \mathrm{~min}$ & (Thongkred et al., 2011) \\
\hline $\mathrm{Co}^{+2}$ & 1,5 & $1.8,3.6$ & T. harzianum WL1/ purified Laccase & $4.5 / 35 / 30 \mathrm{~min}$ & $\begin{array}{l}\text { (Sadhasivam et al., } \\
\text { 2008) }\end{array}$ \\
\hline $\mathrm{Co}^{+2}$ & 2,10 & 0,19 & P. ostreatus/ purified Laccase & $5 / 30 / 30 \mathrm{~min}$ & (Kumar et al., 2012) \\
\hline
\end{tabular}




\begin{tabular}{|c|c|c|c|c|c|}
\hline $\mathrm{CoCl}_{2}$ & $10 \mu \mathrm{M}$ & 44 & $\begin{array}{l}\text { C. polyzona (MUCL 38443)/ purified } \\
\text { Laccase }\end{array}$ & $3.0 / 20 / 30 \mathrm{~min}$ & (Cabana et al., 2009) \\
\hline $\mathrm{CoCl}_{2}$ & $0.5,1,5,10$ & $+6,+4,7,17$ & G. lucidum/ purified Laccase & $5 / 30 / 60 \mathrm{~min}$ & (Murugesan et al., 2009) \\
\hline $\mathrm{CoCl}_{2}$ & $6.25,15.5,25,50$ & $61,62,71,87$ & A. pullulans NAC8/ purified Laccase & $5 / 25 / 15 \min$ & $\begin{array}{l}\text { (Ademakinwa \& } \\
\text { Agboola, 2016) }\end{array}$ \\
\hline $\mathrm{Mg}^{+2}$ & 1,5 & $1.4,2.8$ & T. harzianum WL1/ purified Laccase & $4.5 / 35 / 30 \mathrm{~min}$ & $\begin{array}{l}\text { (Sadhasivam et al., } \\
\text { 2008) }\end{array}$ \\
\hline $\mathrm{Mg}^{+2}$ & 2,10 & 13,41 & P. ostreatus/ purified Laccase & $5 / 30 / 30 \mathrm{~min}$ & (Kumar et al., 2012) \\
\hline $\mathrm{MgCl}_{2}$ & $1,5,10$ & $+2,+7,2$ & C. pterogonus/ purified Laccase & $10 / 60 / 30 \mathrm{~min}$ & $\begin{array}{l}\text { (Kumar \& Srikumar, } \\
\text { 2012) }\end{array}$ \\
\hline $\mathrm{MgCl}_{2}$ & $1,5,10$ & $+5,12,19$ & O. vulgaris/ purified Laccase & $10 / 60 / 30 \mathrm{~min}$ & $\begin{array}{l}\text { (Kumar \& Srikumar, } \\
\text { 2012) }\end{array}$ \\
\hline $\mathrm{MgCl}_{2}$ & $6.25,15.5,25,50$ & $+7,13,36,45$ & A. pullulans NAC8/ purified Laccase & $5 / 25 / 15 \min$ & $\begin{array}{l}\text { (Ademakinwa \& } \\
\text { Agboola, 2016) }\end{array}$ \\
\hline $\mathrm{Ba}^{+2}$ & 1,5 & $0,0.6$ & T. harzianum WL1/ purified Laccase & $4.5 / 35 / 30 \mathrm{~min}$ & $\begin{array}{l}\text { (Sadhasivam et al., } \\
\text { 2008) }\end{array}$ \\
\hline $\mathrm{Ca}^{+2}$ & $0,1 \mathrm{mM}$ & 0 & $\begin{array}{l}\text { Pleurotus ostreatus/commercial } \\
\text { laccase }\end{array}$ & $6 / 25 / 5 \mathrm{~min}$ & (Sun et al., 2017) \\
\hline $\mathrm{Ca}\left(\mathrm{NO}_{3}\right)_{2}$ & $0.5,1,5,10$ & $+4,+4,+6,1$ & G. lucidum/ purified Laccase & $5 / 30 / 60 \mathrm{~min}$ & (Murugesan et al., 2009) \\
\hline $\mathrm{CaCl}_{2}$ & $10 \mu \mathrm{M}$ & 50 & $\begin{array}{l}\text { C. polyzona (MUCL } 38443) / \text { purified } \\
\text { Laccase }\end{array}$ & $3.0 / 20 / 30 \mathrm{~min}$ & (Cabana et al., 2009) \\
\hline $\mathrm{CaCl}_{2}$ & $10 \mu \mathrm{M}$ & 48 & $\begin{array}{l}\text { C. polyzona (MUCL 38443)/ purified } \\
\text { Laccase }\end{array}$ & $3.0 / 20 / 30 \mathrm{~min}$ & (Cabana et al., 2007) \\
\hline $\mathrm{CaCl}_{2}$ & $1,5,10$ & $3,+3,2$ & M. giganteus / purified Laccase & $3.0 / 30 / 15 \mathrm{~min}$ & (Schmidt et al., 2012) \\
\hline $\mathrm{CaCl}_{2}$ & $1,5,10$ & $+2,17,11$ & O. vulgaris/ purified Laccase & $10 / 60 / 30 \mathrm{~min}$ & $\begin{array}{l}\text { (Kumar \& Srikumar, } \\
\text { 2012) }\end{array}$ \\
\hline $\mathrm{CaCl}_{2}$ & $6.25,15.5,25,50$ & $23,35,70,78$ & A. pullulans NAC8/ purified Laccase & $5 / 25 / 15 \min$ & $\begin{array}{l}\text { (Ademakinwa \& } \\
\text { Agboola, 2016) }\end{array}$ \\
\hline $\mathrm{CaCl}_{2}$ & $1,5,10$ & $20,42,80$ & $\begin{array}{l}\text { Pycnoporus sp. SYBC-L1/ purified } \\
\text { Laccase }\end{array}$ & $3 / 30 / 5 \min$ & (Wang et al., 2010) \\
\hline
\end{tabular}




\begin{tabular}{|c|c|c|c|c|c|}
\hline $\mathrm{CaCl}_{2}$ & $5,10,20,30$ & $20,30,60,80$ & M. quercophilus/ purified Laccase & $4 / 25 / 2 \min$ & (Farnet et al., 2008) \\
\hline $\mathrm{Sn}^{+2}$ & 1,5 & $1.1,9.7$ & T. harzianum WL1/ purified Laccase & $4.5 / 35 / 30 \mathrm{~min}$ & $\begin{array}{l}\text { (Sadhasivam et al., } \\
\text { 2008) }\end{array}$ \\
\hline $\mathrm{Cd}^{+2}$ & $2,8,16,30,60$ & $10,18,40,70,100$ & T. versicolor CBS / purified Laccase & $4.5 / 25 / 2 \mathrm{~min}$ & (Lorenzo et al., 2005) \\
\hline $\mathrm{Cd}^{+2}$ & 2,10 & 0,10 & P. ostreatus/ purified Laccase & $5 / 30 / 30 \mathrm{~min}$ & (Kumar et al., 2012) \\
\hline $\mathrm{CdCl}_{2}$ & $0.5,1,5,10$ & $0,7,18,20$ & G. lucidum/ purified Laccase & $5 / 30 / 60 \mathrm{~min}$ & (Murugesan et al., 2009) \\
\hline $\mathrm{NiCl}_{2}$ & $0.5,1,5,10$ & $4,2,13,19$ & G. lucidum/ purified Laccase & $5 / 30 / 60 \mathrm{~min}$ & (Murugesan et al., 2009) \\
\hline $\mathrm{NiCl}_{2}$ & $6.25,15.5,25,50$ & $40,54,76,87$ & A. pullulans NAC8/ purified Laccase & $5 / 25 / 15 \mathrm{~min}$ & $\begin{array}{l}\text { (Ademakinwa \& } \\
\text { Agboola, 2016) }\end{array}$ \\
\hline $\mathrm{Fe}^{+2}$ & 2,10 & 91,98 & P. ostreatus/ purified Laccase & $5 / 30 / 30 \mathrm{~min}$ & (Kumar et al., 2012) \\
\hline $\mathrm{Fe}^{+2}$ & $0,1 \mathrm{mM}$ & 50 & $\begin{array}{l}\text { Pleurotus ostreatus/commercial } \\
\text { laccase }\end{array}$ & $6 / 25 / 5 \min$ & (Sun et al., 2017) \\
\hline $\mathrm{Fe}^{+3}$ & 1,5 & $1.5,2.0$ & T. harzianum WL1/ purified Laccase & $4.5 / 35 / 30$ & $\begin{array}{l}\text { (Sadhasivam et al., } \\
\text { 2008) }\end{array}$ \\
\hline $\mathrm{FeSO}_{4}$ & $1,5,10$ & $90,100,100$ & $\begin{array}{l}\text { Pycnoporus sp. SYBC-L1/ purified } \\
\text { Laccase }\end{array}$ & $3 / 30 / 5 \min$ & (Wang et al., 2010) \\
\hline $\mathrm{FeSO}_{4}$ & 10 & 98 & $\begin{array}{l}\text { P. coccineus } \\
\text { Thongkred } 013 \text { BCU/ purified Laccase }\end{array}$ & $3.5 / 20 / 60 \mathrm{~min}$ & (Thongkred et al., 2011) \\
\hline $\mathrm{FeCl}_{2}$ & $1,5,10$ & $63,77,98$ & C. pterogonus/ purified Laccase & $10 / 60 / 30 \mathrm{~min}$ & $\begin{array}{l}\text { (Kumar \& Srikumar, } \\
\text { 2012) }\end{array}$ \\
\hline $\mathrm{FeCl}_{2}$ & $1,5,10$ & $85,99,78$ & O. vulgaris/ purified Laccase & $10 / 60 / 30 \mathrm{~min}$ & $\begin{array}{l}\text { (Kumar \& Srikumar, } \\
\text { 2012) }\end{array}$ \\
\hline $\mathrm{FeCl}_{2}$ & 10 & 60 & $\begin{array}{l}\text { P. coccineus } \\
\text { Thongkred } 013 \text { BCU/ purified Laccase }\end{array}$ & $3.5 / 20 / 60 \mathrm{~min}$ & (Thongkred et al., 2011) \\
\hline $\mathrm{FeCl}_{2}$ & $1,5,10$ & $60,100,100$ & $\begin{array}{l}\text { Pycnoporus sp. SYBC-L1/ purified } \\
\text { Laccase }\end{array}$ & $3 / 30 / 5 \mathrm{~min}$ & (Wang et al., 2010) \\
\hline $\mathrm{Hg}^{+2}$ & 1,5 & $17.2,25.4$ & T. harzianum WL1/ purified Laccase & $4.5 / 35 / 30$ & $\begin{array}{l}\text { (Sadhasivam et al., } \\
\text { 2008) }\end{array}$ \\
\hline $\mathrm{Hg}^{+2}$ & 2,10 & 100,100 & P. ostreatus/ purified Laccase & $5 / 30 / 30 \mathrm{~min}$ & (Kumar et al., 2012) \\
\hline $\mathrm{HgCl}_{2}$ & $0.5,1,5,10$ & $55,60,84,94$ & G. lucidum/ purified Laccase & $5 / 30 / 60 \mathrm{~min}$ & (Murugesan et al., 2009) \\
\hline $\mathrm{HgCl}_{2}$ & $5,10,15,20$ & $0,40,70,100$ & M. quercophilus/ purified Laccase & $4 / 25 / 2 \mathrm{~min}$ & (Farnet et al., 2008) \\
\hline $\mathrm{Pb}^{+2}$ & 2,10 & 89,97 & P. ostreatus/ purified Laccase & $5 / 30 / 30 \mathrm{~min}$ & (Kumar et al., 2012) \\
\hline $\mathrm{Al}^{+3}$ & $0,1 \mathrm{mM}$ & 60 & $\begin{array}{l}\text { Pleurotus ostreatus/commercial } \\
\text { laccase }\end{array}$ & $6 / 25 / 5 \mathrm{~min}$ & (Sun et al., 2017) \\
\hline $\mathrm{AlCl}_{3}$ & $1,5,10$ & $13,41,53$ & $\begin{array}{l}\text { Pycnoporus sp. SYBC-L1/ purified } \\
\text { Laccase }\end{array}$ & $3 / 30 / 5 \mathrm{~min}$ & (Wang et al., 2010) \\
\hline $\mathrm{Cr}^{+6}$ & 1,5 & $1.7,13.8$ & T. harzianum WL1/ purified Laccase & $4.5 / 35 / 30$ & $\begin{array}{l}\text { (Sadhasivam et al., } \\
\text { 2008) }\end{array}$ \\
\hline $\mathrm{K}_{2} \mathrm{CrO}_{4}$ & $0.5,1,5,10$ & $100,100,100,100$ & G. lucidum/ purified Laccase & $5 / 30 / 60 \mathrm{~min}$ & (Murugesan et al., 2009) \\
\hline $\mathrm{NaN}_{3}$ & $0.03,0.150$ & 97,100 & $\begin{array}{l}\text { C. polyzona (MUCL 38443)/ purified } \\
72\end{array}$ & $3.0 / 20 / 30 \mathrm{~min}$ & (Cabana et al., 2007) \\
\hline
\end{tabular}




\begin{tabular}{|c|c|c|c|c|c|}
\hline & & & Laccase & & \\
\hline $\mathrm{NaN}_{3}$ & $0.005,0.5$ & 74,61 & C. pterogonus/ purified Laccase & $10 / 60 / 30 \min$ & $\begin{array}{l}\text { (Kumar \& Srikumar, } \\
\text { 2012) }\end{array}$ \\
\hline $\mathrm{NaN}_{3}$ & $0.005,0.5$ & 48,47 & O. vulgaris/ purified Laccase & $10 / 60 / 30 \min$ & $\begin{array}{l}\text { (Kumar \& Srikumar, } \\
\text { 2012) }\end{array}$ \\
\hline $\mathrm{NaN}_{3}$ & $0.0005,0.005,0.5$ & $20,38,82$ & A. pullulans NAC8/ purified Laccase & $5 / 25 / 15 \min$ & $\begin{array}{l}\text { (Ademakinwa \& } \\
\text { Agboola, 2016) }\end{array}$ \\
\hline $\mathrm{NaN}_{3}$ & $6.2 \times 10^{-6}, 16$ & 50,100 & P. sanguineus/ purified Laccase & $3 / 25 / 5 \min$ & $\begin{array}{l}\text { (Ramírez-Cavazos et al., } \\
\text { 2014) }\end{array}$ \\
\hline $\mathrm{NaN}_{3}$ & $1,5,10$ & $100,100,100$ & $\begin{array}{l}\text { Pycnoporus sp. SYBC-L1/purified } \\
\text { Laccase }\end{array}$ & $3 / 30 / 5 \min$ & (Wang et al., 2010) \\
\hline NaN3 & $2,5,10,20$ & $14,39,69,100$ & T. harzianum WL1/ purified Laccase & $4.5 / 35 / 30$ & $\begin{array}{l}\text { (Sadhasivam et al., } \\
\text { 2008) }\end{array}$ \\
\hline $\mathrm{NaN}_{3}$ & $0.01 \%$ & 100 & C. albidus/purified laccase & $2.5 / 30 / 5 \mathrm{~min}$ & (Singhal et al., 2012) \\
\hline
\end{tabular}




\section{References:}

Ademakinwa, A.N., Agboola, F.K. 2016. Biochemical characterization and kinetic studies on a purified yellow laccase from newly isolated Aureobasidium pullulans NAC8 obtained from soil containing decayed plant matter. J. Genet. Eng. Biotechnol., 14(1), 143-151.

Ashe, B., Nguyen, L.N., Hai, F.I., Lee, D.-J., van de Merwe, J.P., Leusch, F.D., Price, W.E., Nghiem, L.D. 2016. Impacts of redox-mediator type on trace organic contaminants degradation by laccase: Degradation efficiency, laccase stability and effluent toxicity. International Biodeterioration \& Biodegradation, 113, 169-176.

Auriol, M., Filali-Meknassi, Y., Adams, C.D., Tyagi, R.D., Noguerol, T.-N., Pina, B. 2008. Removal of estrogenic activity of natural and synthetic hormones from a municipal wastewater: efficiency of horseradish peroxidase and laccase from Trametes versicolor. Chemosphere, 70(3), 445-452.

Auriol, M., Filali-Meknassi, Y., Tyagi, R.D., Adams, C.D. 2007. Laccase-catalyzed conversion of natural and synthetic hormones from a municipal wastewater. Water Research, 41(15), 3281-3288.

Cabana, H., Alexandre, C., Agathos, S.N., Jones, J.P. 2009. Immobilization of laccase from the white rot fungus Coriolopsis polyzona and use of the immobilized biocatalyst for the continuous elimination of endocrine disrupting chemicals. Bioresource technology, 100(14), 3447-3458.

Cabana, H., Jones, J.P., Agathos, S.N. 2007. Preparation and characterization of cross-linked laccase aggregates and their application to the elimination of endocrine disrupting chemicals. Journal of Biotechnology, 132(1), 23-31.

Carletti, G., Fatone, F., Bolzonella, D., Cecchi, F. 2008. Occurrence and fate of heavy metals in large wastewater treatment plants treating municipal and industrial wastewaters. Wat. Sci. Tech., 57(9), 1329-1336.

Cruz-Morató, C., Ferrando-Climent, L., Rodriguez-Mozaz, S., Barceló, D., Marco-Urrea, E., Vicent, T., Sarrà, M. 2013. Degradation of pharmaceuticals in non-sterile urban wastewater by Trametes versicolor in a fluidized bed bioreactor. Water Research, 47(14), 5200-5210.

Cruz-Morató, C., Lucas, D., Llorca, M., Rodriguez-Mozaz, S., Gorga, M., Petrovic, M., Barceló, D., Vicent, T., Sarrà, M., Marco-Urrea, E. 2014. Hospital wastewater treatment by fungal bioreactor: removal efficiency for pharmaceuticals and endocrine disruptor compounds. Science of The Total Environment, 493, 365-376.

Farnet, A., Gil, G., Ferre, E. 2008. Effects of pollutants on laccase activities of Marasmius quercophilus, a white-rot fungus isolated from a Mediterranean schlerophyllous litter. Chemosphere, 70(5), 895900.

Golan-Rozen, N., Seiwert, B., Riemenschneider, C., Reemtsma, T., Chefetz, B., Hadar, Y. 2015. Transformation Pathways of the Recalcitrant Pharmaceutical Compound Carbamazepine by the White-Rot Fungus Pleurotus ostreatus: Effects of Growth Conditions. Environmental Science \& Technology, 49(20), 12351-12362.

Hata, T., Kawai, S., Okamura, H., Nishida, T. 2010. Removal of diclofenac and mefenamic acid by the white rot fungus Phanerochaete sordida YK-624 and identification of their metabolites after fungal transformation. Biodegradation, 21(5), 681-689.

Hirano, T., Honda, Y., Watanabe, T., Kuwahara, M. 2000. Degradation of bisphenol A by the lignindegrading enzyme, manganese peroxidase, produced by the white-rot basidiomycete, Pleurotus ostreatus. Bioscience, Biotechnology, and Biochemistry, 64(9), 1958-1962.

Kang, A.-R., Choi, H.-T., Song, H.-G. 2008. Optimization of bisphenol A biodegradation by Trametes versicolor. Korean. J. Microbiol., 44(1), 37-42.

Kim, Y.J., Nicell, J.A. 2006. Laccase-catalysed oxidation of aqueous triclosan. Journal of Chemical Technology and Biotechnology, 81(8), 1344-1352.

Kumar, G.N., Srikumar, K. 2012. Characterization of xerophytic thermophilic laccase exhibiting metal ion-dependent dye decolorization potential. Applied biochemistry and biotechnology, 167(3), 662-676. 
Kumar, V.V., Sathyaselvabala, V., Premkumar, M., Vidyadevi, T., Sivanesan, S. 2012. Biochemical characterization of three phase partitioned laccase and its application in decolorization and degradation of synthetic dyes. J. Mol. Catal. B: Enzym., 74(1), 63-72.

Lloret, L., Eibes, G., Lú-Chau, T.A., Moreira, M.T., Feijoo, G., Lema, J.M. 2010. Laccase-catalyzed degradation of anti-inflammatories and estrogens. Biochemical Engineering Journal, 51(3), 124131.

Lloret, L., Eibes, G., Moreira, M.T., Feijoo, G., Lema, J.M. 2013. Removal of Estrogenic Compounds from Filtered Secondary Wastewater Effluent in a Continuous Enzymatic Membrane Reactor. Identification of Biotransformation Products. Environmental Science \& Technology, 47(9), 45364543.

Lorenzo, M., Moldes, D., Couto, S.R.g., Sanromán, M. 2005. Inhibition of laccase activity from Trametes versicolor by heavy metals and organic compounds. Chemosphere, $\mathbf{6 0}(8), 1124-1128$.

Marco-Urrea, E., Gabarrell, X., Sarrà, M., Caminal, G., Vicent, T., Reddy, C.A. 2006. Novel aerobic perchloroethylene degradation by the white-rot fungus Trametes versicolor. Environmental Science \& Technology, 40(24), 7796-7802.

Marco-Urrea, E., Parella, T., Gabarrell, X., Caminal, G., Vicent, T., Reddy, C.A. 2008. Mechanistics of trichloroethylene mineralization by the white-rot fungus Trametes versicolor. Chemosphere, 70(3), 404-410.

Marco-Urrea, E., Pérez-Trujillo, M., Blánquez, P., Vicent, T., Caminal, G. 2010a. Biodegradation of the analgesic naproxen by Trametes versicolor and identification of intermediates using HPLC-DADMS and NMR. Bioresource Technology, 101(7), 2159-2166.

Marco-Urrea, E., Pérez-Trujillo, M., Cruz-Morató, C., Caminal, G., Vicent, T. 2010b. Degradation of the drug sodium diclofenac by Trametes versicolor pellets and identification of some intermediates by NMR. Journal of Hazardous Materials, 176(1), 836-842.

Margot, J., Maillard, J., Rossi, L., Barry, D.A., Holliger, C. 2013. Influence of treatment conditions on the oxidation of micropollutants by Trametes versicolor laccase. New Biotechnol., 30(6), 803-813.

Mir-Tutusaus, J.A., Sarrà, M., Caminal, G. 2016. Continuous treatment of non-sterile hospital wastewater by Trametes versicolor: How to increase fungal viability by means of operational strategies and pretreatments. Journal of Hazardous Materials, 318, 561-570.

Murugesan, K., Kim, Y.-M., Jeon, J.-R., Chang, Y.-S. 2009. Effect of metal ions on reactive dye decolorization by laccase from Ganoderma lucidum. Journal of Hazardous Materials, 168(1), 523-529.

Nguyen, L.N., Hai, F.I., Kang, J., Leusch, F.D., Roddick, F., Magram, S.F., Price, W.E., Nghiem, L.D. 2014a. Enhancement of trace organic contaminant degradation by crude enzyme extract from Trametes versicolor culture: Effect of mediator type and concentration. J. Taiwan Inst. Chem. Eng., 45(4), 1855-1862.

Nguyen, L.N., Hai, F.I., Price, W.E., Kang, J., Leusch, F.D., Roddick, F., van de Merwe, J.P., Magram, S.F., Nghiem, L.D. 2015. Degradation of a broad spectrum of trace organic contaminants by an enzymatic membrane reactor: complementary role of membrane retention and enzymatic degradation. International Biodeterioration \& Biodegradation, 99, 115-122.

Nguyen, L.N., Hai, F.I., Price, W.E., Leusch, F.D., Roddick, F., Ngo, H.H., Guo, W., Magram, S.F., Nghiem, L.D. 2014b. The effects of mediator and granular activated carbon addition on degradation of trace organic contaminants by an enzymatic membrane reactor. Bioresource Technology, 167, 169-177.

Nguyen, L.N., Hai, F.I., Yang, S., Kang, J., Leusch, F.D., Roddick, F., Price, W.E., Nghiem, L.D. 2013. Removal of trace organic contaminants by an MBR comprising a mixed culture of bacteria and white-rot fungi. Bioresource Technology, 148, 234-241.

Nguyen, L.N., Hai, F.I., Yang, S., Kang, J., Leusch, F.D.L., Roddick, F., Price, W.E., Nghiem, L.D. 2014c. Removal of pharmaceuticals, steroid hormones, phytoestrogens, UV-filters, industrial chemicals and pesticides by Trametes versicolor: Role of biosorption and biodegradation. International Biodeterioration \& Biodegradation, 88, 169-175. 
Popa, C., Balaes, T., Favier, L., TĂNASE, C., Bahrim, G. 2015. White-rot fungus implications in clofibric acid biodegradation. Romanian Biotechnological Letters, 20(3), 10388.

Ramírez-Cavazos, L.I., Junghanns, C., Ornelas-Soto, N., Cárdenas-Chávez, D.L., Hernández-Luna, C., Demarche, P., Enaud, E., García-Morales, R., Agathos, S.N., Parra, R. 2014. Purification and characterization of two thermostable laccases from Pycnoporus sanguineus and potential role in degradation of endocrine disrupting chemicals. J. Mol. Catal. B: Enzym., 108, 32-42.

Rodarte-Morales, A., Feijoo, G., Moreira, M., Lema, J. 2011. Degradation of selected pharmaceutical and personal care products (PPCPs) by white-rot fungi. W. J. Microbio. Biotechnol., 27(8), 18391846.

Sadhasivam, S., Savitha, S., Swaminathan, K., Lin, F.-H. 2008. Production, purification and characterization of mid-redox potential laccase from a newly isolated Trichoderma harzianum WL1. Process Biochemistry, 43(7), 736-742.

Schmidt, G., Krings, U., Nimtz, M., Berger, R.G. 2012. A surfactant tolerant laccase of Meripilus giganteus. W. J. Microbio. Biotechnol., 28(4), 1623-1632.

Singhal, A., Choudhary, G., Thakur, I.S. 2012. Characterization of laccase activity produced by Cryptococcus albidus. Preparative Biochemistry and Biotechnology, 42(2), 113-124.

Spina, F., Cordero, C., Schilirò, T., Sgorbini, B., Pignata, C., Gilli, G., Bicchi, C., Varese, G.C. 2015. Removal of micropollutants by fungal laccases in model solution and municipal wastewater: evaluation of estrogenic activity and ecotoxicity. J. Clean. Prod., 100, 185-194.

Suda, T., Hata, T., Kawai, S., Okamura, H., Nishida, T. 2012. Treatment of tetracycline antibiotics by laccase in the presence of 1-hydroxybenzotriazole. Bioresource technology, 103(1), 498-501.

Sun, K., Kang, F., Waigi, M.G., Gao, Y., Huang, Q. 2017. Laccase-mediated transformation of triclosan in aqueous solution with metal cations and humic acid. Environmental Pollution, 220, Part A, 105-111.

Suzuki, K., Hirai, H., Murata, H., Nishida, T. 2003. Removal of estrogenic activities of $17 \beta$-estradiol and ethinylestradiol by ligninolytic enzymes from white rot fungi. Water Research, 37(8), 1972-1975.

Thongkred, P., Lotrakul, P., Prasongsuk, S., Imai, T., Punnapayak, H. 2011. Oxidation of polycyclic aromatic hydrocarbons by a tropical isolate of Pycnoporus coccineus and its laccase. Scienceasia, 37, 225-233.

Tran, N.H., Urase, T., Kusakabe, O. 2010. Biodegradation characteristics of pharmaceutical substances by whole fungal culture Trametes versicolor and its laccase. J. water environ. technol., 8(2), 125140.

Wang, Z.-X., Cai, Y.-J., Liao, X.-R., Tao, G.-J., Li, Y.-Y., Zhang, F., Zhang, D.-B. 2010. Purification and characterization of two thermostable laccases with high cold adapted characteristics from Pycnoporus sp. SYBC-L1. Process Biochemistry, 45(10), 1720-1729.

Yang, S., Hai, F.I., Nghiem, L.D., Nguyen, L.N., Roddick, F., Price, W.E. 2013. Removal of bisphenol A and diclofenac by a novel fungal membrane bioreactor operated under non-sterile conditions. International Biodeterioration \& Biodegradation, 85, 483-490. 